
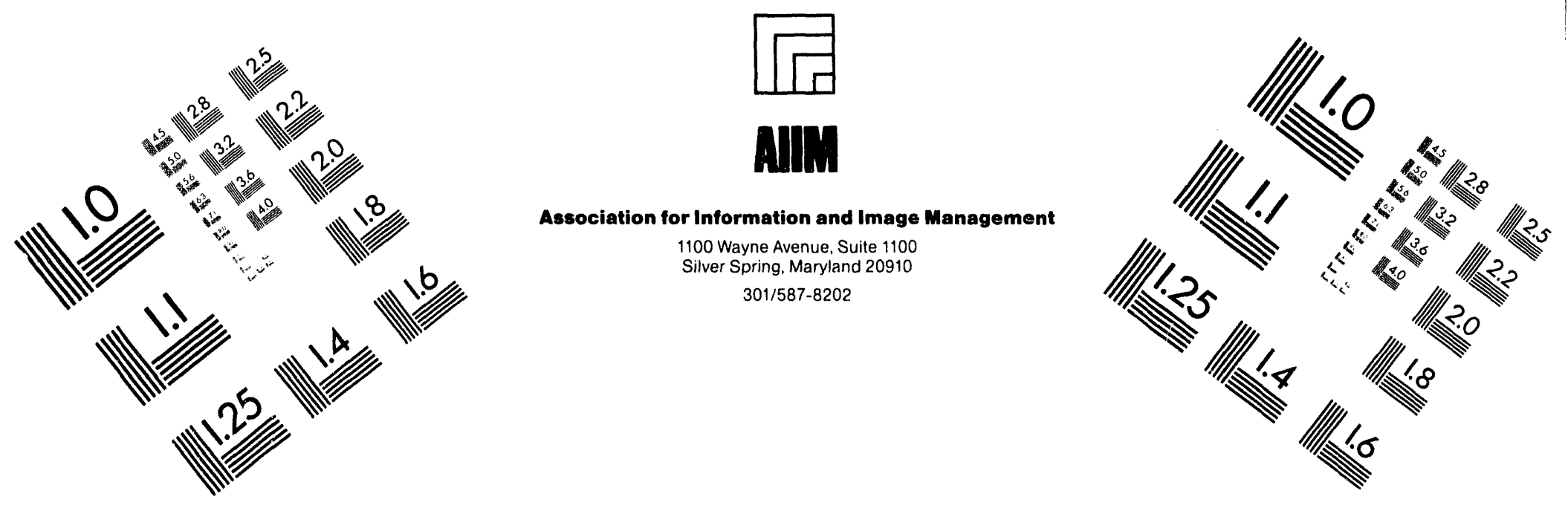

\title{
Centimeter
}

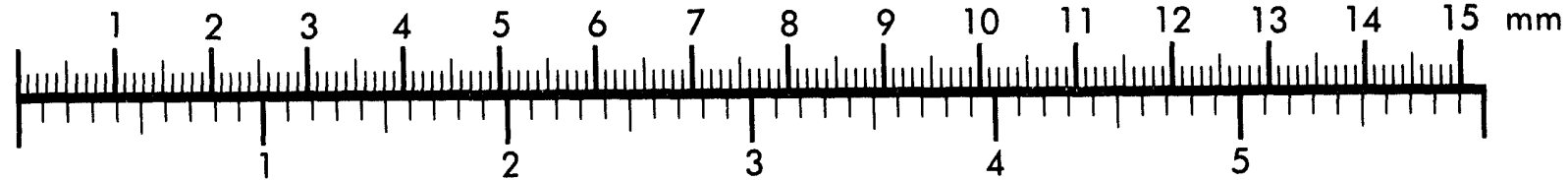

Inches
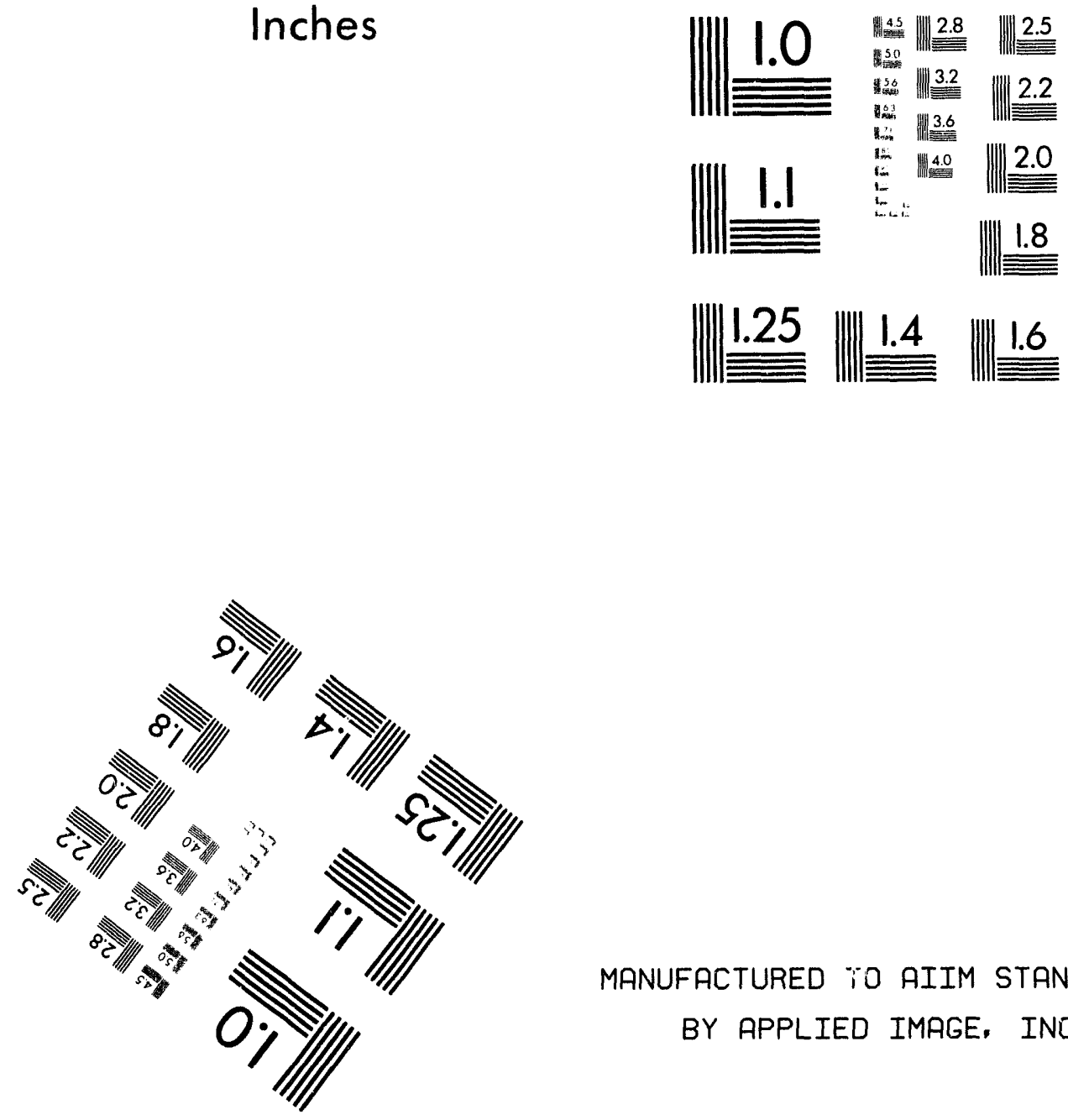

MANUFACTURED $T 0$ AIIM STANDARDS

BY APPLIED IMAGE, INC.

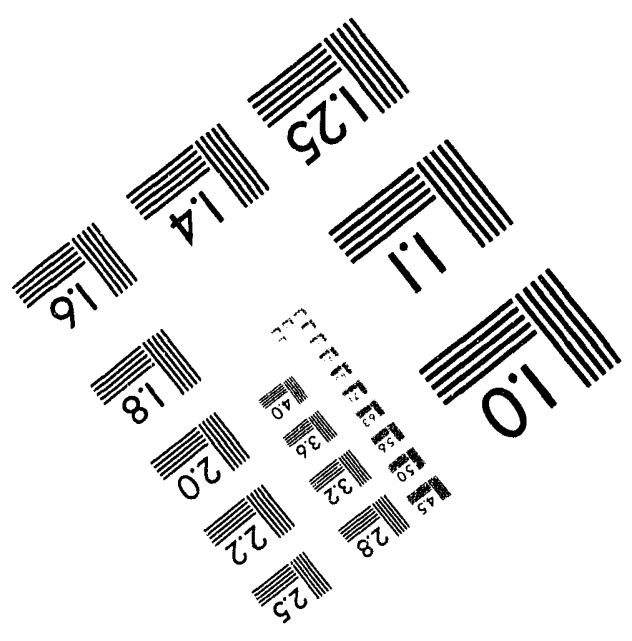



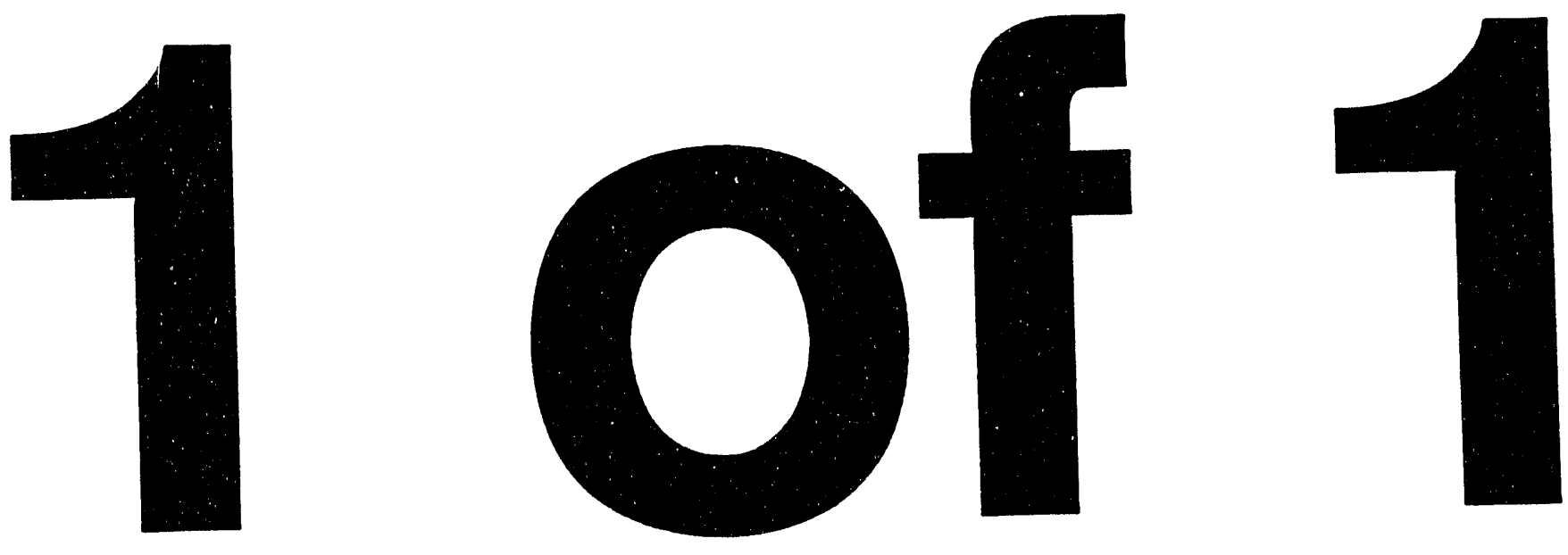
NUREG/CR-6181

PNL-9020

\section{A Pilot Application of Risk- \\ Based Methods to Establish In- \\ Service Inspection Priorities \\ for Nuclear Components at Surry \\ Unit 1 Nuclear Power Station}

Manuscript Completed: January 1994

Date Published: August 1994

Prepared by

T. Vo, B. Gore, F. Simonen, S. Doctor

Pacific Northwest Laboratory

Richland, WA 99352

Prepared for

Division of Engineering

Office of Nuclear Regulatory Research

U.S. Nuclear Regulatory Commission

Washington, DC 20555-0001

NRC FIN B2289 


\begin{abstract}
As part of the Nondestructive Evaluation Reliability Program sponsored by the U.S. Nuclear Regulatory Commission, the Pacific Northwest Laboratory is developing a method that uses risk-based approaches to establish inservice inspection plans for nuclear power plant components. This method uses probabilistic risk assessment (PRA) results and Failure Modes and Effects Analysis (FEMA) techniques to identify and prioritize the most risk-important systems and components for inspection. The Surry Nuclear Power Station Unit 1 was selected for pilot applications of this method. The specific systems addressed in this report are the reactor pressure vessel, the reactor coolant, the low-pressure injection, and the auxiliary feedwater. The results

provide a risk-based ranking of components within these systems and relate the target risk to target failure probability values for individual components. These results will be used to guide the development of improved inspection plans for nuclear power plants. To develop inspection plans, the acceptable level of risk from structural failure for important systems and components will be apportioned as a small fraction (i.e., 5\%) of the total PRA-estimated risk for core damage. This process will determine target (acceptable) risk and target failure probability values for individual components. Inspection requirements will be set at levels to assure that acceptable failure probabilities are maintained.
\end{abstract}




\section{Contents}

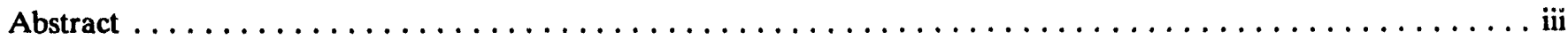

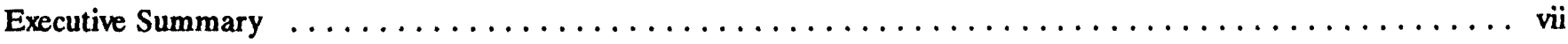

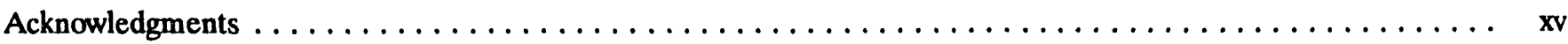

Acronyms $\ldots \ldots \ldots \ldots \ldots \ldots \ldots \ldots \ldots \ldots \ldots \ldots \ldots \ldots \ldots \ldots \ldots \ldots \ldots \ldots \ldots \ldots \ldots \ldots \ldots \ldots \ldots$

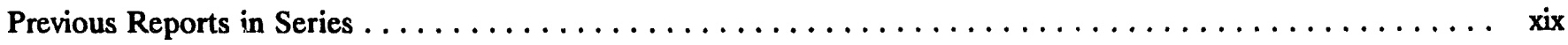

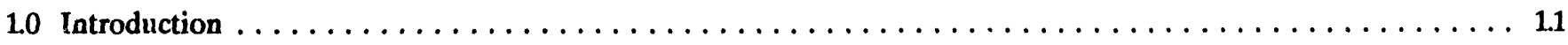

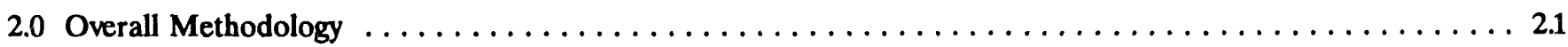

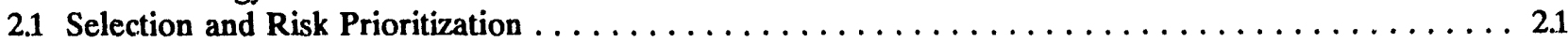

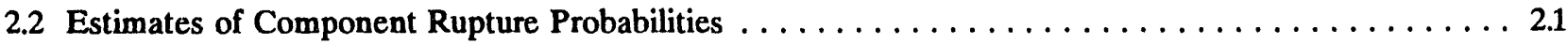

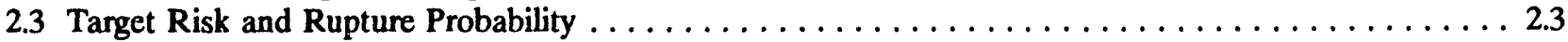

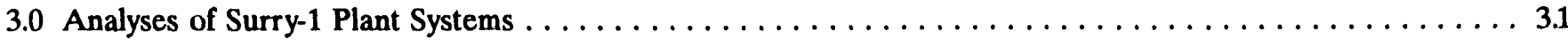

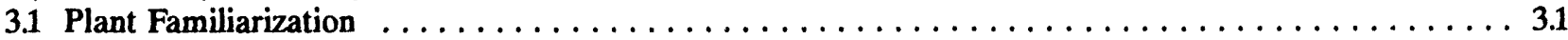

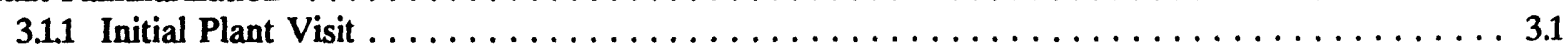

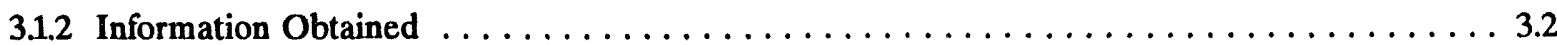

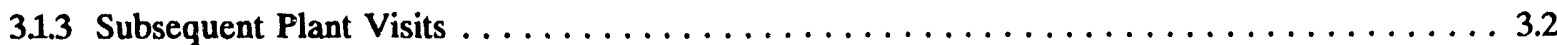

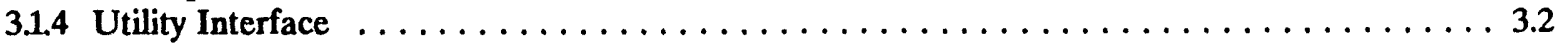

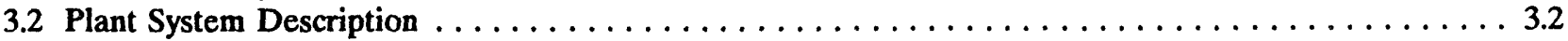

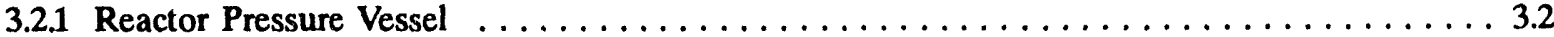

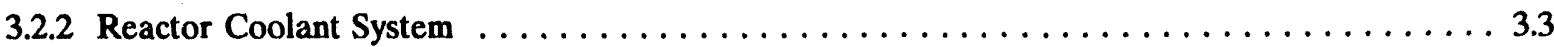

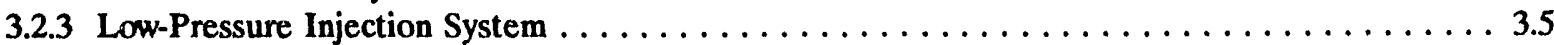

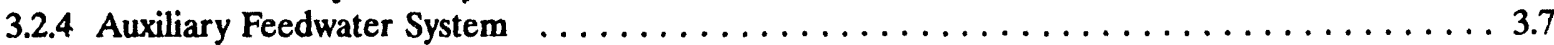

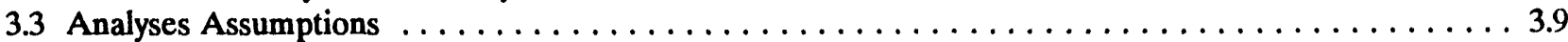

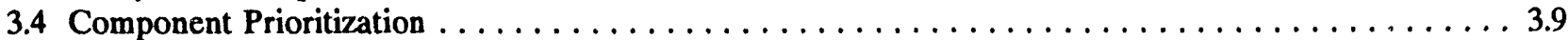

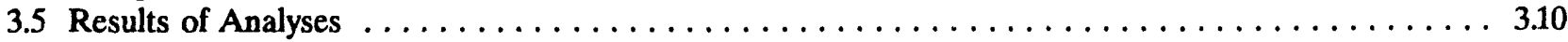

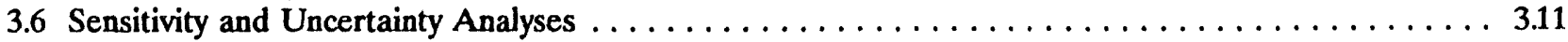

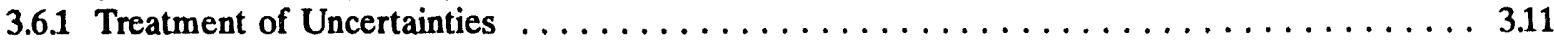

3.6.2 Results of Uncertainty/Sensitivity Analyses $\ldots \ldots \ldots \ldots \ldots \ldots \ldots \ldots \ldots \ldots \ldots \ldots \ldots \ldots \ldots \ldots \ldots$

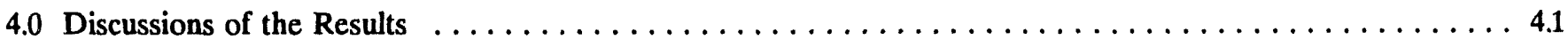

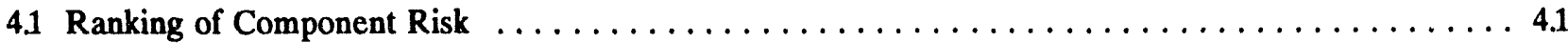

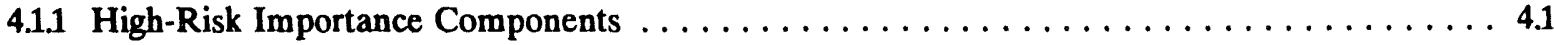

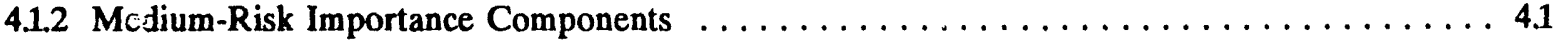

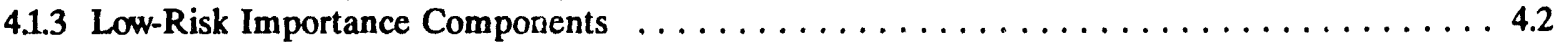

4.2 Development of Target Risk and Rupture Probability Values $\ldots \ldots \ldots \ldots \ldots \ldots \ldots \ldots \ldots \ldots .3$

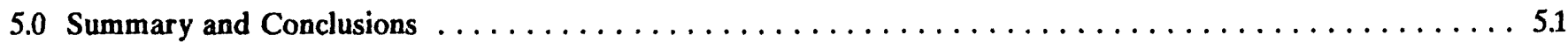

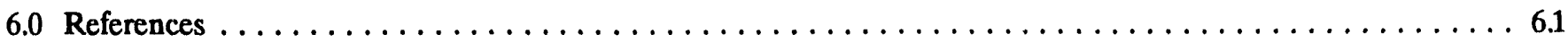

Appendix A: Sample of Component Importance Calculations $\ldots \ldots \ldots \ldots \ldots \ldots \ldots \ldots \ldots \ldots \ldots \ldots \ldots \ldots$ 


\section{Figures}

S.1. Risk Contributions of Surry-1 Components for the Four Systems Addressed by this Study . . . . . . . xi

S.2. Risk Contributions of Surry-1 Components Based on Conditional Core Damage Given a Component

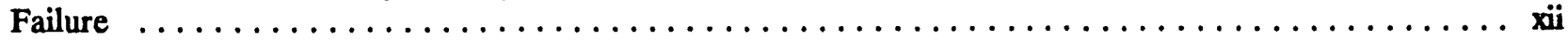

S.3. Cumulative Risk Contributions of Surry-1 Components $\ldots \ldots \ldots \ldots \ldots \ldots \ldots \ldots \ldots \ldots \ldots \ldots \ldots$

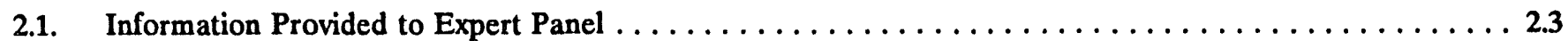

2.2. Estimates of Failure Probabilities for Surry-1 Reactor Pressure Vessel Components from Expert Judgement

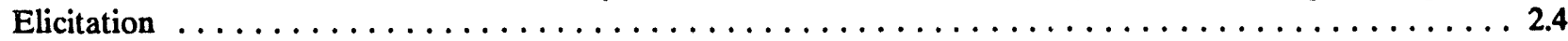

3.1. Surry-1 Reactor Pressure Vessel Simplified Schematic $\ldots \ldots \ldots \ldots \ldots \ldots \ldots \ldots \ldots \ldots \ldots \ldots \ldots$

3.2. Surry-1 Reactor Coolant System Simplified Schematic $\ldots \ldots \ldots \ldots \ldots \ldots \ldots \ldots \ldots \ldots \ldots \ldots \ldots$

3.3. Surry-1 Low-Pressure Injection/Recirculation System Simplified Schematic $\ldots \ldots \ldots \ldots \ldots \ldots$

3.4. Surry-1 Accumulator System Simplified Schematic $\ldots \ldots \ldots \ldots \ldots \ldots \ldots \ldots \ldots \ldots \ldots \ldots \ldots \ldots$

3.5. Surry-1 Auxiliary Feedwater System Simplified Schematic $\ldots \ldots \ldots \ldots \ldots \ldots \ldots \ldots \ldots \ldots \ldots$

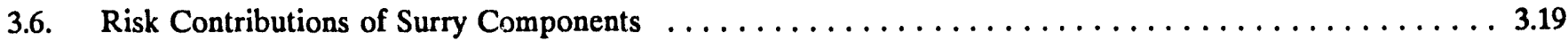

3.7. Cumulative Risk Contributions for Surry-1 Components $\ldots \ldots \ldots \ldots \ldots \ldots \ldots \ldots \ldots \ldots \ldots \ldots$

3.8. Risk Contribution of Surry Components Based on Conditional Core Damage Given the Rupture $\ldots \ldots 3.21$

\section{Tables}

S.1. Risk Importance Parameter for Surry-1 Components $\ldots \ldots \ldots \ldots \ldots \ldots \ldots \ldots \ldots \ldots \ldots \ldots \ldots$ ix

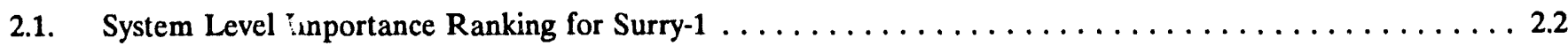

3.1. Component Rankings Based on Core Damage Frequency for Four Selected Systems at Surry-1 . . . . 3.13

3.2. Component Rankings Based on Conditional Core Damage Frequency Given a Component Rupture ${ }^{(a)}$

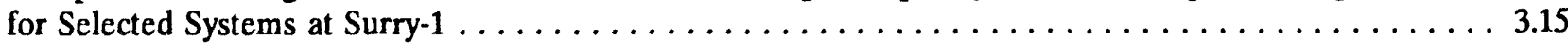

3.3. Risk Importance Parameters for Components at Selected Systems at Surry-1 $\ldots \ldots \ldots \ldots \ldots .17$

4.1. Component Importance Compared with ASME BPVC Section XI Classifications and ISI Requirements

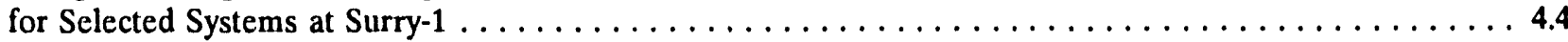




\section{Executive Summary}

As part of the Evaluation and Improvement of Nondestructive Evaluation (NDE) Reliability for Inservice Inspection of Light Water Reactors Program sponsored by the U.S. Nuclear Regulatory Commission (NRC), the Pacific Northwest Laboratory (PNL) has developed and applied a method using risk-based techniques to establish inservice inspection (ISI) plans for nuclear power plant components. As described in this report, the method uses probabilities of component failures (estimated by using an expert judgment clicitation process) and plant-specific probabilistic risk assessment (PRA) results in conjunction with the Failure Modes and Effects Analysis (FMEA) technique to establish ISI prioritics for systems and components. Included in this report is an approach for determining target risk and target rupture probability values for nuclear power plant components.

The Surry Nuclear Power Station Unit 1 (Surry-1) was selected for demonstrating the risk-based methodology. The specific systems addressed in this report are the reactor pressure vessel, reactor coolant, low-pressure injection including accumulators, and the auxiliary feedwater systems. The FMEAs were initially formulated using plant system drawings and other plant-specific information. The Standard Review Plan information developed by the NRC was used in determining the effects of system failures. To ensure that the plant models were as realistic as possible, visits at the Surry-1 plant were conducted for plant system walkdowns and discussions were held with plant operational and technical staff. Participation of Virginia Electric Power Company staff was an essential part of the pilot study.

Because of similarities in objeclives, the PNL program is coordinated with the American Society of Mechanical Engineers (ASME) Research Task Force on RiskBased Inspection Guidelines. This task force has made general recommendations on the application of riskbased methods to inservice inspection and will make specific proposals to ASME for improved codes and standards. Results of PNL studies are being made available to the ASME group to demonstrate and validate the usefulness of the risk-based concepts.

The results of the risk-based component prioritization are summarized in Figure S.1. For the purpose of comparison, the components were also ranked on the basis of a conditional probability of core damage given a component failure, as shown by Figure S.2.
Table S.1 shows the risk importance parameters for Surry-1 components. Included in the table are the estimated rupture probabilities for the component: of the systems analyzed.

On the basis of core damage frequency, contributions of component failure to core damage frequency range from about $1.6 \mathrm{E}-14$ to $1.58 \mathrm{E}-06$ per plant year. The cumulative risk contribution for all of the components considered was estimated to be about 2.1E-06 per plant year. Figure S.3 shows the results of cumulative risk contribution for Surry-1 components within the systems analyzed. This estimate is about 5\% of the total Surry PRA risk. The total estimated risk is dominated by failures of the reactor pressure vessel components $(86 \%$ of the total PRA risk). This risk is followed by the lowpressure injection system components (10\%), and then other various components within the auxiliary feedwater and reactor coolant systems (4\%). The results provide a guide to establish improved inspection priorities for nuclear power plant components.

To address uncertainties in the numerical results of the study, sensitivity analyses were performed. Based on uncertainties in estimated probabilities of component rupture probabilities, the sensitivity analyses results indicated no significant changes in component risk rankings (as shown in Figure S.1). Sensitivity analyses were also performed to determine overall core damage frequency duc to component failures by indirect effects (pipe whip, jet impingement effects, etc.). The results indicate that contributions to the overall core damage frequency from the indirect effects were negligible.

Included in the report is a comparison of the risk-based inspection priorities suggested by this study with the current Surry-1 plant ISI practices. ASME classifications and ISI requirements are generally in quantitative agreement with the risk-based rankings based on core damage frequency. The components making the greatest contribution to the core damage frequency have the most stringent ASME inspection requirements (i.e., both volumetric and surface examinations).

The analysis for the Surry-1 plant will be completed by developing the risk importance of components in the remaining systems (c.g., high-pressure injection, service water, and balance of plant). Similar plant-specific analyses will be performed for other pressurized-water reactors and for boiling-water reactors. Generic trends 
in component importance will be established from these plant-specific evaluations. Once the high-priority components have been identified, recommended inspection programs (method, frequency, and extent) will be developed. Probabilistic structural mechanics will be applied to establish inspection strategies that will ensure the component failure probabilities are maintained at acceptable levels.
To develop inspection plans, the acceptable level of risk from structural failures will be apportioned as a small fraction of the total PRA- estimated risk for core damage. This process will determine target (acceptable) risk and target failure probability values for individual components. Inspection requirements will be set at levels to assure that acceptable failure probabilities are maintained. 
Table S.1. Risk Importance Parameter for Surry-1 Components

\begin{tabular}{|c|c|c|c|c|}
\hline System-Component & Rank & $\begin{array}{l}\text { Conditional } \\
\text { Core Damage } \\
\text { Frequency } \\
\text { Given Rup- } \\
\text { ture }\end{array}$ & $\begin{array}{l}\text { Rupture } \\
\text { Frequency }\end{array}$ & $\begin{array}{c}\text { Core Dam- } \\
\text { age Fre- } \\
\text { quency }\end{array}$ \\
\hline RPV - Beltline Region Welds & 1 & 1.0 & $1.58 \mathrm{E}-06$ & $1.58 \mathrm{E}-06$ \\
\hline RPV - Beltline Plate & 2 & 1.0 & $1.00 \mathrm{E}-07$ & $1.00 \mathrm{E}-07$ \\
\hline RPV - Lower/Bottom Shell & 3 & 1.0 & 7.32E-08 & 7.32E-08 \\
\hline AFW - CST, Supply Line & 4 & $1.7 \mathrm{E}-02$ & 4.03E-06 & $6.86 \mathrm{E}-08$ \\
\hline $\begin{array}{l}\text { RPV - Circumferential Flange to Nozzle Course } \\
\text { Upper Shell, Outside Beltline Welds }\end{array}$ & 5 & 1.0 & $6.16 \mathrm{E}-08$ & $6.16 \mathrm{E}-08$ \\
\hline $\begin{array}{l}\text { LPI-A - Pipe Segment Between Accumulator Dis- } \\
\text { charge Header and RCS Isolation Valves }\end{array}$ & 6 & $1.8 \mathrm{E}-02$ & $2.59 \mathrm{E}-06$ & 4.67E-08 \\
\hline $\begin{array}{l}\text { LPI - Pipe Segment Between Containment Isolation } \\
\text { Valve (inside) and Cold Leg Injection }\end{array}$ & 7 & $3.2 \mathrm{E}-02$ & $1.30 \mathrm{E}-06$ & $4.16 \mathrm{E}-08$ \\
\hline $\begin{array}{l}\text { LPI - Pipe Segment Between Containment Isolation } \\
\text { Valve (inside) and Hot Leg Injection }\end{array}$ & 8 & $3.20 \mathrm{E}-02$ & $1.19 \mathrm{E}-06$ & $3.80 \mathrm{E}-08$ \\
\hline LPI - LPI Sources (RWST, Sump), Supply Line & 9 & $3.64 \mathrm{E}-02$ & $1.00 \mathrm{E}-06$ & $3.64 \mathrm{E}-08$ \\
\hline $\begin{array}{l}\text { LPI - Pipe Segment Between Pump Discharge and } \\
\text { Containment Isolation Valve }\end{array}$ & 10 & $3.2 \mathrm{E}-02$ & 8.63E-07 & $2.76 \mathrm{E}-08$ \\
\hline $\begin{array}{l}\text { LPI - Pipe Segment Between Containment Isolation } \\
\text { Valves }\end{array}$ & 11 & $1.6 \mathrm{E}-02$ & $9.13 \mathrm{E}-07$ & $1.46 \mathrm{E}-08$ \\
\hline RPV - CRDMs & 12 & $5.0 \mathrm{E}-04$ & $1.00 \mathrm{E}-05$ & $5.00 \mathrm{E}-09$ \\
\hline RPV - Instrument Lines & 13 & $5.0 \mathrm{E}-04$ & $1.00 \mathrm{E}-05$ & $5.00 \mathrm{E}-09$ \\
\hline $\begin{array}{l}\text { AFW - Pipe Segment Between Containment Isolation } \\
\text { and SG Isolation Valves }\end{array}$ & 14 & 8.49E-05 & $3.92 \mathrm{E}-05$ & $3.33 \mathrm{E}-09$ \\
\hline AFW - Main Steam to AFW Pump Turbine Drive & 15 & $1.64 \mathrm{E}-04$ & $1.28 \mathrm{E}-05$ & $2.10 \mathrm{E}-09$ \\
\hline $\begin{array}{l}\text { RCS - Pipe Segment Between Loop Stop Valve and } \\
\text { RPV (Cold Leg) }\end{array}$ & 16 & $1.13 \mathrm{E}-02$ & $1.42 \mathrm{E}-07$ & $1.60 \mathrm{E}-09$ \\
\hline LPI - LPI Pump Suction Line & 17 & $1.36 \mathrm{E}-03$ & $1.10 \mathrm{E}-06$ & $1.50 \mathrm{E}-09$ \\
\hline RCS - Pressurizer Spray Line & 18 & $1.0 \mathrm{E}-04$ & $1.00 \mathrm{E}-05$ & $1.00 \mathrm{E}-09$ \\
\hline $\begin{array}{l}\text { RCS - Pipe Segment Between RPV and Loop Stop } \\
\text { Valve (Hot Leg) }\end{array}$ & 19 & $2.86 \mathrm{E}-03$ & $2.00 \mathrm{E}-07$ & $5.72 \mathrm{E}-10$ \\
\hline
\end{tabular}


Table S.1 (cont'd)

\begin{tabular}{|c|c|c|c|c|}
\hline System-Componeni & Rank & $\begin{array}{c}\text { Conditional } \\
\text { Core Damage } \\
\text { Frequency } \\
\text { Given Rup- } \\
\text { ture } \\
\end{array}$ & $\begin{array}{l}\text { Rupture } \\
\text { Frequency }\end{array}$ & $\begin{array}{c}\text { Core Dam- } \\
\text { age Fre- } \\
\text { quency }\end{array}$ \\
\hline AFW - AFW TD Pump Discharge Line & 20 & $5.2 \mathrm{E}-05$ & $1.02 \mathrm{E}-05$ & $5.26 \mathrm{E}-10$ \\
\hline AFW - Pipe Segment from Unit 2 AFW Pumps & 21 & $1.4 \mathrm{E}-04$ & $2.98 \mathrm{E}-06$ & 4.18E-10 \\
\hline AFW - AFW Isolation Valve to SG & 22 & $2.46 \mathrm{E}-06$ & $6.51 \mathrm{E}-05$ & $1.60 \mathrm{E}-10$ \\
\hline RPV - Nozzle to Vessel Welds & 23 & $3.0 \mathrm{E}-03$ & $2.00 \mathrm{E}-08$ & $6.00 \mathrm{E}-11$ \\
\hline RPV - Vessel Studs & 24 & $5.0 \mathrm{E}-04$ & $1.00 \mathrm{E}-07$ & $5.00 \mathrm{E}-11$ \\
\hline AFW - AFW MDP Suction Line & 25 & $1.2 \mathrm{E}-05$ & $3.55 \mathrm{E}-06$ & $4.27 \mathrm{E}-11$ \\
\hline AFW - AFW MDP Discharge Line & 26 & $1.65 \mathrm{E}-05$ & 2.39E-06 & $3.95 \mathrm{E}-11$ \\
\hline RPV - Upper, Closure Head, Flange & 27 & $1.79 \mathrm{E}-03$ & $2.00 \mathrm{E}-08$ & $3.58 \mathrm{E}-11$ \\
\hline RPV - Nozzle Forging Inlet/Outlet & 28 & $1.25 \mathrm{E}-03$ & $2.00 \mathrm{E}-08$ & $2.50 \mathrm{E}-11$ \\
\hline AFW - AFW TDP Suction Line & 29 & $2.47 \mathrm{E}-06$ & $6.12 \mathrm{E}-06$ & $1.51 \mathrm{E}-11$ \\
\hline $\begin{array}{l}\text { AFW' - Pipe Segment from Emergency Makeup } \\
\text { System, Fire Main }\end{array}$ & 30 & $3.9 \mathrm{E}-06$ & $1.46 \mathrm{E}-06$ & $5.71 \mathrm{E}-12$ \\
\hline RCS - Pressurizer Relief/Safety Line & 31 & $3.53 \mathrm{E}-07$ & $6.14 \mathrm{E}-06$ & $2.26 \mathrm{E}-12$ \\
\hline RCS - Pressurizer Surge Line & 32 & $1.5 \mathrm{E}-06$ & $6.1 \mathrm{E}-07$ & 9.15E-13 \\
\hline LPI-A - Accumulator Discharge Line & 33 & $3.5 \mathrm{E}-08$ & $2.0 \mathrm{E}-07$ & $9.09 \mathrm{E}-14$ \\
\hline RCS - Pipe Segment Between SG and RCP & 34 & $3.05 \mathrm{E}-07$ & $2.0 \mathrm{E}-07$ & $6.10 \mathrm{E}-14$ \\
\hline $\begin{array}{l}\text { RCS - Pipe Segment Between Loop Stop Valve and } \\
\text { SG (Hot Leg) }\end{array}$ & 35 & $3.05 \mathrm{E}-07$ & $1.41 \mathrm{E}-07$ & $4.30 \mathrm{E}-14$ \\
\hline $\begin{array}{l}\text { RCS - Pipe Segment Betwcen RCP and Loop Stop } \\
\text { Valve (Cold Leg) }\end{array}$ & 36 & 3.05E-07 & $7.75 \mathrm{E}-08$ & $2.36 \mathrm{E}-14$ \\
\hline LPI-A - Accumulator, Suction Line & 37 & $3.5 \mathrm{E}-08$ & 4.57E-07 & $1.60 \mathrm{E}-14$ \\
\hline
\end{tabular}


เ8เ9-ชว/องบกN

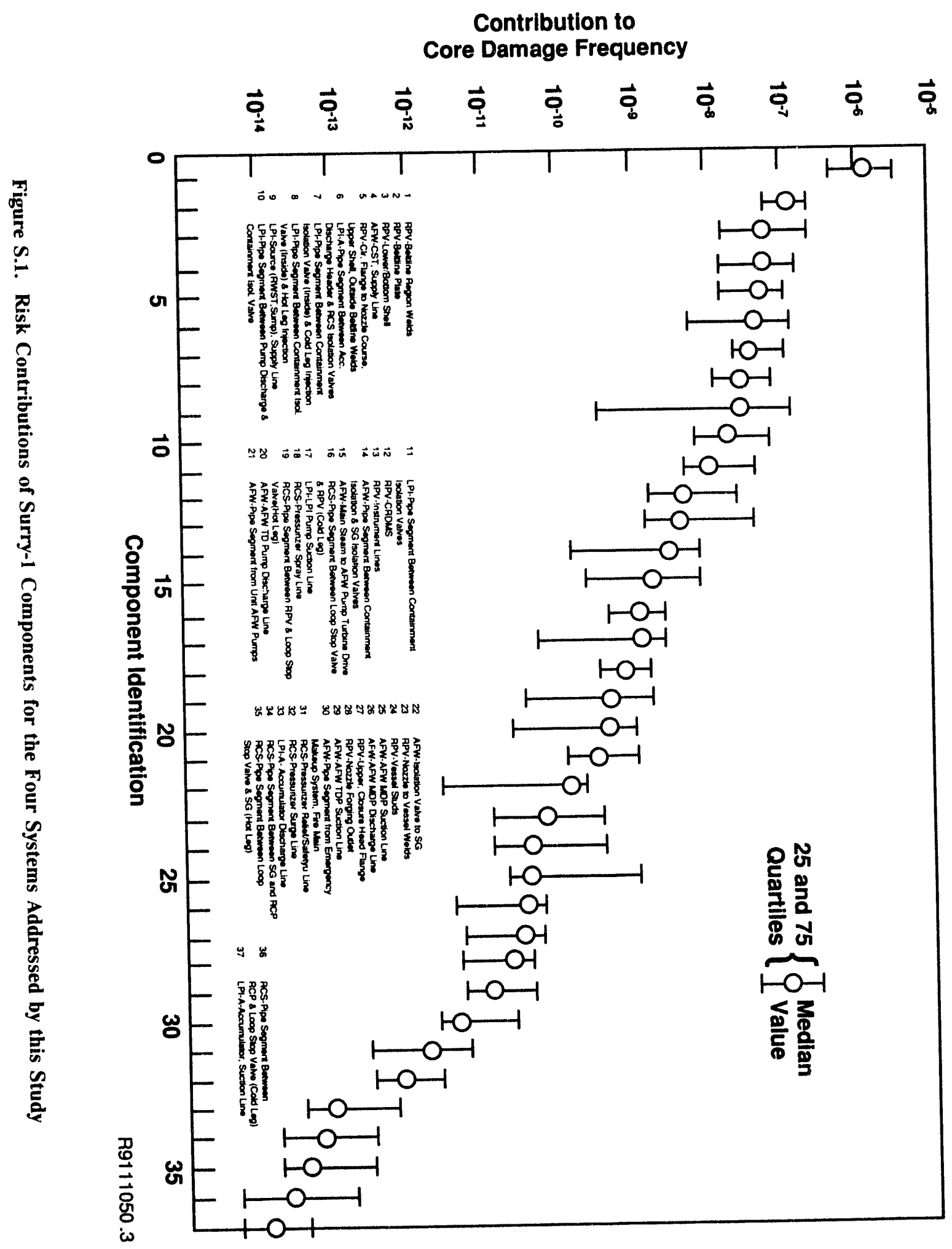




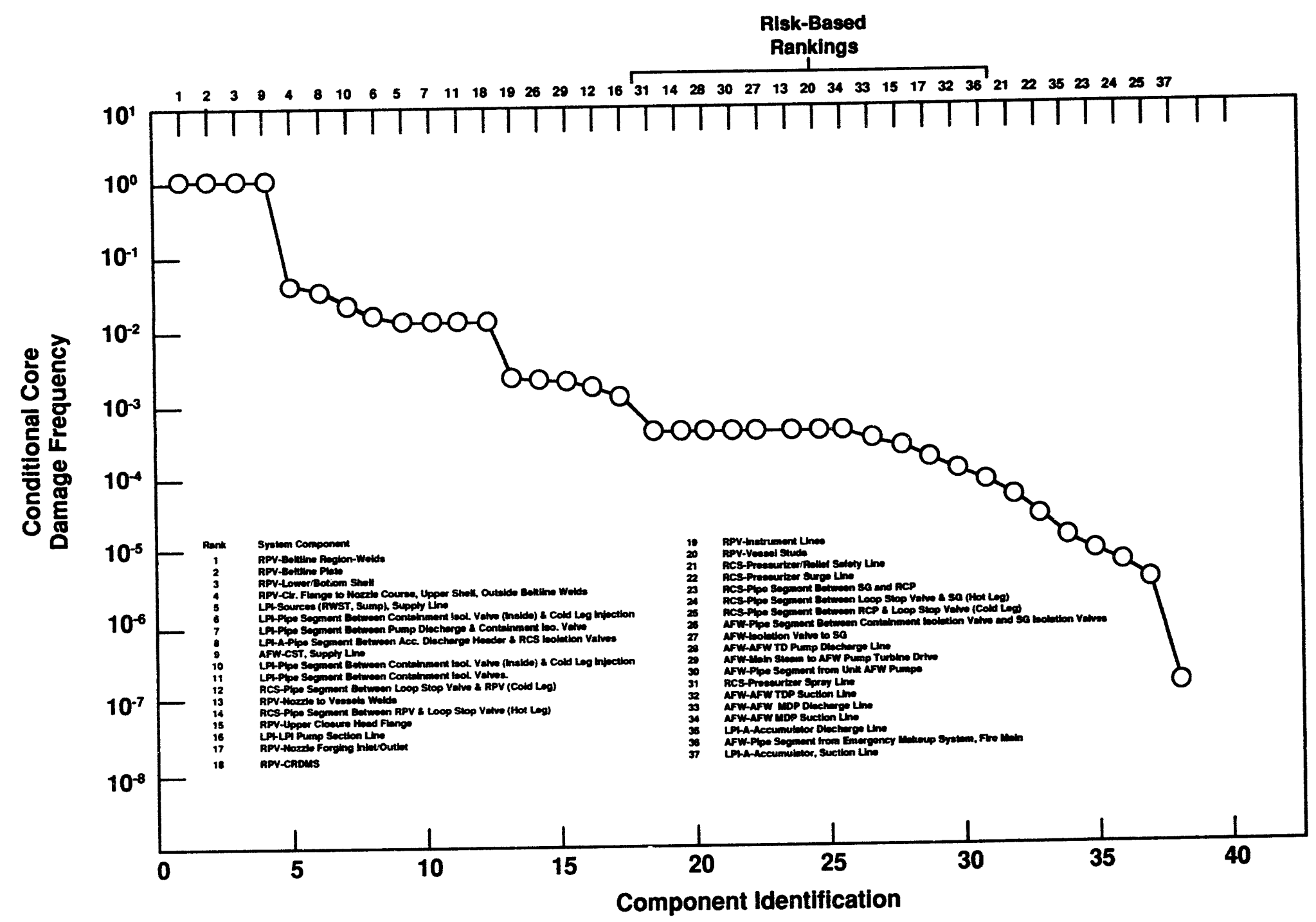

R9111050.4

Figure S.2. Risk Contributions of Surry-1 Components Based on Conditional Core Damage Given a Component Failure 


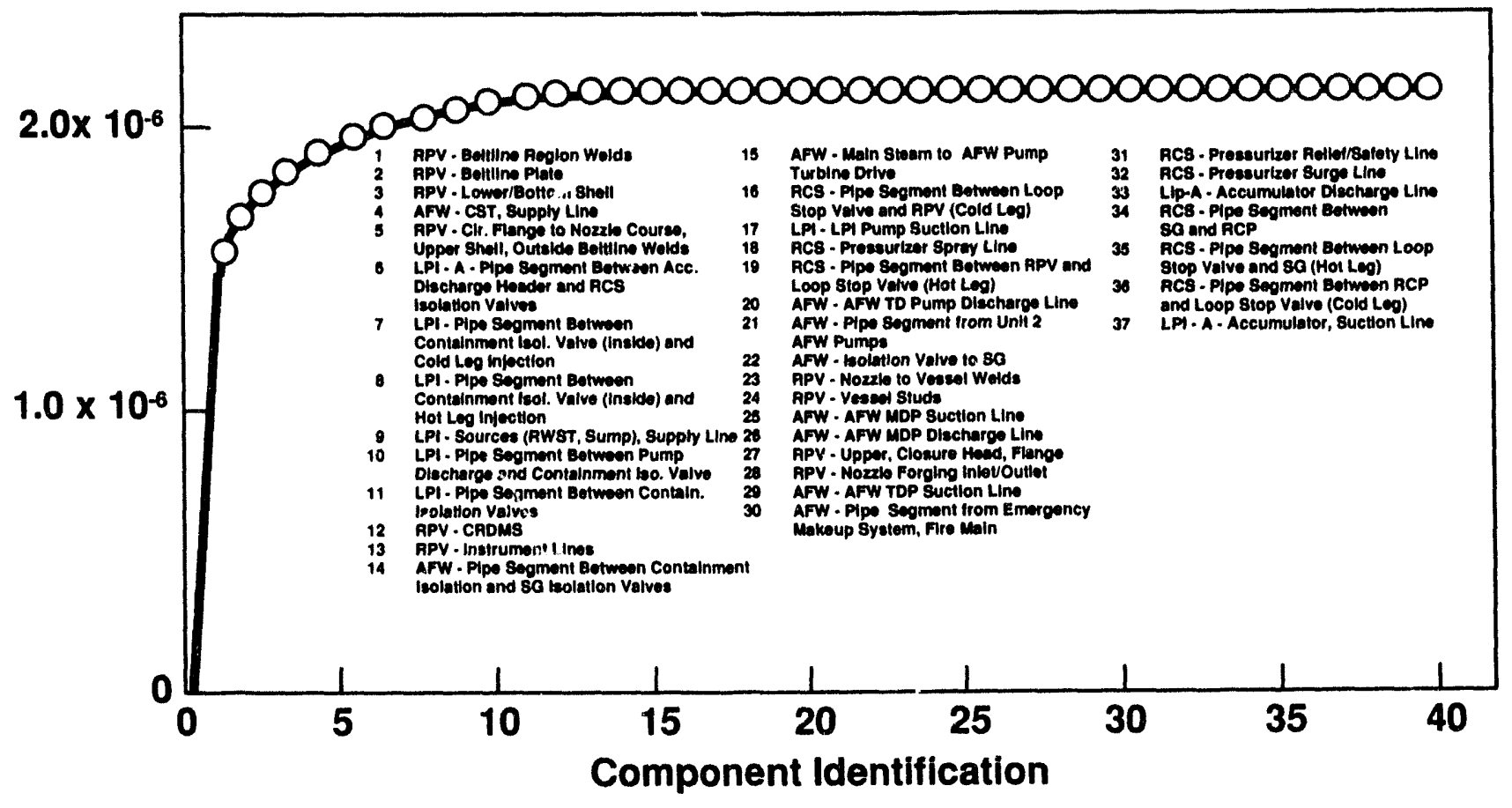

R9108092.4

Figure S.3. Cumulative Risk Contributions of Surry-1 Components 


\section{Acknowledgments}

This work was supported by the U.S. Nuclear Regulatory Commission (NRC) under a Related Service Agreement with the U.S. Department of Energy under contract DE-ACO6-76RLO 1830. The authors wish to acknowledge the direction and support provided by Dr. Joe Muscara, NRC Program Manager. Dr. L. R.

Abramson from the NRC staff provided guidance to the elicitation process. Acknowledgments are also addressed to the many Virginia Electric Power Company staff for their participation in this work, particularly Ms. C. G. Lovett, Mr. R. K. MacManus, Mr. A.

McNeil, Mr. D. Rogers, Mr. D. Sommers, and Mr. E. W. Throckmorton. The authors wish to thank T. T. Taylor, B. W. Smith, and T. W. Bardell for their contributions and review of this work. 


\section{Acronyms}

AFW
ASME
ASTM
BPVC
BWR
CRDM
FMEA
FSAR
IRRAS
ISI
LOCA
LPI
LPI/LPR
MDP
MOV
NDE
NRC
P\&ID
PNL
PRA
PWR
RCP
RCS
RPV
RWST
SG
TDP
VEPCO
VIMS

\author{
Auxiliary Feedwater System \\ American Society of Mechanical Engineers \\ American Society of Testing and Materials \\ Boiler and Pressure Vessel Code \\ Boiling Water Reactor \\ Control Rod Driven Mechanisms \\ Failure Modes and Effects Analysis \\ Final Safety Analysis Report \\ Integrated Reliability and Risk Analysis System \\ Inservice Inspection \\ Loss of Coolant Accident \\ Low Pressure Injection System \\ Low Pressure Injection/Recirculation System \\ Motor Driven Pump \\ Motor-Operated Valves \\ Nondestructive Evaluation \\ U.S. Nuclear Regulatory Commission \\ Piping and Instrumentation Diagram \\ Pacific Northwest Laboratory \\ Probabilistic Risk Assessment \\ Pressurized Water Reactor \\ Reactor Coolant Pump \\ Reactor Coolant System \\ Reactor Pressure Vessel \\ Reactor Water Storage Tank \\ Steam Generator \\ Turbine Driven Pump \\ Virginia Electric Power Company \\ Video Information Management System
}




\section{Previous Reports in Series}

Doctor, S. R., A. A. Diaz, J. R. Friley, M. S. Good, M. S. Greenwood, P. G. Heasler, R. L. Hockey, R. J. Kurtz, F. A. Simonen, J. C. Spanner, T. T. Taylor, and T. V. Vo. 1993. Nondestructive Examination (NDE) Reliability for Inservice Inspection of Light Water Reactors. NUREG/CR-4469, PNL-5711, Vol. 15. Pacific Northwest Laboratory, Richland, Washington.

Doctor, S. R., A. A. Diaz, J. R. Friley, M. S. Good, M. S. Greenwood, P. G. Heasler, R. L. Hockey, R. J. Kurtz, F. A. Simonen, J. C. Spanner, T. T. Taylor, and T. V. Vo. 1992. Nondestructive Examination (NDE) Reliability for Inservice Inspection of Light Water Reactors. NUREG/CR-4469, PNL-5711, Vol. 14. Pacific Northwest Laboratory, Richland, Washington.

Green, E. R., S. R. Doctor, R. L. Hockey, and A. A. Diaz. 1992. Development of Equipment Parameter Tolerances for the Uttrasonic Inspection of Steel Components: Application to Components up to 3 Inches Thick. NUREG/CR-5817, Vol 1. Pacific Northwest Laboratory, Richland, Washington.

Green, E. R., S. R. Doctor, R. L. Hockey, and A. A. Diaz. The Interaction Matrix Study: Models and Equipment Sensitivity Studies for the Ultrasonic Inspection of Thin Wall Steel. NUREG/CR-5817. Pacific Northwest Laboratory, Richland, Washington.

Doctor, S. R., M. S. Good, P. G. Heasler, R. L. Hockey, F. A. Simonen, J. C. Spanner, T. T. Taylor, and T. V. Vo. 1992. Nondestructive Examination (NDE) Reliability for Inservice Inspection of Light Water Reactors. NUREG/CR-4469, PNL-5711, Vol. 13. Pacific Northwest Laboratory, Richland, Washington.

Doctor, S. R., M. S. Good, P. G. Heasler, R. L. Hockey, F. A. Simonen, J. C. Spanner, T. T. Taylor, and T. V. Vo. 1992. Nondestructive Examination (NDE) Reliability for Inservice Inspection of Light Water Reactors. NUREG/CR-4469, PNL-5711, Vol. 12. Pacific Northwest Laboratory, Richland, Washington.

Doctor, S. R., M. S. Good, E. R. Green, P. G. Heasler, F. A. Simonen, J. C. Spanner, T. T. Taylor, and T. V. Vo. 1991. Nondestructive Examination (NDE) Reliability for Inservice Inspection of Light Water Reactors. NUREG/CR-4469, PNL-5711, Vol. 11. Pacific Northwest Laboratory, Richland, Washington.
Heasler, P. G., T. T. Taylor, J. C. Spanner, S. R. Doctor, and J. D. Deffenbaugh. 1990. Ultrasonic Inspection Reliability for Intengranular Stress Corrosion Cracks: $A$ Rov' id Robin Study of the Effects of Personnel, Procedures, Equipment and Crack Characteristics.

NUREG/CR-4908. Pacific Northwest Laboratory, Richland, Washington.

Spanner, J. C., S. R. Doctor, T. T. Taylor/PNL and J. Muscara/NRC. 1990. Qualification Process for Ultrasonic Testing in Nuclear Inservice Inspection Applications. NUREG/CR-4882, PNL-6179. Pacific Northwest Laboratory, Richland, Washington.

Doctor, S. R., J. D. Deffenbaugh, M. S. Good, E. R. Green, P. G. Heasler, F. A. Simonen, J. C. Spanner, T. T. Taylor, and T. V. Vo. 1990. Nondestructive Examination (NDE) Reliability for Inservice Inspection of Light Water Reactors. NUREG/CR-4469, PNL-5711, Vol. 10. Pacific Northwest Laboratory, Richland, Washington.

Doctor, S. R., J. D. Deffenbaugh, M. S. Good, E. R. Green, P. G. Heasler, F. A. Simonen, J. C. Spanner, and T. T. Taylor. 1989. Nondestructive Examination (NDE) Reliability for Inservice Inspection of Light Water Reactors. NUREG/CR-4469, PNL-5711, Vol. 9. Pacific Northwest Laboratory, Richland, Washington.

Doctor, S. R., J. D. Deffenbaugh, M. S. Good, E. R. Green, P. G. Heasler, F. A. Simonen, J. C. Spanner, and T. T. Taylor. 1989. Nondestnuctive Examination (NDE) Reliability for Inservice Inspection of Light Water Reactors. NUREG/CR-4469, PNL-5711, Vol. 8. Pacific Northwest Laboratory, Richland, Washington.

Doctor, S. R., J. D. Deffenbaugh, M. S. Good, E. R. Green, P. G. Heasler, F. A. Simonen, J. C. Spanner, and T. T. Taylor. 1988. Nondestructive Examination (NDE) Reliability for Inservice Inspection of Light Water Reactors. NUREG/CR-4469, PNL-5711, Vol. 7. Pacific Northwest Laboratory, Richland, Washington.

Doctor, S. R., J. D. Deffenbaugh, M. S. Good, E. R. Green, P. G. Heasler, G. A. Mart, F. A. Simonen, J. C. Spanner, T. T. Taylor, and L. G. Van Fleet. 1987. Nondestructive Examination (NDE) Reliability for Inservice Inspection of Light Water Reactors. NUREG/CR4469, PNL-5711, Vol. 6. Pacific Northwest Laboratory, Richland, Washington. 
Doctor, S. R., D. J. Bates, J. D. Deffenbaugh, M. S. Good, P. G. Heasler, G. A. Mart, F. A. Simonen, J. C. Spanner, T. T. Taylor, and L. G. Van Fleet. 1987. Nondestructive Examination (NDE) Reliability for Inservice Inspection of Light Water Reactors. NUREG/CR4469, PNL-5711, Vol. 5. Pacific Northwest Laboratory, Richland, Washington.

Doctor, S. R., D. J. Bates, J. D. Deffenbaugh, M. S. Good, P. G. Heasler, G. A. Mart, F. A. Simonen, J. C. Spanner, A. S. Tabatabai, T. T. Taylor, and L. G. Van Fleet. 1987. Nondestructive Examination (NDE) Reliability for Inservice Inspection of Light Water Reactors. NUREG/CR-4469, PNL-5711, Vol. 4. Pacific Northwest Laboratory, Richland, Washington.

Collins, H. D. and R. P. Gribble. 1986. Siamese Imaging Technique for Quasi-Vertical Type (QVT) Defects in Nuclear Reactor Piping. NUREG/CR-4472, PNL-5717. Pacific Northwest Laboratory, Richland, Washington.

Doctor, S. R., D. J. Bates, R. L. Bickford, L. A. Charlot, J. D. Deffenbaugh, M. S. Good, P. G. Heasler, G. A. Mart, F. A. Simonen, J. C. Spanner, A. S. Tabatabai, T. T. Taylor, and L. G. Van Fleet. 1986. Nondestructive Examination (NDE) Reliability for Inservice Inspection of Light Water Reactors. NUREG/CR4469, PNL-5711, Vol. 3. Pacific Northwest Laboratory, Richland, Washington.

Doctor, S. R., D. J. Bates, L. A. Charlot, M. S. Good, H. R. Hartzog, P. G. Heasler, G. A. Mart, F. A. Simonen, J. C. Spanner, A. S. Tabatabai, and T. T. Taylor. 1986. Evaluation and Iimprovement of NDE Reliability for Inservice Inspection of Light Water Reactors. NUREG/CR-4469, PNL-5711, Vol. 2. Pacific Northwest Laboratory, Richland, Washington.

Doctor, S. R., D. J. Bates, L. A. Charlot, H. D. Collins, M. S. Good, H. R. Hartzog, P. G. Heasler, G. A. Mart, F. A. Simonen, J. C. Spanner, and T. T. Taylor. 1986. Integration of Nondestructive Examination (NDE) Reliability and Fracture Mechanics, Semi-Annual Report, April 1984 - September 1984. NUREG/CR-4469, PNL 5711, Vol. 1. Pacific Northwest Laboratory, Richland, Washington.
Good, M. S. and L. G. Van Fleet. 1986. Status of Activities for Inspecting Weld Overlaid Pipe Joints. NUREG/CR-4484, PNL-5729. Pacific Northwest Laboratory, Richland, Washington.

Heasler, P. G., D. J. Bates, T. T. Taylor, and S. R. Doctor. 1986. Performance Demonstration Tests for Detection of Intengranular Stress Corrosion Cracking. NUREG/CR-4464, PNL-5705, Pacific Northwest Laboratory, Richland, Washington.

Simonen, F. A. 1984. The Impact of Nondestructive Examination Unreliability on Pressure Vessel Fracture Predictions. NUREG/CR-3743, PNL-5062. Pacific Northwest Laboratory, Richland, Washington.

Simonen, F. A. and H. H. Woo. 1984. Analyses of the Impact of Inservice Inspection Using Piping Reliability Model. NUREG/CR-3869, PNL-5149. Pacific Northwest Laboratory, Richland, Washington.

Taylor, T. T. 1984. An Evaluation of Manual Ultrasonic Inspection of Cast Stainless Steel Piping. NUREG/CR-3753, PNL-5070. Pacific Northwest Laboratory, Richland, Washington.

Bush, S. H. 1983. Reliability of Nondestructive Examination, Volumes I, II, and III. NUREG/CR-3110-1, -2, and -3; PNL-4584. Pacific Northwest Laboratory, Richland, Washington.

Simonen, F. A. and C. W. Goodrich. 1983. Parametric Calculations of Fatigue Crack Growth in Piping. NUREG/CR-3059, PNL-4537. Pacific Northwest Laboratory, Richland, Washington.

Simonen, F. A., M. E. Mayfield, T. P. Forte, and D. Jones. 1983. Crack Growth Evaluation for Small Cracks in Reactor-Coolant Piping. NUREG/CR-3176, PNL-4642. Pacific Northwest Laboratory, Richland, Washington.

Taylur, T. T., S. L. Crawford, S. R. Doctor, and G. J. Posai ony. 1983. Detection of Small-Sized Near-Surface Unde -Cl'ai Crucks for Reactor Pressure Vessels. NUREG/CR-2878, PNL-4373. Pacific Northwest Laboratory, Richland, Washington. 
Busse, L. J., F. L. Becker, R. E. Bowey, S. R. Doctor, R. P. Gribble, and G. J. Posakony. 1982. Characterization Methods for Ultrasonic Test Systems.

NUTREG/CR-2264, PNL-4215. Pacific Northwest Laboratory, Richland, Washington.

Morris, C. J. and F. L. Becker. 1982. State-of-Practice Review of Ultrasonic In-senvice Inspection of Class I System Piping in Commercial Nuclear Power Plants. NUREG/CR-2468, PNL-4026. Pacific Northwest Laboratory, Richland, Washington.
Becker, F. L., S. R. Doctor, P. G. Heasler, C. J. Morris, S. G. Pitman, G. P. Selby, and F. A. Simonen. 1981. Integration of NDE Reliability and Fracture Mechanics, Phase I Report. NUREG/CR-1696-1, PNL-3469. Pacific Northwest Laboratory, Richland, Washington.

Taylor, T. T. and G. P. Selby. 1981. Evaluation of ASME Section XI Reference Level Sensitivity for Initiation of Ultrasonic Inspection Examination.

NUREG/CR-1957, PNL-3692. Pacific Northwest Laboratory, Richland, Washington. 


\subsection{Introduction}

Pacific Northwest Laboratory (PNL) is conducting a multi-year program for the U.S. Nuclear Regulatory Commission (NRC) entitled "Evaluation and Improvement in Nondestructive Evaluation Reliability for Inservice Inspection (ISI) of Light Water Reactors". The goals of this program ase to determine the reliability of current ISI of pressure boundary systems and components, and to develop recommendations that can ensure high inspection reliability. The long-term objective is to develop technical bases for improvements to the inspection requirements of nuclear power plant components.

Because of similarities in objectives, the PNL program is coordinated with the American Society of Mechanical Engineers (ASME) Research Task Force on RiskBased Inspection Guidelines. The initial task force document (ASME 1991) has made general recommendations on the application of risk-based methods to ISI, and forms the basis of future proposals to ASME for improved codes and standards. Results of PNL studies are being made available to the ASME group to demonstrate and validate the usefulness of the risk-based methodology. Future documents specifically addressing nuclear power plant components will be issued by the ASME Task Force.

To provide technical bases for improved ISI plans, PNL has developed and applied a method (Vo et al. 1989) that uses results of probabilistic risk assessments (PRAs) to estimate the consequences of component failures. The probabilities of these component failures have been estimated by using an expert judgment elicitation process (Vo et al. 1991). Using these estimates of consequences and probabilities, risk calculations have established ISI priorities for systems and components at nuclear power plants. Once high-priority components have been identified, recommended inspection programs (method, frequency, and extent) will be developed in future work. Probabilistic structural mechanics will be applied to establish inspection strategies that will ensure that component failure rates are maintained at acceptable levels. After candidate inspection strategies yielding component failure probabilities less than identified target values have been determined, decision analysis techniques can be used to identify optimum inspection strategies.
This report describes evaluations for the Surry Nuclear Power Station Unit 1 (Surry-1) which was selected for demonstrating the risk-based methodology. Participation of Virginia Electric Power Company (VEPCO) staff was an essential part of the pilot study. Plantspecific information was obtained through system drawings, visits to the plant site, and discussions with plant operational staff. The specific systems selected for study were the reactor pressure vessel, reactor coolant, low-pressure injection including accumulators, and the auxiliary feedwater systems. The remaining pressure boundary systems at Surry-1 will be addressed in a future report. This report presents the results for the most risk-important components within the four selected systems at Surry-1 and compares the results for ISI prioritics with the current ISI practices. Differences are being assessed to determine the extent of potential improvements to ISI plans provided by the new methodology.

Section 2.0 of this report discusses the overall methodology for risk-based ranking of systems and components. Part of this discussion addresses the methods used to estimate component rupture probabilities. An approach is proposed for setting target values for these rupture probabilitics at suitable levels. The objective of this approach is to ensure that the contribution of pressure boundary failures to core damage risk remains a small fraction of total plant risk.

Section 3.0 provides details of the Surry-1 pilot study. Descriptions are provided for the four systems addressed, and the assumptions made in the analyses are also included. Results of the component rankings as well the sensitivity and uncertainty analyses are presented. Section 4.0 provides a detailed discussion and interpretation of the resuits of Section 3.0. Finally, a summary and conclusions of the study are presented in Section 5.0 . 


\subsection{Overall Methodology}

The overall methodology has three major steps: 1) selection and risk-prioritization of systems and components for inspection, 2) selection of a total target risk value associated with all pressure boundary and structural failures, and 3) determination of target rupture probability for individual components or structures. The following subsections summarize the overall methodology.

\subsection{Selection and Risk Prioritization}

Both the Inspection Importance Measure $\left(I^{\mathrm{w}}\right)$ developed by PNL (Vo et al. 1989) and the Failure Modes and Effects Analysis (FMEA) technique were used to identify and prioritize the most risk-important systems and components for inspection. Previous work at PNL has addressed priorities at a system level as a prelude to component level prioritization. In summary, for a given system, $I^{\mathrm{W}}$ is defined as the product of the Birnbaum Importance $\left(\mathrm{I}^{\mathrm{B}}\right)$ times the failure probability for that system.

$$
I^{W}=I^{B} * P_{f}
$$

where $I^{B}=$ the change in risk that is associated with a system failure

$P_{f}=$ system failure probability due to structural integrity failures.

Core-damage frequency (Level-I PRA) was used in this study as the bottom-line risk measure to prioritize the plant systems. When risk is measured by core damage frequency, the $I^{B}$ of a system is equivalent to the conditional probability of core damage given a system failure. The parameter $I^{B}$ is a measure of the consequence of structural failure, where $\mathrm{I}^{\mathrm{w}}$ also addresses the probabilities of structural failures. Specifically, $I^{\mathrm{W}}$ is an approximation of the core damage risk due to system failures caused by structural failures. Components with very high $\mathrm{I}^{\mathrm{B}}$ values are given the highest rank in the risk-based prioritization for inspection planning. Components having high $I^{\mathrm{w}}$ values are then added into this list of highly ranked components. The results of system prioritization for Surry-1 from an earlier PNL study (Vo et al. 1990) are shown in Table 2.1.

For those systems selected for further analyses, a detailed component-level prioritization was performed. The FMEA technique was selected for this analysis.
The FMEA results were used to calculate the importance index (or relative importance) for each component within the selected systems. The importance index was based on the expected consequence of failure of the component, as measured by the probability of core damage resulting from component failure. In mathematical terms, the probability of core damage, $\mathbf{P}_{\mathbf{c m}}$, resulting from a given component failure (i.e., rupture), is defined as

$$
P_{\mathrm{cm}}=P_{\mathrm{f}} * \sum_{i} P_{\mathrm{cm}}\left|s_{\mathrm{i}} * P_{\mathrm{s}_{\mathrm{i}}}\right| P_{\mathrm{f}} * R_{\mathrm{i}}
$$

$$
\begin{aligned}
& \text { where } P_{\mathrm{cm}}=\text { probability of core damage resulting } \\
& \mathbf{P}_{\mathrm{f}} \quad=\text { failure (rupture) probability of the } \\
& \mathrm{P}_{\mathrm{cm}} \mid \mathrm{s}_{\mathrm{i}}=\text { conditional probability of core dam- } \\
& P_{s_{i}} \mid P_{f}=\text { conditional probability of system } i \\
& \mathbf{R}_{\mathrm{i}} \quad=\text { probability that the operator fails to }
\end{aligned}
$$

Equation (2.2) is totaled for all system failures that either result directly from the given component failure or result indirectly from component damage to other components or the systems in the zone of interest (e.g., pipe whip or jet impingement effects, damaging vital electrical buses, etc.). The Standard Review Plan developed by the NRC (1981) and information obtained from plant system walkdowns are used to assess the indirect effects.

As shown by Equation (2.2), estimates of component failure probabilities are required in order to perform component prioritization. These estimates are summarized in the following subsection.

\subsection{Estimates of Component Rupture Probabilities}

For each system selected (Table 2.1), the per-component failure probability was estimated. Because historical failure data on low-probability events (e.g., pipe rupture) are lacking, an expert judgment elicitation was used to estimate component failure probabilities. This section summarizes the procedures and the results of 
Table 2.1. System Level Importance Ranking for Surry-1 ${ }^{(a)}$

$\frac{\text { System }}{\text { High-Pressure Injection }}$
Low-Pressure Injection
Reactor Pressure Vessel
Auxiliary Feedwater
Service Water ${ }^{(b)}$
Steam Generator
Reactor Coolant
Power Conversion

(a) Obtained from Vo et al. (1990). Values in parentheses represent the system Birnbaum Importance Mcasure results or their associated rankings.

(b) Including the component cooling water system.

$\frac{I^{\mathrm{W}}\left(\mathrm{I}^{\mathrm{B}}\right)}{1.3 \mathrm{E}-05(1.4 \mathrm{E}-02)}$
$6.1 \mathrm{E}-06(1.6 \mathrm{E}-02)$
$5.0 \mathrm{E}-06(1.0)$
$3.9 \mathrm{E}-07(8.2 \mathrm{E}-03)$
$1.0 \mathrm{E}-07(2.2 \mathrm{E}-03)$
$5.1 \mathrm{E}-08(5.1 \mathrm{E}-06)$
$2.9 \mathrm{E}-08(6.1 \mathrm{E}-04)$
$1.9 \mathrm{E}-09(5.1 \mathrm{E}-06)$
parentheses represent the system Birnbaum
ted rankings.

\section{Ranking}

1 (3)

3 (1)

4 (4)

$5(5)$

$8(7)$
PNL's expert judgment clicitation. More detailed discussions are given in Vo et al. (1991).

The expert judgment elicitation used a systematic procedure, which closely followed the approaches reported in the NRC Severe Accident Risks Document (NRC 1989; Wheeler et al. 1989; Meyer et al. 1989). The specific objective of the PNL elicitation was to develop numerical estimates for probabilities of catastrophic or disruptive failures in the sclected components at Surry1. Figure 2.1 shows information that was used to obtain the desired estimates from the experts.

Prior to the expert elicitation workshop, PNL sent reference materials to the experts, including data sources, reports, probabilistic models, and recent PRA results. Panel members were asked to study these materials and to make initial estimates of failure probabilities.

At the meeting, a formal presentation was provided for each system addressed. Presentations covered technical descriptions, historical component failure mechanisms, elicitation statements, suggested approaches, questionnaire forms, and any materials that supported the issue descriptions. The presentations were followed by discussions. The experts provided their knowledge regarding plant design and operation, failure history, material degradation mechanisms, and methods for recomposition and aggregation of the data.
Each expert then completed questionnaire forms that addressed location-specific rupture probabilities for the systems of interest. These responses included best estimates of probabilities and uncertainties, and the rationale for these estimates. Following the meeting, the information provided by the expert panel was recomposed and aggregated. PNL prepared a preliminary report of the elicitation, which was then submitted to each panel member for review. This report included the initial recomposition, additional plant-specific data, and other relevant information. The experts were requested to review and revise their estimates of rupture probabilities. The revised information was again recomposed and aggregated to provide single compositc judgments for each issue.

Figure 2.2 shows a sample of estimated failure probabilities obtained from the expert judgment approach. Similar types of plots were produced for components in other selected systems at Surry-1. For readability, the probabilities are presented with a $\log _{10}$ scale, with the probabilities expressed as failures per component per year. The ranges of best estimates from the experts were summarized in a series of plots (boxes and whiskers) as shown in Figure 2.2. An individual plot displays five features of the distribution of estimated probabilities. The "whiskers" display the extreme upper and lower bound values of the distribution, while the box itself locates the $25 \%$ and $75 \%$ quartiles of the distribution. Finally, the circle within the box is the median of the distribution. 


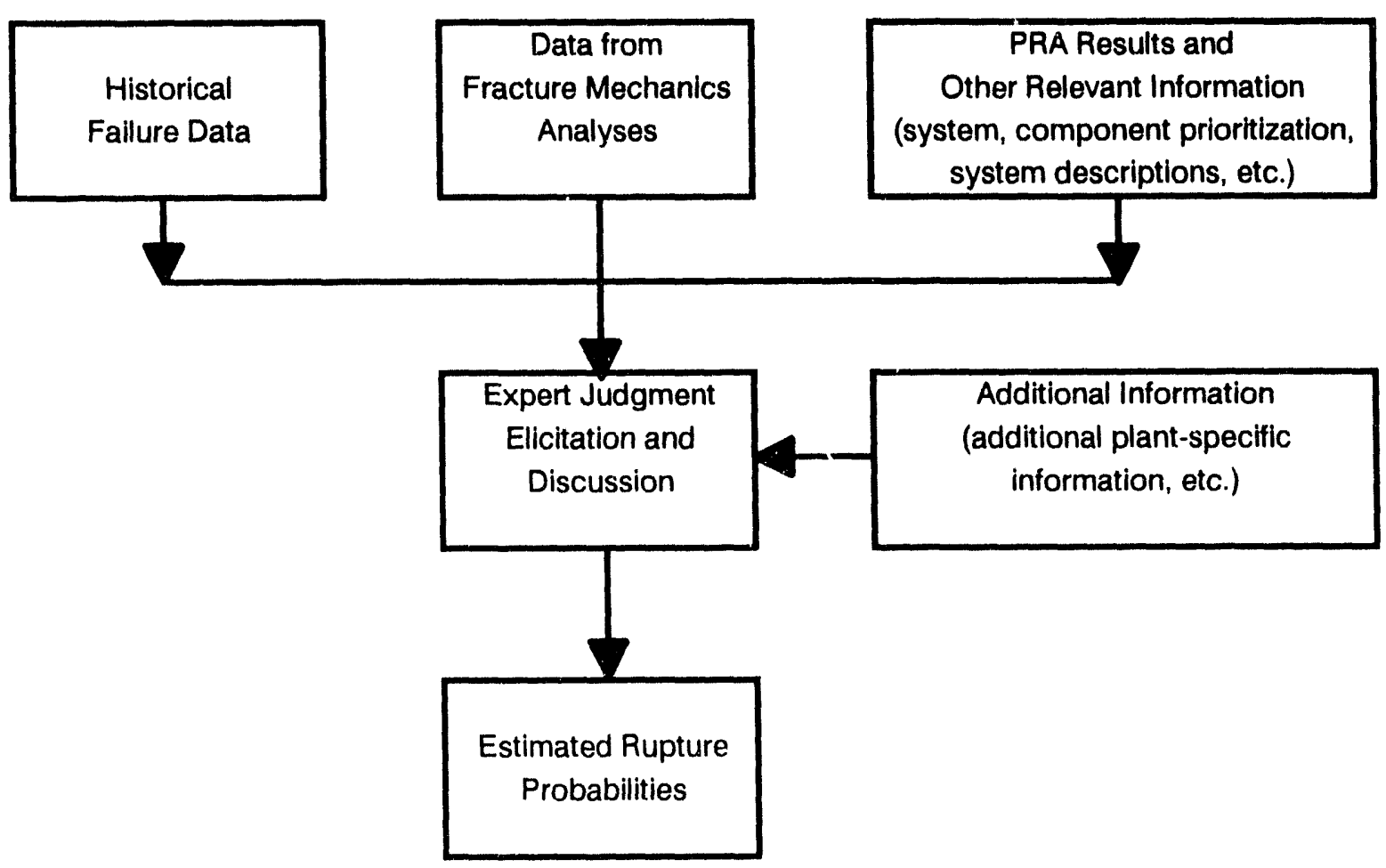

Figure 2.1. Information Provided to Expert Panel

\subsection{Target Risk and Rupture Proba- bility}

The purpose of inspections is to keep risk levels within acceptable values (e.g., by detecting and repairing degraded components before they lead to rupture). It is a difficult task to select acceptable (or target) values for the risk associated with pressure boundary component and structural failures. However, once the target risk values are determined, the corresponding target rupture probabilities for individual components can be quantified using the methods described in the preceding subsections. This subsection proposes an approach for defining the target risk and the target rupture probabilities.

A philosophical approach for selecting target values of risk and rupture probability for individual components has been recommended by ASME Research Task Force on Risk-Based Inspection (ASME 1991). This approach assumes that the inspection should ensure that the risk of core damage resulting from pressure boundary component structural failures is maintained to be less than a small fraction of the total core damage risk estimated by the PRA. The risk due to pressure boundary structural failures is referred to as the "target risk," and 5\% of the total PRA-estimated risk resulting from internal events has been recommended as an appropriate numerical value.

It is further recommended that this overall target risk be apportioned among the risk-important components by considering the risk associated with rupture of each component. Using the conditional probability of core damage given component failure, the target failure probability can be calculated for each component from its apportioned share of the overall target risk value. From this, inspection strategies can be determined to maintain component rupture probabilities below target values, and optimum strategies can then be selected. An example of the target risk and component rupture probability calculations is provided in the next section to clarify the discussion. 
2.0 Overall Methodology

Wold 1

Weld 2

Weld 3

Weld 4

Weld 5

Weld 6

Weld 7

Weld 8

Weld 9

Weld 10

Weld 11

Weld 12

Weld 13

Weld 14

Weld i5

Nozzle Forgings - Inlet

Nozzle Forgings - Outlet

Beltline Plate

Vessel Shell - Outside

Upper Head

Lower Head

Vessel Flange

Enclosure Head Flange

Vessel Studs

CRDMs

Instrument Line

Penetrations

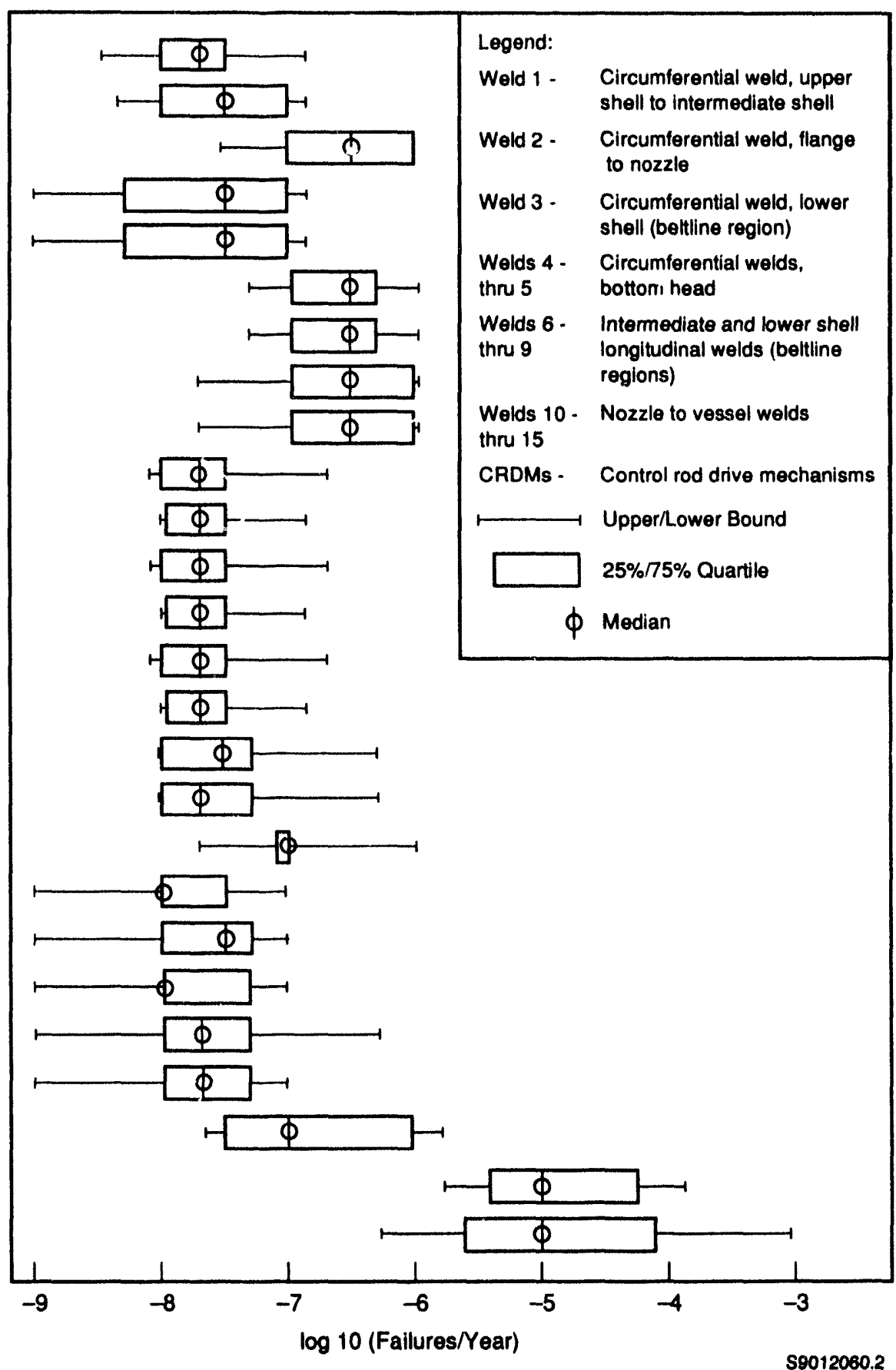

$\$ 9012060.2$

Figure 2.2. Estimates of Failure Probabilities for Surry-1 Reactor Pressure Vessel Components from Expert Judgement Elicitation 


\subsection{Analyses of Surry-1 Plant Systems}

This section presents analyses of the four selected Surry-1 systems. Identification and prioritization of components for the Surry-1 plant systems are provided following a brief discussion of plant familiarization, system descriptions, and analysis assumptions. The section concludes with sensitivity analyses.

\subsection{Plant Familiarization}

Participation of VEPCO was an essential part of the pilot study. Before initiating the pilot study, a visit to VEPCO headquarters was conducted. The purpose of this first visit was to get acquainted with VEPCO personnel and to request needed data.

Prior to the initial plant visit, the project team analysts reviewed the fault trees reported in the Surry-1 PRA, the system descriptions, and the sections of the final safety analysis report (FSAR) applicable to the systems of interest. The preliminary FMEA models were constructed and preliminary success criteria and dependency matrices were developed to identify specific areas where information was needed to develop an accurate model. Based on these initial activities, a letter of request was prepared and sent to the plant to identify the plant-specific information and data that was required. The following subsections provide a description of the plant visit and the information obtained during the visit.

\subsubsection{Initial Plant Visit}

A one-week plant visit was arranged to meet with plant personnel. During this visit, project team analysts performed the system walkdowns and obtained relevant plant information. The visiting PNL team included plant system specialists and PRA specialists. Because the plant was in operation during the initial visit, system walkdowns for some locations were not possible (e.g., inside the containment building and other high-radiation areas). Therefore, the Video Information Management System (VIMS) developed by VEPCO was also used. VIMS is a computerized system, that displays photographs of plant systems and components that have been stored in digital form on a laser disc. Following simple instructions, the plant photographs could be retrieved and viewed at any location within the plant.

For each of the systems selected for the study, a system walkdown was conducted where possible. The informa- tion obtained from the walkdowns was later used to assess the indirect effects on the systems. The walkdowns for each system included the plant engineer and one or two project team analysts. For each component (e.g., pipe segment), all the necessary information related to that component was obtained. This information was entered into the preliminary FMEA models. For example, for a given pipe segment within a selected system, the component identification, including the pipe size, was identified. Numbers of welds, elbows, supports, connections, penetrations, etc., within the pipe segment in question were identified and recorded. Given a component failure, the potential targets that might be impacted by the failed components (e.g., vital electrical buses, system components nearby, etc.) were also recorded. Additionally, a video camera was used to record the conversations with the responsible engineer and views of significant locations of concern to system design and operation as identified during the initial visit.

In addition to the plant system walkdowns, discussions with plant operational and technical staff were also conducted. The areas of discussion included plant and system modeling questions, collections of system design and operational information, discussions of transient sequence progressions, and the operators' responses to these events. During the plant visit the team had discussions with the Surry-1 supervisor of system safety, the operator training coordinator, and the supervisor of the ISI. Project analysts talked with reactor operators, the shift technical advisor, and members of the maintenance and engineering staff.

Discussions centered on gaining a clear understanding of the following items:

- the normal and emergency configurations and operations of the various systems of interest

- $\quad$ system dependencies

- operational problem areas identified by plant personnel that may impact the analysis

- automatic and manual actions taken in response to various emergency conditions

- availability of plant specific operational data. 
The emergency procedures which addressed actions identified by the project analysts as important actions were explained to operations personnel.

\subsubsection{Information Obtained}

A complete set of the current Surry piping and instrumentation drawings (P\&ID), isometric drawings, composite drawings, and stress analysis reports were provided by the Surry-1 staff. Also, the Surry-1 staff provided copies of the Surry Emergency Procedures, Abnormal Procedures, Emergency Contingency Action Proceaures, Functional Restoration Procedures, and several sections from the current revisions of the Surry-1 FSAR. The plant information was incorporated into PNL's preliminary FMEA models. For instance, the isometric and composite drawings were used to obtain additional information regarding component orientation and number of subcomponents. The Emergency Procedures were used to assess the recovery actions by the operators given a rupture of component.

\subsubsection{Subsequent Plant Visits}

During the course of the study, two additional plant visits were conducted. The first visit was to obtain additional plant-specific failure mechanisms for components within the system analyzed. This information was provided to an expert workshop on estimating component rupture probabilities. The other plant visit was conducted during the plant shutdown for refueling. This visit was to obtain additional information and to verify the information that was obtained from an initial visit (e.g., areas inside the containment building). PNL is currently performing the pilot study for the Surry-1 balance of the plant system and additional plant visits are anticipated.

\subsubsection{Utility Interface}

An ongoing interface was maintained with the utility throughout the duration of the analysis. The project team leader was in frequent contact with Surry-1 plant personnel to ask questions and verify information. Surry-1 personnel also reviewed the results of the study when they became available.

\subsection{Plant System Description}

Surry-1 is part of a two-unit plant located on the James River near Williamsburg, Virginia. Surry-1 is a Westinghouse-designed, three-loop, pressurized-water reactor (PWR) rated at $788 \mathrm{MWe}$ capacity with a sub-atmospheric containment. The balance of the plant and containment building were designed and constructed by Stone and Webster Engineering Corporation. Surry-1 is operated by VEPCO. Commercial operation started in 1972.

The Surry-1 systems selected for study were the primary pressure boundary system, the front-line safety systems, and certain important support systems identified in Table 2.1. These were the reactor pressure vessel (RPV), reactor coolant (RCS), low-pressure injection (LPI), and the auxiliary feedwater (AFW) systems. The following paragraphs summarize the descriptions for these systems. Detailed descriptions can be found in the Surry-1 FSAR.

\subsubsection{Reactor Pressure Vessel}

The RPV is a principal component of the RCS. The Surry-1 RPV is shown in Figure 3.1. It consists of a cylindrical shell with a hemispherical bottom head, and a flanged and gasketed removable upper head. The vessel contains the core, core support structures, control rods, thermal shield, and other parts directly associated with the core. Outlet and inlet nozzles are located between the upper head and the core.

The Surry- 1 vessel was designed and manufactured by the Babcock and Wilcox Company to the requirements of Section III of the ASME Boiler and Pressure Vessel Code (BPVC). Design features and materials selection are typical for PWR reactor vessels at U.S. nuclear plants. The vessel is designed of low-alloy steel with forgings of Type A508, Class 2 and plate materials of Type A533, Grade B, Class 1. All surfaces in contact with coolant are clad with, or made from, 300-series stainless steel or Inconele. In general, all attachments and pressure-containing parts have full-penetration welds. Partial welds are used to attach the relatively small diameter control rod drives and the instrumentation tubes to the vessel heads. 


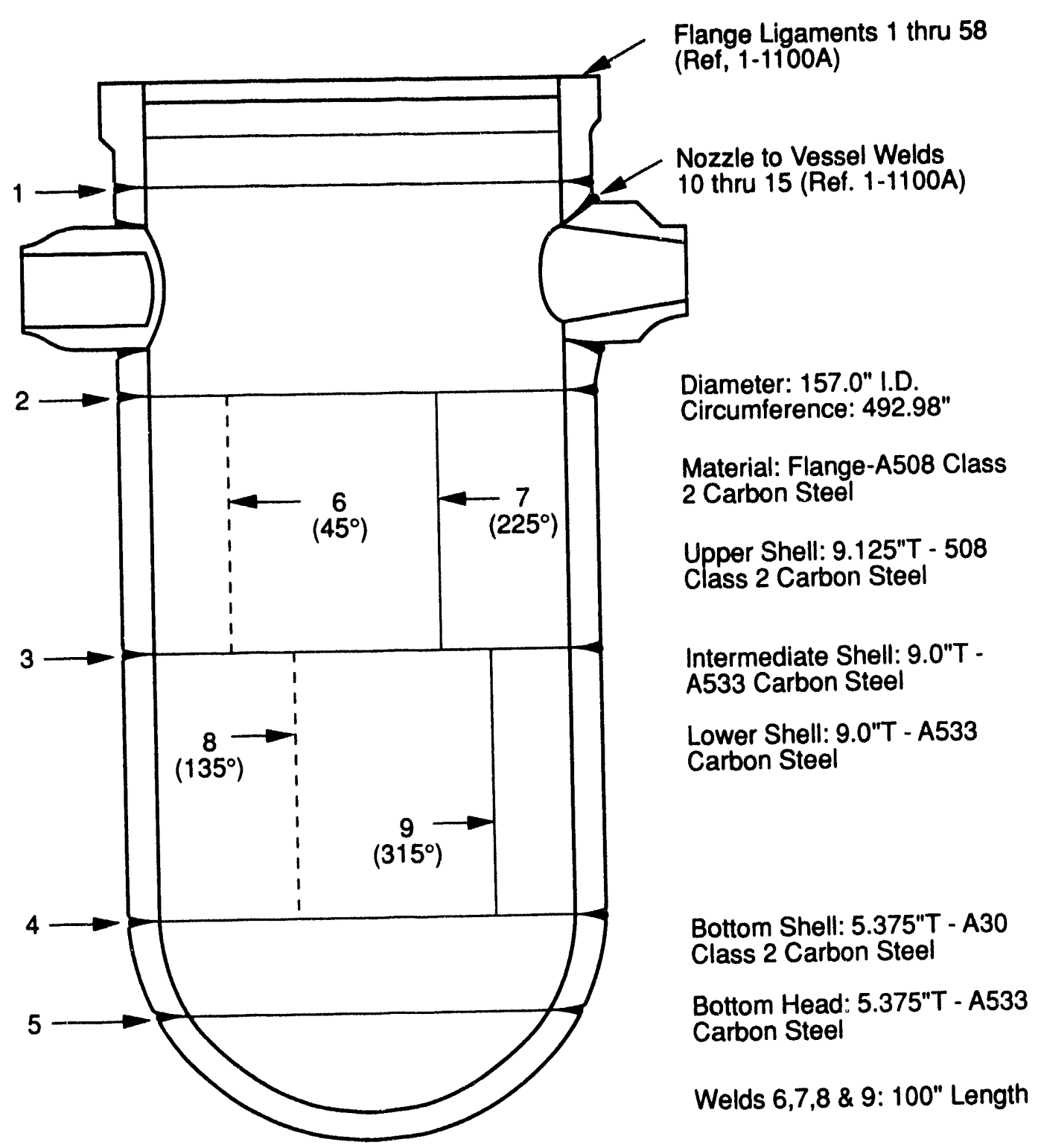

S9201018.1

Figure 3.1. Surry-1 Reactor Pressure Vessel Simplified Schematic

\subsubsection{Reactor Coolant System}

The function of the RCS is to remove heat and transfer it to the secondary system. It also provides a barrier against the release of reactor coolant or radioactive materials to the containment environment. The RCS for Surry-1 is diagramed in Figure 3.2. It consists of three identical heat transfer loops (connecting parallel to the RPV), each of which includes a steam generator, reactor coolant pump, and connecting piping and instrumentation for flow and temperature measurements.

The pipes through which the heated water flows from the RPV to the steam generator are called the "hot legs" and the pipes through which the cooled water 


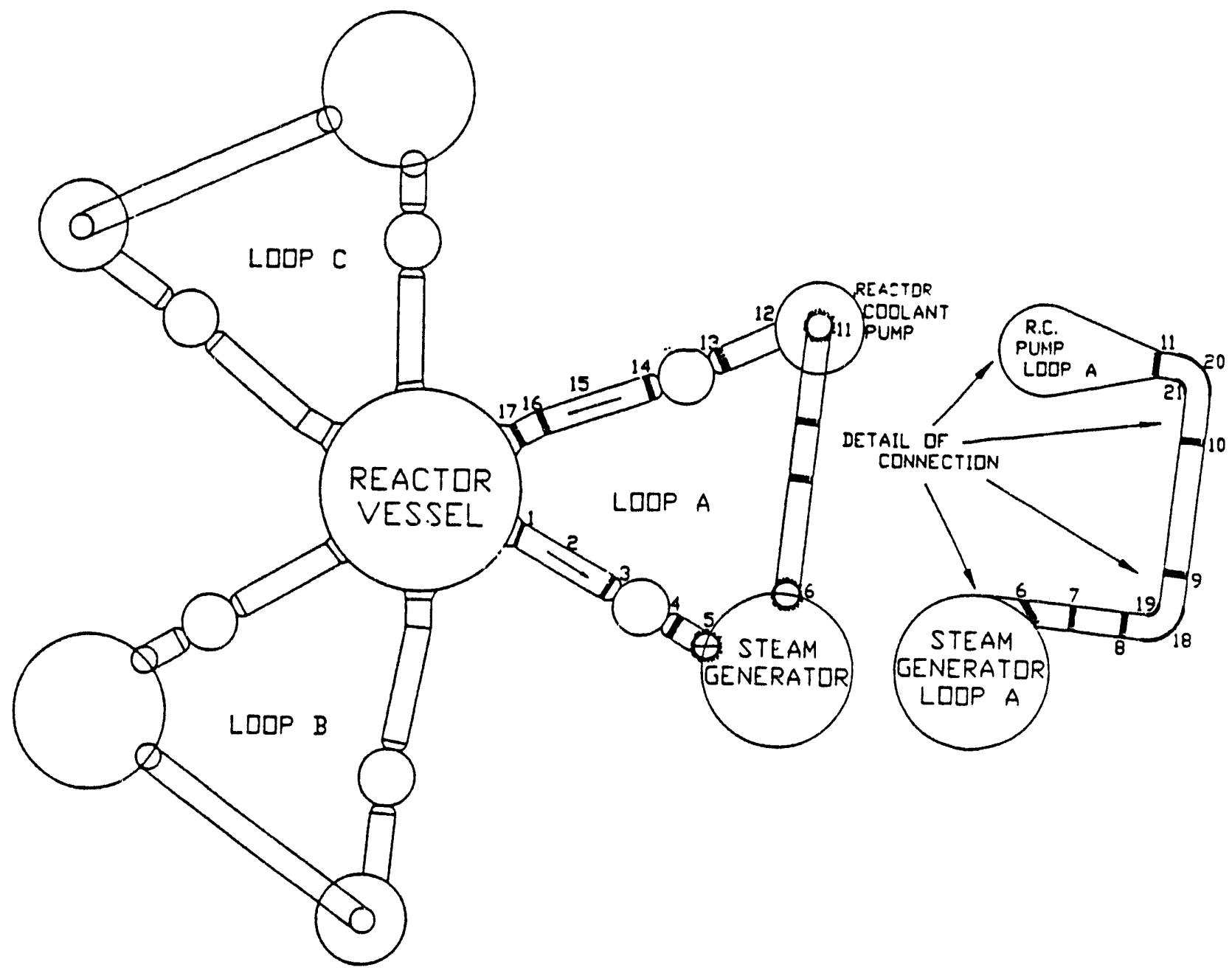

Figure 3.2. Surry-1 Reactor Coolant System Simplified Schematic

flows irom the steam generator and back into the RPV are called the "cold legs." The working fluid is boiled on the secondary sides of the steam generator and transported through a conventional turbine-condenser system.

The RCS also includes a pressurizer that maintains the reactor coolant at a constant pressure. The pressurizer system consists of power-operated relief valves with associated block valves, ASME code safety valves, pressurizer sprays, and electrical heaters. There is continuous control of the water and steam inventory within the pressurizer vessel. The pressurizer is connected to a coolant loop and is maintained at the saturation temperature that corresponds to the system pressure.

To regulate the reactor coolant chemistry within design limits and control the pressure level, a constant letdown flow from one loop upstream of the reactor coolant pump is maintained. This flow is, in turn, controlled by the pressurizer level. Constant coolant makeup is added by charging pumps in the chemical and volume control systems. The inservice integrity of the RCS is addressed through periodic inspections performed in accordance with the requirements of ASME, Siction XI. 


\subsubsection{Low-Pressure Injection System}

The LPI consists of several independent subsystems characterized by equipment and flow path redundancy inside the missile protection boundaries. The two phases of low-pressure system operation including active low-pressure injection and recirculation mode and the passive accumulator injection are summarized below.

The Surry-1 low-pressure injection/recirculation system (LPI/LPR) provides emergency coolant injection and recirculation following a loss-of-coolant accident (LOCA) when tie RCS depressurizes below the lowpressure setpoint (about $300 \mathrm{psig}$ ). In addition to the direct recirculation of coolant during the recirculation phase once the RCS is depressurized, the LPR discharge provides the suction source for the high-pressure recirculation system following drainage of the refueling water storage tank (RWST).

The LPI/LPR at Surry-1 is diagrammed in Figure 3.3. The system consists of two $100 \%$ capacity pump trains. In the injection mode, the pump trains share a common suction header from the RWST. Each pump draws suction from the header through normally open motoroperated valves (MOVs), check valves, and locked-open manual valves. Each pump discharges through a check valve and normally open MOV in series to a common irjection header. The injection header contains a locked-open MOV and branches to separate lines, one to each cold leg. Each of the lines to the cold legs contains two check valves in series to provide isolation from the high-pressure RCS.

In the recirculation mode, the pump trains draw suction from the containment sump through a parallel arrangement of suction lines to a common header. Flc $N$ from the suction header is drawn through a normally closed MOV and check valve in series. Discharge of the pump is directed to either the cold legs through the same lines used for injection or to a parallel set of headers that feed the charging pumps, depending on the RCS pressure.

In the hot-leg injection mode, system operation is identical to normal recirculation with the exception that the normally open cold-leg injection valves must be manually closed remotely, and one or more normally closed hot-leg recirculation valves must be marually opened.
The accumulators, which are passive components, serve as another injection mode for the LPI system. They provide an initial influx of borated water to reflood the reactor core following a large or medium LOCA. The accumulator system, diagrammed in Figure 3.4, consists of three tanks filled with borated water and pressurized with nitrogen. Each of the accumulators is connected to one of the RCS cold legs by a line containing a normally open MOV and check valve in series. The check valves serve as isolation valves during normal operation and open to empty the contents of the accumulators when the RCS pressure falls below 650 psig.

The accumulators depend on the nitrogen system to maintain the pressure hedd. The nitrogen is supplied by dedicated local nitrogen bottles, and the accumulators are fully instrumented to indicate abnormal pressure conditions. The accumulators are initially filled with borated water storage from the RWST, and the valves are closed. Instrumentation verifies that the level remains above a minimum value.

The associated components, piping, structures, and power supplies of the LPI system (including the accumulators) are designed to conform with Class 1 seismic criteria. All motors, instruments, transmitters, and their associated cables located inside the containment are designed to function during and under the postulated temperature, pressure, and humidity conditions.

All LPI piping in contact with borated water is austenitic stainless steel. The piping is designed to meet the minimum requirements set forth in B31.1 Code for Pressure Piping, B36.10 and B16.19, ASTM Standards, Supplementary Standards, and Additional Quality Control Measures. The piping is supported to accommodate expansion due to temperature changes and hydraulic forces during an accident. All components of the LPI/LPR and accumulators are tested periodically to demonstrate system readiness. All pressure piping butt welds containing radioactive fluid, at greater than $600^{\circ} \mathrm{F}$ and $600 \mathrm{psig}$, were radiographed. The remaining piping butt welds were randomly radiographed. Pressurecontaining components are inspected for leaks from pump seals, valve packing, flanged joints, and safety valves during system testing. Frequency of testing and maintenance of the system components are specified in the ASME, Section XI. 


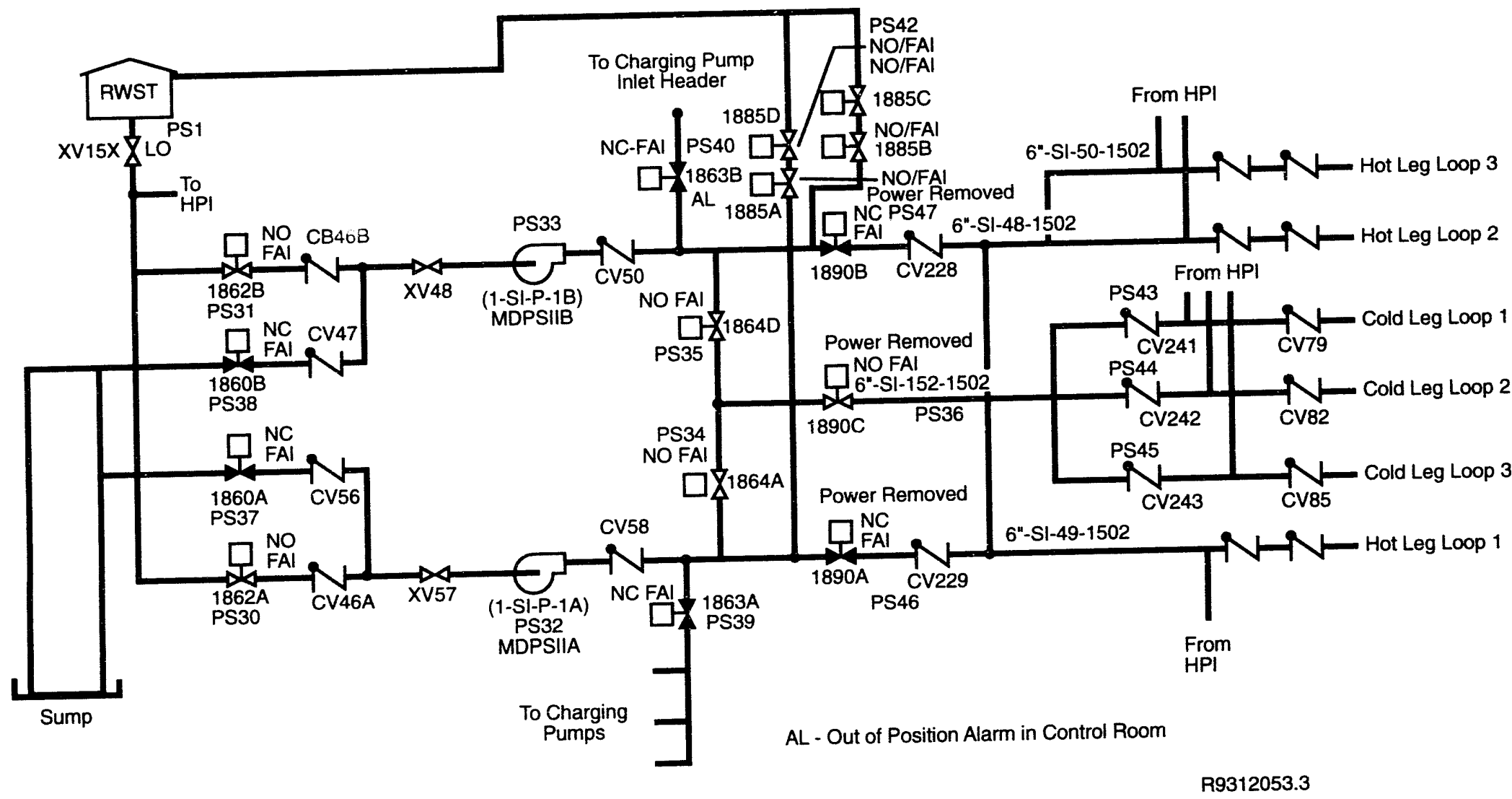

Figure 3.3. Surry-1 Low-Pressure Injection/Recirculation System Simplified Schematic 


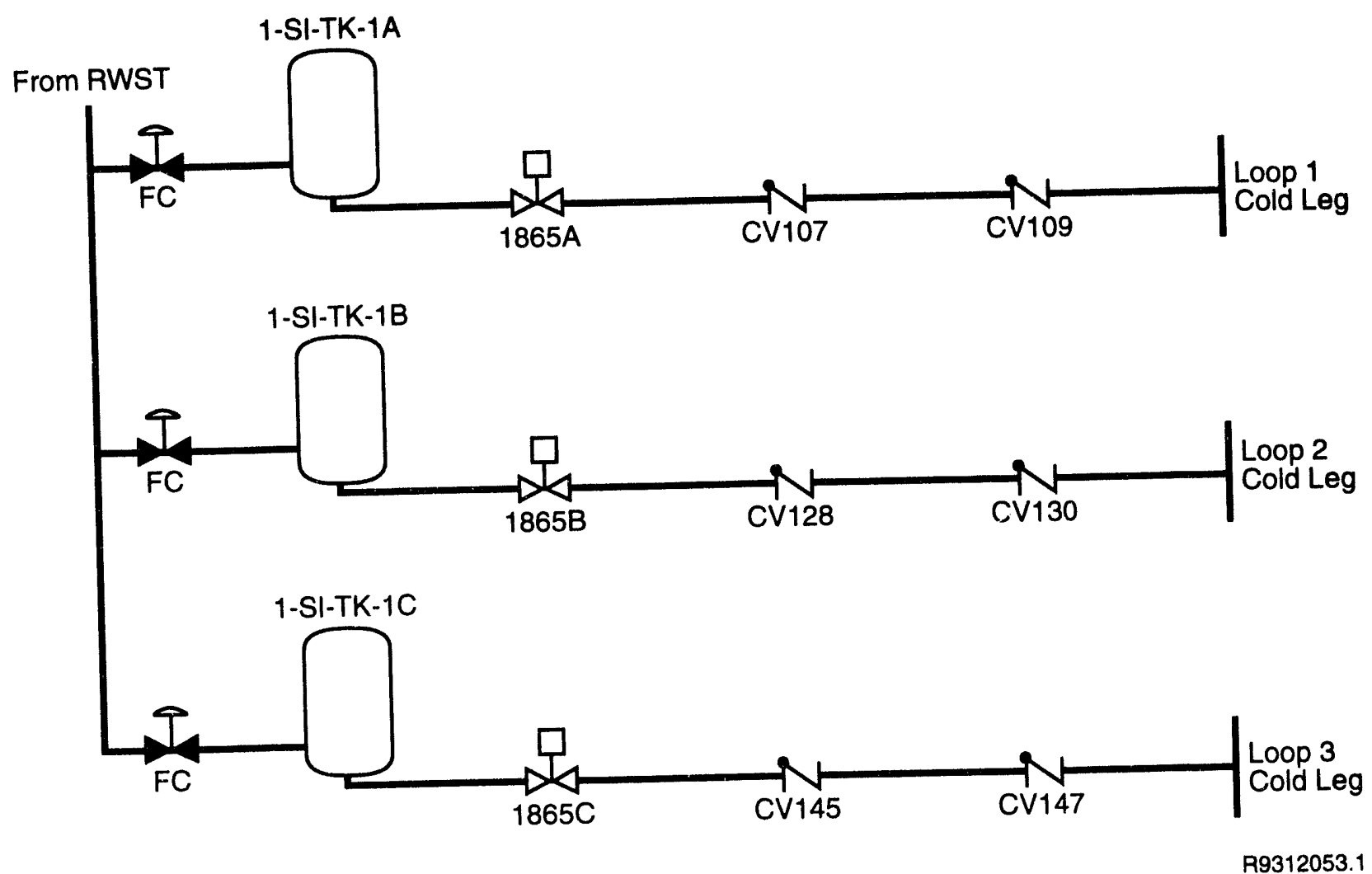

Figure 3.4. Surry-1 Accumulator System Simplified Schematic

\subsubsection{Auxiliary Feedwater System}

The AFW system provides feedwater to the steam generators for heat removal from the primary system after a reactor trip. The AFW system may also be used following a reactor shutdown, in conjunction with the condenser dump valves or atmospheric relief valves, to cool the RCS to about $300^{\circ} \mathrm{F}$ and $300 \mathrm{psig}$, at which time the residual heat removal system is brought into operation. The AFW system also provides emergency water following a secondary-side line rupture. Removal of heat in this manner prevents the reactor coolant pressure from increasing and causing release of reactor coolant through the pressurizer relief and/or safety valves.

The AFW system is diagramed in Figure 3.5. The AFW is a multiple-train system; it consists of electric motor-driven pumps and steam turbine-driven pumps. Each pump draws suction through an independent line from the condensate storage tank. Each AFW pump discharges to parallel headers; each of these headers can provide AFW flow to any or all of the steam generators. Flow from each header to any one steam generator is through a normally open MOV and locked-open valve in series, paralleled with a line from the other header. These lines feed one line containing a check valve that joins the main feedwater line to a steam generator.

The motor-driven pumps automatically start on receipt of a safety actuation system signal, loss of main feedwater, low steam generator level in any steam generator, or loss of off-site power. The turbine-driven pumps automatically start on indication of a low steam generator level in any steam generator or undervoltage of any of the main RCS pumps.

Most of the AFW equipment is located in the auxiliary building. This building is designed to withstand the effects of earthquakes, tornadoes, floods, and other natural phenomenon. Provisions are incorporated in 

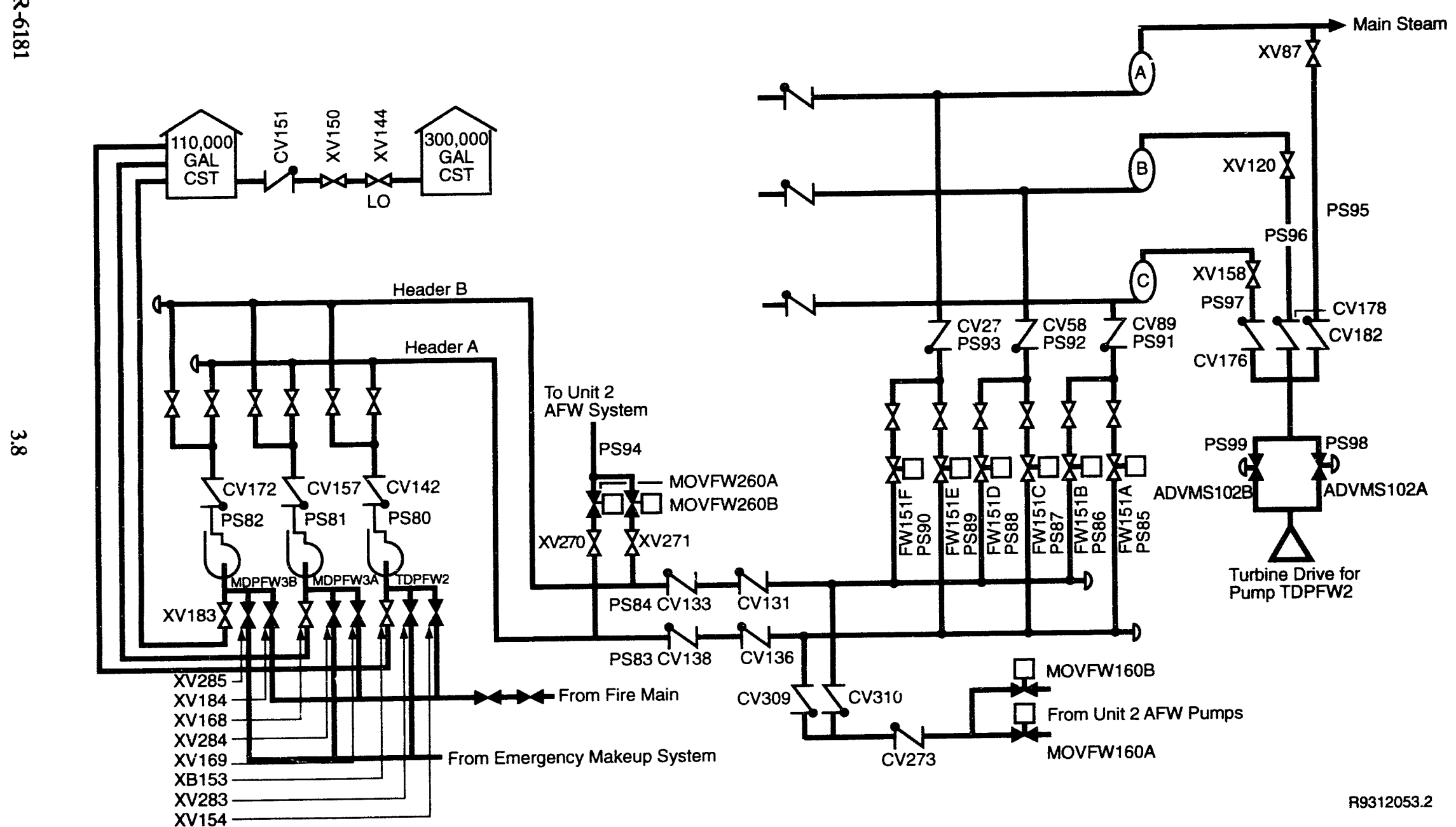
the AFW design to allow periodic operation to demonstrate performance and structural leak-tight integrity. Leak detection is provided by visual examination and sensors in the floor drain system. The capability to isolate components or piping is provided, if required, so that the AFW system's safety function will not be compromised. Provisions are made to allow for ISI of components at the appropriate times specified in the ASME, Section XI.

\subsection{Analyses Assumptions}

General assumptions used for the analyses are the following:

- Core damage frequency was used as the bottom-line risk measure to prioritize plant system components.

- For the four selected systems, the discrete components (piping segments, welds, etc.) are identified for purposes of the risk-based evaluation. For the RPV, the major components of interest were the vessel shell, heads, flanges, closure studs, penetrations, nozzles and safe ends, and attachment welds. For other systems, the components of interest were pipe segments. These included the straight lengths of pipe, pipe elbows, couplings, fittings, flanged joints, and welds. Additionally, tanks and heat exchangers, including the pressurizer, are also included as components in the analyses.

- The system Birnbaum Importance results were used to provide the conditional probabilities of core damage given the system failures.

- Identical components in identical trains within the same system were assumed to have the same failure consequences.

- In these analyses, failures in piping of less than 1 -in. in diameter generally are not considered, primarily because of the enormous amount of instrumentation piping of this size. Active functions of components such as pumps and valves, which make up part of the system pressure boundary, are not considered. However, failures of these components as pressure boundaries are addressed. Steam generator tube failures have been considered in other studies and are not included in this study.

- The Standard Review Plan 3.6.2, developed by the NRC (1981), was used in determining the indirect effects (e.g., pipe whip, jet forces, etc.) of component failures, as such failures relate to other components in the zone of interest (e.g., vital electrical buses). Additionally, when a larger diameter pipe impacts a smaller diameter pipe of the same pipe schedule, a smaller diameter pipe is assumed to fail.

- Potential flooding due to pipe ruptures that could damage safety-related systems and equipment are not included in these analyses. Floodings will be addressed at the later date.

\subsection{Component Prioritization}

The quantitative FMEA technique, as described in Section 2.0, was used to prioritize components on the basis of core damage risk. In summary, the following sources of information were used to prioritize components for inspection: 1) the component failure probabilities estimated from expert judgment elicitation (Vo et al. 1990), 2) the results from Surry-1 system prioritization (Vo et al. 1989), and 3) system fault trees reported in the Surry-1 PRA (Bertucio and Julius 1990). The Integrated Reliability and Risk Analysis System (IRRAS) computer program developed by Idaho National Engineering Laboratory (Russel et al. 1987) was used to reanalyze the developed fault trees (e.g., calculate the conditional probability of system failure given a component failure).

The FMEAs were initially formulated using plant system drawings and other relevant plant-specific information. As stated in the assumptions, Standard Review Plan information developed by the NRC was used in determining the potential effects of system component failures on other components in the zone of interest. To ensure that plant models were as realistic as possible and reflected plant operational practices, visits to 
the Surry-1 plant were conducted for plant system walkdowns, and discussions were held with plant operational and technical staff. For locations where the walkdowns were not possible, (e.g., high-radiation areas) the VIMS developed by VEPCO was used to identify the potentially impacted systems and equipment (given a failure of a component in the zone of interest).

The FMEA worksheets were devised so that the necessary information could be systematically tabulated. In the following paragraphs, the example of the RPV (using Equation 2.2) is discussed. Copies of FMEA worksheets are provided in Appendix A of this report.

The first step of the analysis was to identify the component locations and/or the number of subcomponents within a specified pipe segment or region. For example, the beltline region of the Surry-1 RPV consists of five welds (four longitudinal welds and one circumferential weld). The per-weld failure probability, $\mathbf{P}_{f}$, was estimated as 3.2E-07 (see Figure 2.2). The failure probability of the beltline region (five welds) was estjmated as $5^{*}(3.2 \mathrm{E}-07 /$ weld $)=1.6 \mathrm{E}-06$.

As discussed in a previous section, the consequences of component failures were to be placed into two categories, those that resulted in direct effects on the system in question and those that resulted in effects on other systems or components in the zone of interest (e.g., component failures due to pipe whip or jet impingement effects). In either case, the total contribution to core damage, given a failure of the component under consideration, were assessed (e.g., the product of the conditional probability of core damage given system failures and the probability of system failures given component failures, $\left.\mathrm{P}_{\mathrm{cm}}\left|\mathrm{s}{ }^{*} \mathrm{P}_{\mathrm{s}}\right| \mathrm{P}\right)$.

Information from prior system level prioritizations, system walkdowns, discussions with VEPCO staff, the Standard Review Plan, and the fault trees reported in the Surry-1 PRA were used to quantify the failure effects. The system fault tree was reanalyzed to estimate the probability of system failure given a component failure. The IRRAS computer program was used to calculate probabilities of system failure given a component failure. Generally, the Birnbaum Importance Measure for the system was used to provide the conditional probability of core damage given a system failure. For the RPV, the primary effect of a weld failure was the loss of the vessel $\left(P_{s} \mid P=1.0\right)$. In this case, the probability of core damage, given the vessel failure, $\mathrm{P}_{\mathrm{cm}} \mid \mathrm{s}$, was assumed to be $\mathbf{1 . 0}$.

Depending on failure location and/or accident scenario, the recovery action, $\mathbf{R}_{\mathrm{i}}$, was assigned an estimated probability based on discussions with the plant technical staff and on information obtained from the PRA. For the reactor pressure, no recovery action was possible. It is important to note that in this study the probability of recovery by the operator staff was incorporated in the system prioritization scheme. To prevent double counting, the recovery actions were assessed qualitatively. For each postulated failure of a component within the selected systems, the core damage probability was calculated. A computer program was developed for the calculations.

The product of the component failure probability and the corresponding core damage probability given a failure of the component, was calculated. This value describes the expected risk-based implication of the component under consideration. In the vessel example, failures of welds at the vessel beltline region were assumed to result in loss of the vessel, and the core damage probability per plant year was estimated to be $(1.6 \mathrm{E}-06) * 1=1.6 \mathrm{E}-06$.

On the FMEA worksheets the relative importance of each component was calculated as illustrated above (e.g., 1.6E-06* 1). An importance index was used to rank each component in a given system by normalizing its core damage probabilities to that of a component with the highest core damage probability. The highest value of the index identifies the component that is the most important for the system being analyzed. A final combined ranking of components for all four systems together was developed based on the numerical values for core damage frequency.

\subsection{Results of Analyses}

Within the four systems analyzed, there are approximately 250 major components (or pipe segments). By assuming that identical components in identical trains within the same system have the same failure probabilities and consequences, these components are reduced to approximately 125 components. For ranking purpose, components within the same train can be further grouped, based on major discontinuities (e.g., between 
pumps and major valves). This resulted in 37 major component groups within the systems analyzed.

Table 3.1 shows the results of the risk-based ranking of major components within the four selected systems at Surry-1, based on the contributions of component failures to core damage frequency. Included in the table are the upper-and lower-bound values estimated for each component to indicate the effects of uncertainties in the estimates of component rupture probabilities. The rankings (as shown in the table) are based on the median values estimated from the Surry-1 PRA and PNL evaluations of other factors such as rupture probabilities, as discussed in the preceding section. Figure 3.5 presents this information graphically for the components in the four systems.

As shown in Table 3.1, the contributions of individual component failures to core damage frequency (based on the median values) range widely from about $1.6 \mathrm{E}-14$ to $1.58 \mathrm{E}-06$ per plant year. The cumulative risk contribution from all components as shown in Figure 3.6 is about 2.1E-06 per plant year. Figure 3.7 shows this cumulative risk contribution. It is interesting to note that the risk contribution is dominated by approximately the first 18 highest-ranked components. The system level rankings obtained by summing component contributions are the following: 1) RPV, 2) LPI, 3) AFW, and 4) RCS. These system level rankings agree with those obtained in an earlier PNL study (Vo et al. 1989).

For the purpose of comparison, the components are also ranked on the basis of the calculated values of conditional probability of core damage given a component failure. Table 3.2 shows this ranking based on the median values estimated. Figure 3.8 presents this same information graphically. The conditional contributions of component failures to core damage range from 1.0 to about 1.0E-07. As expected, the highest contributions are from RPV components, since rupture of the RPV beltline region leads directly to core damage. Conditional contributions to core damage from the LPI, the AFW, and the RCS components are lower due to the ability of redundant safety systems to mitigate accidents and, hence, prevent core damage. Table 3.3 shows the risk importance parameters for 37 major components identified in Table 3.1. The component rupture frequencies (as shown in Table 3.3) were the average of component group.

\subsection{Sensitivity and Uncertainty Analy- ses}

There are various sources of uncertainty in the numerical results of this study. This section describes specific sources of uncertainty and provides the results of uncertainty/sensitivity analyses.

\subsubsection{Treatment of Uncertainties}

Two basic types of uncertainties addressed in this study were parameter value uncertainty and modeling uncertainty. Parameter value uncertainties were evaluated for component rupture probabilities, the conditional probability of core damage given component failures, and human recovery action probabilities. Modeling uncertainty was evaluated for the treatment of the indirect effects of the component failures.

The uncertainties of the component rupture probabilities have been addressed in Vo et al. 1990. For example, the population quartile was chosen to describe uncertainty in the estimates of component rupture probabilities (see Figure 2.2). Limited uncertainty analyses regarding the core damage conditional probabilities have been addressed. The uncertainties in component unavailabilities, initiating event frequencies, and cut set element unavailabilities and their associated modeling were not addressed in this study. Consideration of functional dependencies and common-cause effects on systems were based on the results evaluated by the selected PRAs. The mean parameter values estimated by the PRAs were used to calculate the core damage conditional probabilities. The uncertainties of recovery action errors were addressed in the Surry-1 PRA (Bertucio and Julius 1990). In these evaluations the probabilities were assessed using values of each parameter such that the nth percentile (or quartile) of the uncertainty distribution representing the range over which the true values lie. In this, Monte Carlo or other sampling techniques were used to assess the propagation of parameter value uncertainty through the final results.

There are many variables involved in calculating the indirect effects given a component failure (e.g., location of pipe break, orientation of the equipment, direction of whipping pipe, number of hangers and/or supports, impact location, angle of impacts, etc.). Guidance 


\subsection{Analyses}

provided in the Standard Review Plan 3.6.2 and information obtained through discussions with VEPCO staff during system walkdowns were used to assess the indirect effects. The assessments of the indirect effects using Standard Review Plan 3.6.2 are likely to be conservative. The uncertainty was evaluated by excluding the potential indirect effects of component failures in the model (e.g., pipe whip or jet impingement effects) and recalculating the overall core damage frequency.

\subsubsection{Results of Uncertainty/Sensitivity Analyses}

Sensitivity analyses were performed on issues that could potentially have significant impact on component ranking. The sensitivity analyses addressed the changes in component rankings by using upper- and lower-estimated values of component rupture probabilities as reported in calculations in Vo et al. (1990). As shown in Table 3.1, although variation exists in the numerical results, most components have relatively the same ranking, as compared to the ranking based on the median values. The largest variations in component ranking were the LPI supply lines and sources, pipe segments extending from isolation valves to the steam generator, and pump suction and discharge lines of the AFW system. Pipe segments between the RPV and the RCS loop stop valves have moderate variations in ranking.

Sensitivity analyses were also performed by letting the component rupture probabilities approach 1.0. This causes $P_{c m}$ values to be the same as $P_{c m} \mid P_{s_{i}}$. The new rankings are shown in Table 3.2 (and Figure 3.6). As shown in the table, the RPV components remain on top of the important-component list. This is followed by components within the LPI system, AFW system, and the RCS. The components that had the largest increases in ranking were the LPI source and supply line, ranking second, which is an increase of eight in component ranking. Other components remained at relatively the same rankings. Although probability of failure of the LPI suction line/source is quite low, loss of this component (e.g., loss of common suction lines of the LPI supply line) could disable the entire system, thereby contributing significantly to core damage.

Sensitivity analyses were performed to address contributions to core damage from indirect effects of component failures. The results show that contributions of the indirect effects to the overall core damage frequency are negligible (less than $2 \%$ ). Two pipe segments identified to have potential failure effects on the other systems nearby were 1) the pipe segment between the accumulator discharge line and RCS isolation valve and 2) the pipe segment between LPI pump discharge line and the containment isolation valve. Rupture of the accumulator discharge line could result in a failure of the entire residual heat removal discharge line due to its potential pipe whip and/or jet impingement effects. Similarly, rupture of the LPI pump discharge line could result in disabling of the charging pump inlet header.

Although analyses regarding potential flooding within the plant due to pipe ruptures were not part of this study, the safeguard room at Surry-1 needs to be mentioned. The safeguard room houses the AFW pumps and serves as a pass-through area for the main steam lines and the main feedwater lines. The room also contains three main steam isolation valves, three main steam valves, fifteen steam generator atmospheric dump valves, three steam generator relief valves, one small decay heat relief valve, and three main feedwater check valves. The concern is that a rupture in a pipe segment, a valve body, or a steam-water line could flood the room with steam and/or water, thereby causing all AFW pumps and other safety-related equipment to fail. This is an important issue and will be addressed at the later date. Component risk prioritization of the entire reactor system will be completed and the main steam and main feedwater lines will also be evaluated at a later date. 
Table 3.1. Component Rankings Based on Core Damage Frequency for Four Selected Systems at Surry-1 ${ }^{(a)}$

\begin{tabular}{|c|c|c|c|c|c|}
\hline \multirow{2}{*}{\multicolumn{2}{|c|}{ System - Component ${ }^{(b)}$}} & \multicolumn{3}{|c|}{ Core Damage Frequency } & \multirow{3}{*}{$\frac{\operatorname{Rank}^{(\mathrm{c})}}{1}$} \\
\hline & & \multirow{2}{*}{$\frac{\text { Upper }}{4.00 \mathrm{E}-04}$} & \multirow{2}{*}{$\begin{array}{l}\text { Median } \\
1.58 \mathrm{E}-06 \\
\end{array}$} & \multirow{2}{*}{$\begin{array}{c}\text { Lower } \\
5.40 \mathrm{E}-07 \\
\end{array}$} & \\
\hline RPV - & Beltline Welds & & & & \\
\hline RPV - & Beltline Plate & $1.00 \mathrm{E}-07$ & $1.00 \mathrm{E}-07$ & $8.00 \mathrm{E}-08$ & 2 \\
\hline RPV - & Lower/Bottom Shell & $2.50 \mathrm{E}-07$ & 7.32E-08 & $2.00 \mathrm{E}-08$ & 3 \\
\hline AFW - & CST, Supply Line & $1.60 \mathrm{E}-07$ & $6.86 \mathrm{E}-08$ & $1.60 \mathrm{E}-08$ & 4 \\
\hline RPV - & $\begin{array}{l}\text { Circumferential Flange to Nozzle } \\
\text { Course, Upper Shell, Outside Beltline } \\
\text { Welds }\end{array}$ & $1.30 \mathrm{E}-07$ & $6.16 \mathrm{E}-08$ & $2.00 \mathrm{E}-08$ & 5 \\
\hline LPI-A - & $\begin{array}{l}\text { Pipe Segment Between Accumulator } \\
\text { Discharge Header and RCS Isolation } \\
\text { Valves }\end{array}$ & $1.60 \mathrm{E}-07$ & 4.67E-08 & $3.20 \mathrm{E}-09$ & 6 \\
\hline LPI - & $\begin{array}{l}\text { Pipe Segment Between Containment } \\
\text { Isolation Valve (inside) and Cold Leg } \\
\text { Injection }\end{array}$ & $1.60 \mathrm{E}-07$ & 4.16E-08 & $3.2 \mathrm{E}-08$ & 7 \\
\hline LPI - & $\begin{array}{l}\text { Pipe Segment Between Containment } \\
\text { Isolation Valve (inside) and Cold Leg } \\
\text { Injection }\end{array}$ & $8.70 \mathrm{E}-08$ & $3.80 \mathrm{E}-08$ & $1.40 \mathrm{E}-08$ & 8 \\
\hline LPI - & $\begin{array}{l}\text { LPI Sources (RWST, Sump), Supply } \\
\text { Line }\end{array}$ & $1.86 \mathrm{E}-07$ & $3.64 \mathrm{E}-08$ & $3.20 \mathrm{E}-10$ & 9 \\
\hline LPI - & $\begin{array}{l}\text { Pipe Segment Between Pump Dis- } \\
\text { charge and Containment Isolation } \\
\text { Valve }\end{array}$ & 8.64E-08 & $2.76 \mathrm{E}-08$ & $8.80 \mathrm{E}-09$ & 10 \\
\hline LPI - & $\begin{array}{l}\text { Pipe Segment Between Containment } \\
\text { Isolation Valves }\end{array}$ & $5.44 \mathrm{E}-08$ & $1.46 \mathrm{E}-08$ & $8.00 \mathrm{E}-09$ & 11 \\
\hline RPV - & CRDMs & $2.74 \mathrm{E}-08$ & $5.00 \mathrm{E}-09$ & 2.23E-09 & 12 \\
\hline RPV - & Instrument Lines & $4.18 \mathrm{E}-08$ & $5.00 \mathrm{E}-09$ & $1.58 \mathrm{E}-09$ & 12 \\
\hline AFW - & $\begin{array}{l}\text { Pipe Segment Between Containment } \\
\text { Isolation and SG Isolation Valves }\end{array}$ & $8.00 \mathrm{E}-09$ & 3.33E-09 & $1.52 \mathrm{E}-10$ & 14 \\
\hline AFW - & $\begin{array}{l}\text { Main Steam to AFW Pump Turbine } \\
\text { Drive }\end{array}$ & $8.36 \mathrm{E}-09$ & $2.10 \mathrm{E}-09$ & $2.79 \mathrm{E}-10$ & 15 \\
\hline RCS - & $\begin{array}{l}\text { Pipe Segment Between Loop Stop } \\
\text { Valve and RPV (Cold Leg) }\end{array}$ & $2.70 \mathrm{E}-09$ & $1.60 \mathrm{E}-09$ & $5.34 \mathrm{E}-10$ & 6 \\
\hline
\end{tabular}


Table 3.1 (cont'd)

\begin{tabular}{|c|c|c|c|c|c|}
\hline \multirow{2}{*}{\multicolumn{2}{|c|}{ System - Component $^{(b)}$}} & \multicolumn{3}{|c|}{ Core Damage Frequency } & \multirow{3}{*}{$\frac{\operatorname{Rank}^{(c)}}{17}$} \\
\hline & & \multirow{2}{*}{$\begin{array}{c}\text { Upper } \\
1.59 \mathrm{E}-09\end{array}$} & \multirow{2}{*}{ Median } & \multirow{2}{*}{$\begin{array}{c}\text { Lower } \\
4.48 \mathrm{E}-11 \\
\end{array}$} & \\
\hline LPI - & LPI Pump Suction Line & & & & \\
\hline RCS - & Pressurizer Spray Line & $1.60 \mathrm{E}-09$ & $1.00 \mathrm{E}-09$ & 4.70E-19 & 18 \\
\hline RCS - & $\begin{array}{l}\text { Pipe Segment Between RPV and Loop } \\
\text { Stop Valve (Hot Leg) }\end{array}$ & $2.00 \mathrm{E}-09$ & $5.72 \mathrm{E}-10$ & $3.20 \mathrm{E}-11$ & 19 \\
\hline AFW - & AFW TD Pump Discharge Line & $6.00 \mathrm{E}-10$ & $5.26 \mathrm{E}-10$ & $2.48 \mathrm{E}-11$ & 20 \\
\hline AFW - & $\begin{array}{l}\text { Pipe Segment from Unit } 2 \text { AFW } \\
\text { Pumps }\end{array}$ & $1.39 \mathrm{E}-09$ & $4.18 \mathrm{E}-10$ & $1.39 \mathrm{E}-10$ & 21 \\
\hline AFW - & AFW Isolation Valve to SG & $2.60 \mathrm{E}-10$ & $1.60 \mathrm{E}-10$ & $4.70 \mathrm{E}-12$ & 22 \\
\hline RPV - & Nozzle to Vessel Welds & $3.90 \mathrm{E}-10$ & $6.00 \mathrm{E}-11$ & $1.14 \mathrm{E}-11$ & 23 \\
\hline RPV - & Vessel Studs & $5.00 \mathrm{E}-10$ & $5.00 \mathrm{E}-11$ & $1.58 \mathrm{E}-11$ & 24 \\
\hline AFW - & AFW MDP Suction Line & $1.39 \mathrm{E}-(19$ & 4.27E-11 & $2.79 \mathrm{E}-11$ & 25 \\
\hline AFW - & AFW MDP Discharge Line & $5.41 \mathrm{E}-11$ & 3.95E-11 & $4.92 \mathrm{E}-12$ & 26 \\
\hline RPV - & Upper, Closure Head, Flange & $5,71 \mathrm{E}-11$ & $3.58 \mathrm{E}-11$ & $5.71 \mathrm{E}-12$ & 27 \\
\hline RPV - & Nozzle Forging Inlet/Outlet & $2.50 \mathrm{E}-11$ & $2.50 \mathrm{E}-11$ & $5.00 \mathrm{E}-12$ & 28 \\
\hline AFW - & AFW TDP Suction Line & $4.37 \mathrm{E}-11$ & $1.51 \mathrm{E}-11$ & $5.41 \mathrm{E}-12$ & 29 \\
\hline AFW - & $\begin{array}{l}\text { Pipe Segment from Emergency Make- } \\
\text { up System, Fire Main }\end{array}$ & $2.46 \mathrm{E}-11$ & $5.71 \mathrm{E}-12$ & $2.46 \mathrm{E}-12$ & 30 \\
\hline RCS - & Pressurizer Relief/Safety Line & $7.00 \mathrm{E}-12$ & $2.26 \mathrm{E}-12$ & 2.35E-13 & 31 \\
\hline RCS - & Pressurizer Surge Line & $2.23 \mathrm{E}-12$ & $9.15 \mathrm{E}-13$ & $3.05 \mathrm{E}-13$ & 32 \\
\hline LPI-A & Accumulator Discharge Line & $5.56 \mathrm{E}-13$ & $9.09 \mathrm{E}-14$ & 3.47E-14 & 33 \\
\hline RCS - & Pipe Segment Between SG and RCP & $3.05 E-13$ & $6.10 \mathrm{E}-14$ & $1.83 \mathrm{E}-14$ & 34 \\
\hline RCS - & $\begin{array}{l}\text { Pipe Segment Between Loop Stop } \\
\text { Valve and SG (Hot Leg) }\end{array}$ & $2.44 \mathrm{E}-13$ & $4.30 \mathrm{E}-14$ & $1.83 E-14$ & 35 \\
\hline RCS - & $\begin{array}{l}\text { Pipe Segment Between RCP and Loop } \\
\text { Stop Valve (Cold Leg) }\end{array}$ & $1.52 \mathrm{E}-13$ & $2.36 \mathrm{E}-14$ & $6.10 \mathrm{E}-15$ & 36 \\
\hline LPI-A - & Accumulator, Suction Line & $3.47 \mathrm{E}-14$ & $1.60 \mathrm{E}-14$ & $3.47 \mathrm{E}-15$ & 37 \\
\hline
\end{tabular}

(a) Based on the estimated median values of component rupture probabilities.

(b) $\quad$ RPV = Reactor Pressure Vessel; AFW = Auxiliary Ieedwater; L.PI = Low Pressure Injection; I.PI-A = Low Pressure InjectionAccumulator; $R C S=$ Reactor Coolant System.

(c) Rankings were based on "Median" values. 
Table 3.2. Component Rankings Based on Conditional Core Damage Frequency Given a Component Rupture ${ }^{(a)}$ for Selected

Systems at Surry-1

\begin{tabular}{|c|c|c|c|}
\hline & System-Component ${ }^{(\mathrm{b})}$ & $\begin{array}{l}\text { Core Damage } \\
\text { Frequency }\end{array}$ & Rank \\
\hline RPV - & Beltline Welds & 1.0 & 1 \\
\hline RPV - & Beltline Plate & 1.0 & 1 \\
\hline RPV - & Lower/Bottom Shell & 1.0 & 1 \\
\hline AFW - & CST, Supply Line & $1.70 \mathrm{E}-02$ & 9 \\
\hline RPV - & $\begin{array}{l}\text { Circumferential Flange to Nozzle Course, Upper Shell, } \\
\text { Outside Bellline Welds }\end{array}$ & 1.0 & 1 \\
\hline LP!-A - & $\begin{array}{l}\text { Pipe Segment Between Accumulator Discharge Header and } \\
\text { RCS Isolation Valves }\end{array}$ & $1.80 \mathrm{E}-02$ & 8 \\
\hline LPI - & $\begin{array}{l}\text { Pipe Segment Between Containment Isolation Valve (inside) } \\
\text { and Cold-Leg Injection }\end{array}$ & $1.60 \mathrm{E}-02$ & 10 \\
\hline LPI - & $\begin{array}{l}\text { Pipe Segment Between Containment Isolation Valve (inside) } \\
\text { and Hot-Leg Injection }\end{array}$ & $3.00 \mathrm{E}-02$ & 6 \\
\hline LPI - & LPI Sources (RWST, Sump), Supply Line & $3.64 \mathrm{E}-02$ & 5 \\
\hline LPI - & $\begin{array}{l}\text { Pipe Segment Between Pump Discharge and Containment } \\
\text { Iso. Valve }\end{array}$ & $2.00 \mathrm{E}-02$ & 7 \\
\hline LPI - & Pipe Segment Between Containment Isolation Valves & $1.20 \mathrm{E}-02$ & 11 \\
\hline RPV - & CRDMs & $5.00 \mathrm{E}-04$ & 19 \\
\hline RPV - & Instrument Lines & $5.00 \mathrm{E}-04$ & 19 \\
\hline AFW - & $\begin{array}{l}\text { Pipe Segment Between Containment Isolation and SG Isola- } \\
\text { tion Valves }\end{array}$ & $4.00 \mathrm{E}-04$ & 27 \\
\hline AFW - & Main Steam to AFW Pump Turbine Drive & $1.60 \mathrm{E}-04$ & 31 \\
\hline RCS - & $\begin{array}{l}\text { Pipe Segment Between Loop Stop Valve and RPV (Cold } \\
\text { Leg) }\end{array}$ & $1.10 \mathrm{E}-02$ & 12 \\
\hline LPI - & LPI Pump Suction Line & $1.40 \mathrm{E}-03$ & 17 \\
\hline RCS - & Pressurizer Spray Line & $1.00 \mathrm{E}-04$ & 18 \\
\hline RCS - & Pipe Segment Between RPV and Loop Stop Valve (Hot Leg) & $2.90 \mathrm{E}-03$ & 14 \\
\hline AFW - & AFW TD Pump Discharge Line & $2.30 \mathrm{E}-04$ & 30 \\
\hline AFW - & Pipe Segment from Unit 2 AFW Pumps & $1.40 \mathrm{E}-04$ & 32 \\
\hline
\end{tabular}


Table 3.2 (cont'd)

\begin{tabular}{|l|l|c|c||}
\hline \multicolumn{1}{|c|}{ System-Component ${ }^{(\mathrm{b})}$} & $\begin{array}{c}\text { Core Damage } \\
\text { Frequency }\end{array}$ & Rank \\
\hline AFW - & AFW Isolation Valve to SG & $2.60 \mathrm{E}-04$ & 29 \\
\hline RPV - & Nozzle to Vessel Welds & $3.00 \mathrm{E}-03$ & 13 \\
\hline RPV - & Vessel Studs & $5.00 \mathrm{E}-04$ & 19 \\
\hline AFW - & AFW MDP Suction Line & $1.20 \mathrm{E}-05$ & 34 \\
\hline AFW - & AFW MDP Discharge Linc & $1.70 \mathrm{E}-05$ & 33 \\
\hline RPV - & Upper, Closure Head, Flange & $1.80 \mathrm{E}-03$ & 15 \\
\hline RPV - & Nozzle Forging Inlet/Outlet & $1.30 \mathrm{E}-03$ & 16 \\
\hline AFW - & AFW TDP Suction Line & $4.00 \mathrm{E}-05$ & 28 \\
\hline AFW - & Pipe Segment from Emergency Makeup System, Fire Main & $3.90 \mathrm{E}-06$ & 36 \\
\hline RCS - & Pressurizer Relief/Safety Line & $5.00 \mathrm{E}-04$ & 19 \\
\hline RCS - & Pressurizer Surge Line & $5.00 \mathrm{E}-04$ & 19 \\
\hline LPI-A - & Accumulator Discharge Line & $1.00 \mathrm{E}-05$ & 33 \\
\hline RCS - & Pipe Segment Between SG and RCP & $5.00 \mathrm{E}-04$ & 19 \\
\hline RCS - & Pipe Segment Between Loop Stop Valve and SG (Hot Leg) & $5.00 \mathrm{E}-04$ & 19 \\
\hline RCS - & $\begin{array}{l}\text { Pipe Segment Between RCP and Loop Stop Valve (Cold } \\
\text { Leg) }\end{array}$ & $5.00 \mathrm{E}-04$ & 19 \\
\hline LPI-A - & Accumulator, Suction Line & $2.10 \mathrm{E}-07$ & 37 \\
\hline
\end{tabular}

(a) Based on the estimated median values of component rupture probabilities.

(b) $\quad$ RPV $=$ Reactor Pressure Vessel; AFW = Auxiliary Feedwater; LPI = Low Pressure Injection; LPI-A = Low Pressure InjectionAccumulator; $\mathrm{RCS}=$ Reactor Coolant System. 
Table 3.3. Risk Importance Parameters for Components at Selected Systems at Surry-1 ${ }^{(a)}$

\begin{tabular}{|c|c|c|c|c|}
\hline System-Component ${ }^{(\mathrm{b})}$ & Rank & $\begin{array}{l}\text { Conditional } \\
\text { Core Damage } \\
\text { Frequency } \\
\text { Given Rupture }\end{array}$ & $\begin{array}{l}\text { Rupture } \\
\text { Frequency }\end{array}$ & $\begin{array}{l}\text { Core } \\
\text { Damage } \\
\text { Frequency }\end{array}$ \\
\hline RPV - Beltline Region Welds & 1 & 1.0 & $1.58 \mathrm{E}-06$ & $1.58 \mathrm{E}-06$ \\
\hline RPV - Beltline Plate & 2 & 1.0 & $1.00 \mathrm{E}-07$ & $1.00 \mathrm{E}-07$ \\
\hline RPV - Lower/Bottom Shell & 3 & 1.0 & 7.32E-08 & 7.32E-08 \\
\hline AFW - CST, Supply Line & 4 & $1.7 \mathrm{E}-02$ & 4.03E-06 & $6.86 \mathrm{E}-08$ \\
\hline $\begin{array}{l}\text { RPV - Circumferential Flange to Nozzle } \\
\text { Course Upper Shell, Outside Beltline } \\
\text { Welds }\end{array}$ & 5 & 1.0 & $6.16 \mathrm{E}-08$ & $6.16 \mathrm{E}-08$ \\
\hline $\begin{array}{l}\text { LPI-A - Pipe Segment Between Accumu- } \\
\text { lator Discharge Header and RCS Isola- } \\
\text { tion Valves }\end{array}$ & 6 & $1.8 \mathrm{E}-02$ & $2.59 \mathrm{E}-06$ & 4.67E-08 \\
\hline $\begin{array}{l}\text { LPI - Pipe Segment Between Contain- } \\
\text { ment Isolation Valve (inside) and Cold } \\
\text { Leg Injection }\end{array}$ & 7 & $3.2 \mathrm{E}-02$ & $1.30 \mathrm{E}-06$ & 4.16E-08 \\
\hline $\begin{array}{l}\text { LPI - Pipe Segment Between Contain- } \\
\text { ment Isolation Valve (inside) and Hot } \\
\text { Leg Injection }\end{array}$ & 8 & $3.20 \mathrm{E}-02$ & $1.19 \mathrm{E}-05$ & $3.80 \mathrm{E}-08$ \\
\hline $\begin{array}{l}\text { LPI - LPI Sources (RWST, Sump), Sup- } \\
\text { ply Line }\end{array}$ & 9 & $3.64 \mathrm{E}-02$ & $1.00 \mathrm{E}-06$ & 3.64E-08 \\
\hline $\begin{array}{l}\text { LPI - Pipe Segment Between Pump Dis- } \\
\text { charge and Containment Isolation Valve }\end{array}$ & 10 & $3.2 \mathrm{E}-02$ & $8.63 \mathrm{E}-07$ & $2.76 \mathrm{E}-08$ \\
\hline $\begin{array}{l}\text { LPI - Pipe Segment Between Contain- } \\
\text { ment Isolation Valves }\end{array}$ & 11 & $1.6 \mathrm{E}-02$ & $9.13 \mathrm{E}-07$ & $1.46 \mathrm{E}-08$ \\
\hline RPV - CRDMs & 12 & $5.0 \mathrm{E}-04$ & $1.00 \mathrm{E}-05$ & $5.00 \mathrm{E}-09$ \\
\hline RPV - Instrument Lines & 13 & $5.0 \mathrm{E}-04$ & $1.00 \mathrm{E}-05$ & $5.00 \mathrm{E}-09$ \\
\hline $\begin{array}{l}\text { AFW - Pipe Segment Between Contain- } \\
\text { ment Isolation and SG Isolation Valves }\end{array}$ & 14 & $8.49 E-05$ & $3.92 \mathrm{E}-05$ & 3.33E-09 \\
\hline $\begin{array}{l}\text { AFW - Main Steam to AFW Pump Tur- } \\
\text { bine Drive }\end{array}$ & 15 & $1.64 \mathrm{E}-04$ & $1.28 \mathrm{E}-05$ & 2.10E-09 \\
\hline $\begin{array}{l}\text { RCS - Pipe S:gment Between Loop Stop } \\
\text { Valve and RPV (Cold Leg) }\end{array}$ & 16 & $1.13 \mathrm{E}-02$ & $1.42 \mathrm{E}-07$ & $1.60 \mathrm{E}-09$ \\
\hline
\end{tabular}


Table 3.3 (cont'd)

\begin{tabular}{|c|c|c|c|c|}
\hline System-Component ${ }^{(\mathrm{b})}$ & Rank & $\begin{array}{l}\text { Conditional } \\
\text { Core Damage } \\
\text { Frequency } \\
\text { Given Rupture }\end{array}$ & $\begin{array}{l}\text { Rupture } \\
\text { Frequency }\end{array}$ & $\begin{array}{c}\text { Core } \\
\text { Damage } \\
\text { Frequency }\end{array}$ \\
\hline LPI - LPI Pump Suction Line & 17 & $1.36 \mathrm{E}-03$ & $1.10 \mathrm{E}-06$ & $1.50 \mathrm{E}-09$ \\
\hline RCS - Pressurizer Spray Line & 18 & $1.0 \mathrm{E}-04$ & $1.00 \mathrm{E}-05$ & $1.00 \mathrm{E}-09$ \\
\hline $\begin{array}{l}\text { RCS - Pipe Segment Between RPV and } \\
\text { Loop Stop Valve (Hot Leg) }\end{array}$ & 19 & $2.86 \mathrm{E}-03$ & $2.00 \mathrm{E}-07$ & $5.72 \mathrm{E}-10$ \\
\hline AFW - AFW TD Pump Discharge Line & 20 & $5.2 \mathrm{E}-05$ & $1.02 \mathrm{E}-05$ & $5.26 \mathrm{E}-10$ \\
\hline $\begin{array}{l}\text { AFW - Pipe Segment from Unit } 2 \text { AFW } \\
\text { Pumps }\end{array}$ & 21 & $1.4 \mathrm{E}-04$ & $2.98 \mathrm{E}-06$ & 4.18E-10 \\
\hline AFW - AFW Isolation Valve to SG & 22 & $2.46 \mathrm{E}-06$ & $6.51 \mathrm{E}-05$ & $1.60 \mathrm{E}-10$ \\
\hline RPV - Nozzle to Vessel Welds & 23 & $3.0 \mathrm{E}-03$ & $2.00 \mathrm{E}-08$ & $6.00 \mathrm{E}-11$ \\
\hline RPV - Vessel Studs & 24 & $5.0 \mathrm{E}-04$ & $1.00 \mathrm{E}-07$ & $5.00 \mathrm{E}-11$ \\
\hline AFW - AFW MDP Suction Line & 25 & $1.2 \mathrm{E}-05$ & $3.55 \mathrm{E}-06$ & 4.27E-11 \\
\hline AFW - AFW MDP Discharge Line & 26 & $1.65 \mathrm{E}-05$ & 2.39E-06 & 3.95E-11 \\
\hline RPV - Upper, Closure Head, Flange & 27 & $1.79 \mathrm{E}-03$ & $2.00 \mathrm{E}-08$ & $3.58 \mathrm{E}-11$ \\
\hline RPV - Nozzle Forging Inlet/Outlet & 28 & $1.25 \mathrm{E}-03$ & $2.00 \mathrm{E}-08$ & $2.50 \mathrm{E}-11$ \\
\hline AFW - AFW TDP Suction Line & 29 & $2.47 \mathrm{E}-06$ & $6.12 \mathrm{E}-06$ & $1.51 \mathrm{E}-11$ \\
\hline $\begin{array}{l}\text { AFW - Pipe Segment from Emergency } \\
\text { Makeup System, Fire Main }\end{array}$ & 30 & $3.9 \mathrm{E}-06$ & $1.46 \mathrm{E}-06$ & $5.71 \mathrm{E}-12$ \\
\hline RCS - Pressurizer Relief/Safety Line & 31 & 3.53E-07 & $6.14 \mathrm{E}-06$ & $2.26 \mathrm{E}-12$ \\
\hline RCS - Pressurizer Surge Line & 32 & $1.5 \mathrm{E}-06$ & $6.1 \mathrm{E}-07$ & $9.15 \mathrm{E}-13$ \\
\hline LPI-A - Accumulator Discharge Line & 33 & $3.5 \mathrm{E}-08$ & $2.0 \mathrm{E}-07$ & $9.09 \mathrm{E}-14$ \\
\hline $\begin{array}{l}\text { RCS - Pipe Segment Between SG and } \\
\text { RCP }\end{array}$ & 34 & $3.05 \mathrm{E}-07$ & 2.0E-07 & $6.10 \mathrm{E}-14$ \\
\hline $\begin{array}{l}\text { RCS - Pipe Segment Between Loop Stop } \\
\text { Valve and SG (Hot Leg) }\end{array}$ & 35 & 3.05E-07 & $1.41 \mathrm{E}-07$ & $4.30 \mathrm{E}-14$ \\
\hline $\begin{array}{l}\text { RCS - Pipe Segment Between RCP and } \\
\text { Loop Stop Valve (Cold Leg) }\end{array}$ & 36 & $3.05 \mathrm{E}-07$ & 7.75E-08 & $2.36 \mathrm{E}-14$ \\
\hline LPI-A - Accumulator, Suction Line & 37 & 3.5E-08 & 4.57E-07 & $1.60 \mathrm{E}-14$ \\
\hline
\end{tabular}

(a) Based on the estimated median values.

(b) $\quad$ RPV $=$ Reactor Pressure Vessel; AFW = Auxiliary Feedwater; LPI = Low Pressure Injection; LPI-A = Low Pressure InjectionAccumulator; RCS = Reactor Coolant System. 


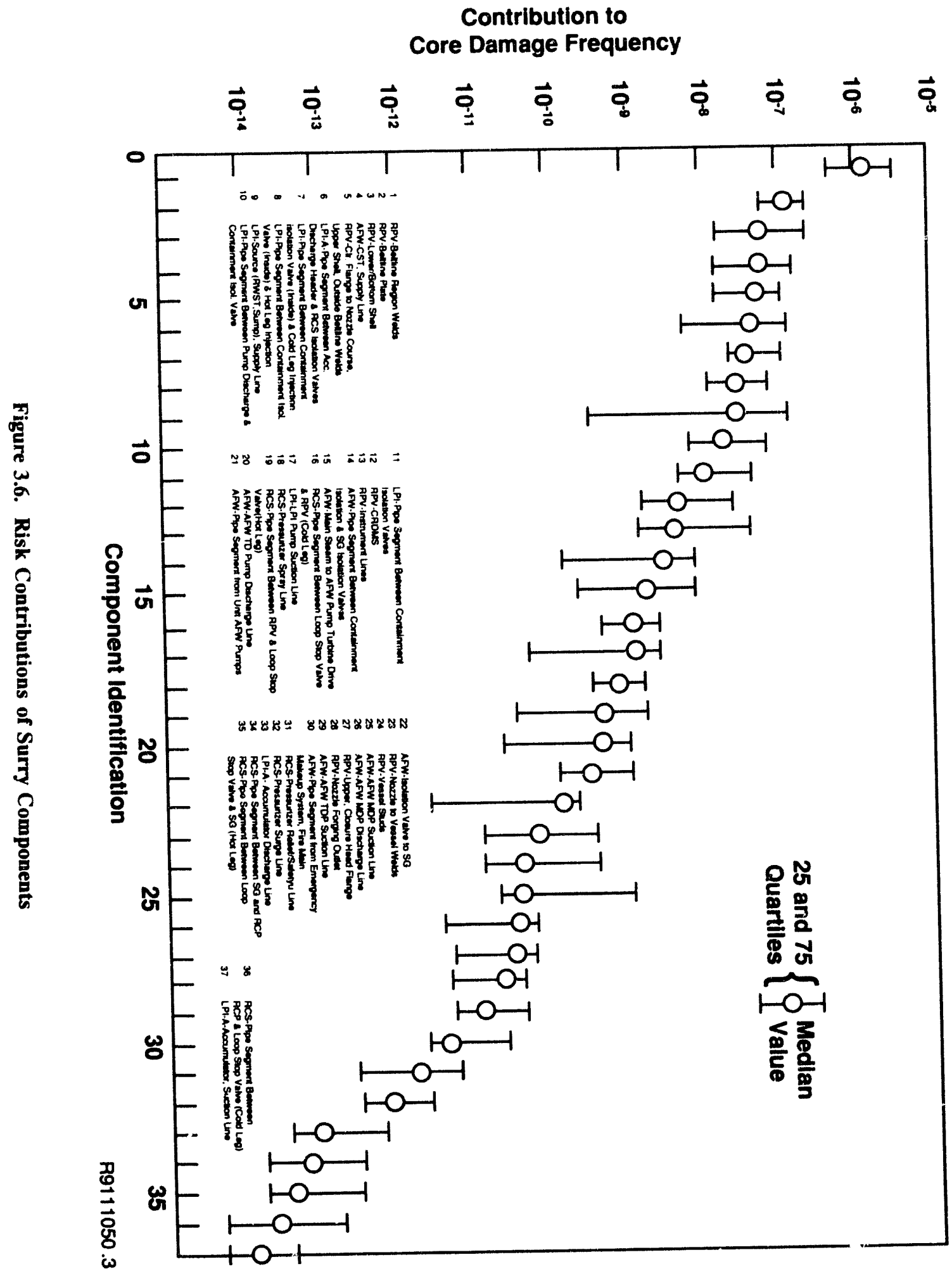




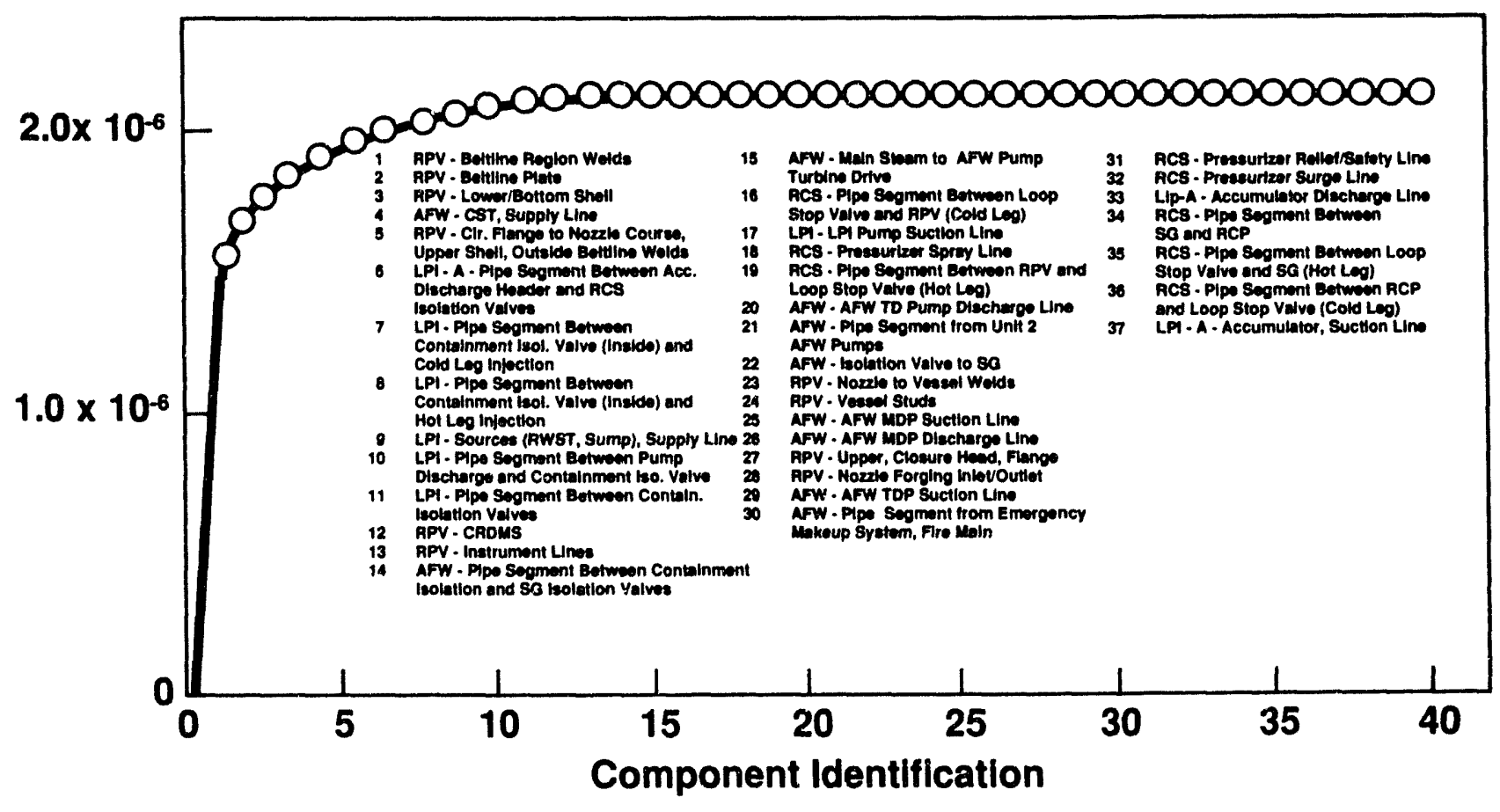

$\mathrm{R} 9108092.4$

Figure 3.7. Cumulative Risk Contributions for Surry-1 Components 


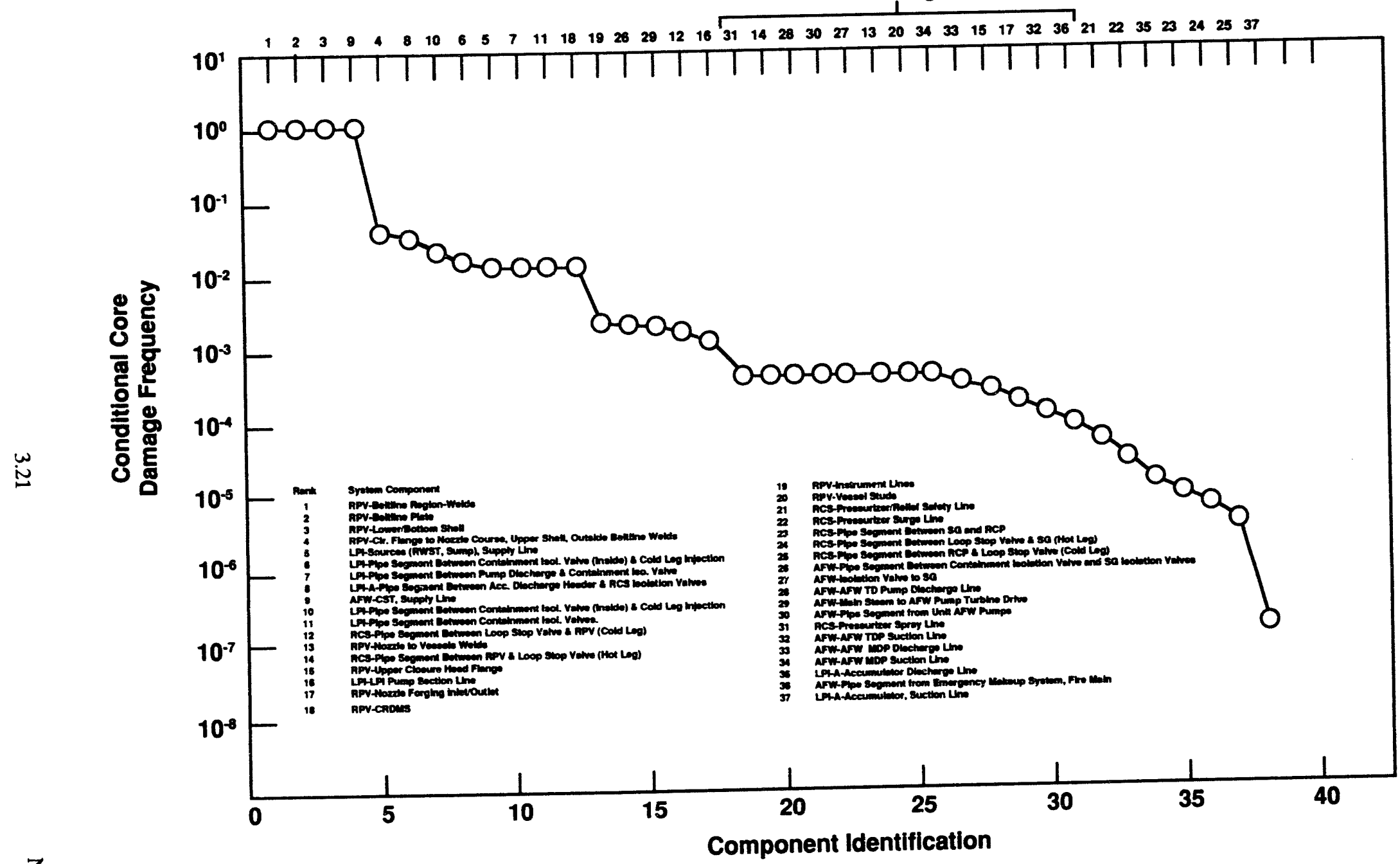




\subsection{Discussions of the Results}

This section discusses the results presented in Section 3.0. Proposed values of target risk and rupture probability are also discussed. The discussions are based on the estimated median parameter values.

\subsection{Ranking of Component Risk}

The rankings of Table 3.1 were developed on the basis of core damage frequency. In this discussion we will identify the factors that govern these rankings, beginning with the highest ranked components and ending with the lowest ranked components.

For discussion purposes, "high-risk importance components" refer to components that have core damage frequency between $1.00 \mathrm{E}-08$ and $>1.00 \mathrm{E}-06$. Similarly, "medium-risk importance components" refer to those components having core damage frequencies of $1.00 \mathrm{E}$ 10 to $1.00 \mathrm{E}-08$. "Low-risk importance components" refer to those components having core damage frequencies less than $1.00 \mathrm{E}-10$.

\subsubsection{High-Risk Importance Components}

The most risk-important components are located within the beltline region of the reactor vessel. The importance of this region is due to high neutron fluence and associated embrittlement levels, in conjunction with the high consequence (core damage) resulting from structural failure. The critical welds were identified on the basis of concerns with pressurized thermal shock for the Surry-1 vessels (Heinecke et al. 1987). Given a catastrophic failure within the beltline region, core damage is certain. The lower and bottom shell portions of the reactor vessel were also important but had somewhat lower rankings due to the lower estimated rupture probabilities of these components (e.g., lower fluence and embrittlement levels). The circumferential flangeto-nozzle course welds, upper shell welds, and welds outside the beltline region of the pressure vessel had still lower rankings but were identified to be important. Although these components have lower neutron fluence and lower embrittlement levels, failures of these components also have high core damage consequences.

High-risk importance (approaching RPV components) for the AFW system supply lines and sources (e.g., condensate storage tanks) was due to relatively active failure mechanisms (e.g., corrosion). Although these components have relatively low pressures, failure of these components would disable the entire AFW system, and thus contribute significantly to core damage.

Relatively high rankings were estimated for the pipe segments of the LPI-Accumulator system extending from the accumulator discharge headers to the RCS isolation valves. The high rankings of these lines are due to their important safety functions in providing coolant to the RCS following an accident. Because the residual heat removal (RHR) system is connected to these lines, ruptures of these lines could prevent cooling water from being supplied to the RCS loops during the plant shutdown or cooldown.

Pipe segments of the LPI system extending from the inside containment isolation valves to the RCS coldand hot-leg injection headers were also identified to be high risk-important components. The high rankings are due to relatively high stresses, potential for overpressurization of these lines, and the important functions of these lines in providing coolant to the PCS following a large LOCA. A high risk importance is also noted for the LPI supply lines and water sources (e.g., refueling water storage tank and containment sump). Failures of these lines result in a total loss of the LPI system. The LPI pump discharge lines up to the containment isolation valves follow in risk importance due to either lower stresses and/or lower core damage consequences resulting from component ruptures. Depending on the break location, ruptures of these lines result in an interfacing system LOCA outside the containment.

\subsubsection{Medium-Risk Importance Components}

The control rod drive mechanisms (CRDMs) and instrument lines of the reactor vessel are next in ranking. These components have much lower estimated consequences of failures compared with other RPV components. The failure consequences were estimated in the worst case to be equivalent to a large LOCA. Equal importance was estimated for the pipe segments of the AFW system extending from the containment isolation valves to the steam generator isolation valves, and also the pipe segments extending from steam supply lines to the AFW pump curbine drive. The importance of these lines is due to a combination of high stress and high system unavailability resulting from a line rupture. 
As shown in Table 3.1, the next most important segments are the main RCS piping from the cold-leg loop stop valves to the pressure vessel, the pressurizer spray piping, and the pipe segments from the pressure vessel to the hot-leg loop stop valves. Failure of any of these lines results in a large LOCA which cannot be isolated by the loop stop values, as is the case with other segments of the main RCS piping. High estimated consequences resulting from lines being connected to the RCS loop (e.g., safety injection, RHR lines, etc.) increase the importance of these particular pipe segments within the reactor coolant loop. The importance of the pressurizer spray line results from a relatively highestimated failure probability due to thermal stresses and the key function of this line in controlling the desired primary system pressure. Failure of the spray line could result in LOCAs in Loops $A$ and $C$, in addition to the loss of the pressurizer function.

Of equal importance in Table 3.1 are the pump suction lines of the LPI system, the AFW turbine-driven pump discharge lines, the Unit 2 AFW pump cross-connected line, and the pipe segments extending from the AFW isolation valves to the steam generators. Ruptures of the LPI pump suction lines would prevent the borated water from being supplied to the RCS when needed. Similarly, a break in the AFW turbine-driven pump discharge line could prevent sufficient cooling water from being supplied to the steam generators. Unless appropriate recovery actions are taken, a complete loss of water supply to the steam generators may result, contributing significantly to core damage. The importance of the Unit 2 AFW pump cross-connected line is due to its key function in providing cooling to the steam generators in the case that Unit $1 \mathrm{AFW}$ is lost. This cross-connected line is used for mitigating other initiating events as well (e.g., station blackout). Finally, failures of the pipe segments extending from the AFW isolation valves to the steam generators would result in steam generator blowdown through the break (similar to a main steam line break) and a loss of secondary cooling.

\subsubsection{Low-Risk Importance Components}

Lower importances are noted for the RPV nozzle to vessel welds, vessel studs, the RPV upper closure head and flanges, and the RPV nozzle forging (inlet and outlet). The failure consequences of these components were estimated in the worst case to be equivalent to a large LOCA. The AFW motor-driven pump suction and discharge lines, the turbine-driven pump suction line, the pipe segments from the emergency makeup system, and the fire main were estimated to have relatively low rankings. This is due mainly to the low estimated consequences for failures of these components.

Of the 37 components ranked in Table 3.1, the following were identified to have the lowest importance: the pressurizer relief and safety lines, pressurizer surge line, pipe segments extending from the hot-leg loop stop valve to the steam generator, pipe segments extending from the coolant pump to the cold-leg loop stop valve of the RCS, and the accumulator discharge and suction lines. These low rankings are due to low rupture probability estimates and/or low core damage consequence estimates for these components. Additionally, failures of the lines within the RCS loops, at most, will result in a large LOCA which can be isolated by the loop stop values.

The cumulative risk contribution for all 37 components of the four systems (as shown in Figure 3.6) is about 2.1E-06 per plant year. Significant contributions to risk come only from failures of approximately the first 10 components. The welds of the beltline region of the reactor pressure vessel dominate the risk, accounting for almost $75 \%$ of the core damage frequency due to component failures. The beltline welds are followed in importance by the beltline plate material, which accounts for another 5\%. The welds in the upper and lower reactor heads account for another $6 \%$; the single AFW condensate storage tank and supply line contribute 3\%; and various welds in the LPI system contribute another $10 \%$ ). This adds up to more than $99 \%$ of the total core damage frequency risk associated with component ruptures for the four system analyzed. The system level rankings derived from component contributions to core damage are the following: 1) RPV, 2) LPI, 3) AFW, and 4) RCS. These results agree with those obtained from the earlier PNL system-level study (Vo et al. 1989).

Table 4.1 presents the Surry-1 plant-specific ASME classifications and required ISI examinations for each piping section or component of Table 3.1. Table 4.1 shows that ASME classifications and ISI requirements are in general agreement with the importance rankings based on core damage frequency. In particular, the 
RPV component making the greatest contribution to the core damage frequency has the most stringent inspection requirements. However, recommendations for setting inspection requirements based solely on Table 4.1 should be made cautiously because additional plant systems will be considered in future PNL work.

\subsection{Development of Target Risk and Rupture Probability Values}

A philosophy and approach for selecting target risk values and target rupture probabilities has been recommended by the ASME Research Task Force on RiskBased Inspection. The philosophy is that the inspection should ensure that the risk of core damage resulting from pressure boundary and structural failures should be a small fraction of the total core damage risk estimated in the plant specific PRAs. The ranking process described in this report can be used to set priorities for inspection but does not provide criteria for determining the degree of inspection. For this purpose, the risk due to pressure boundary and structural failures is herein referred to as the "target risk," and $5 \%$ of the total PRA estimated risk from internal events has been recommended as an appropriate value. It is further recommended that this target risk be apportioned unequally among the risk-important components by considering the estimated risk associated with rupture of each component (Gore, et al. 1991). Using the results of conditional probability of core damage given component failures, then, the target rupture probabilities for components can be estimated.

The core damage frequency estimated in state-of-the-art PRAs for modern facilities is about 5.0E-05 per plant year. Using this number, an appropriate target risk value to be distributed among the components would be 2.5E-06 per plant year (i.e., 5\% of the total PRA risk).
Examination of Table 3.1 shows that the total risk for the four systems analyzed is about $2.1 \mathrm{E}-06$ per plant year, which is rather close to the total recommended target risk of 2.5E-06 per plant year. Thus, the total target risk in this case is essentially the same as the total estimated risk due to ruptures. However, analysis of the remaining systems at Surry-1 may increase this total risk until it may equal or exceed the total recommended target risk.

The recommendation that the target risk be apportioned on the basis of the component's estimated risk, in this case, means that the target risk values can be set equal to the component's estimated risk. This, in turn, means that the target rupture probability for each component can be the same as the rupture probability estimated by the expert judgment elicitation panel (since consequences are fixed by the PRA analysis given that a rupture occurs). Table 3.3 of Section 3.0 shows the rupture probabilities for components of Table 3.1. For example, the beltline region of the Surry-1 RPV contains five welds (four longitudinal welds and one circumferential weld). The per-weld rupture probability was estimated as $3.16 \mathrm{E}-07$, and the estimated target risk for all five welds was 1.58E-06 (Table 3.1). Based on the above discussions, the value of $3.17 \mathrm{E}-07$ can be used as a desired target rupture probability for each weld within the RPV beltline region.

Following this approach, the objective of ISI is to provide confidence that the failure probabilities do remain at or below the values estimated by the expert elicitation. In those cases where the total risk for all components exceeds target values (e.g., 2.5E-06 per plant year), and an additional objective of ISI should be the reduction of failure probabilities for selected components. 
Table 4.1. Component Importance Compared with ASME BPVC Section XI Classifications and ISI Requirements for Selected Systems at Surry-1 ${ }^{(a)}$

\begin{tabular}{|c|c|c|c|}
\hline \multirow{2}{*}{\multicolumn{2}{|c|}{ System-Component }} & \multicolumn{2}{|c|}{ ASME BPVC System } \\
\hline & & \multirow{2}{*}{ Category } & \multirow{2}{*}{$\begin{array}{l}\text { Examination } \\
\text { Volumetric } \\
\end{array}$} \\
\hline RPV & Beltline Welds & & \\
\hline RPV & Beltline Plate & B-A & Volumetric \\
\hline RPV & Lower/Bottom Shell & B-A & Volumetric \\
\hline AFW & CST, Supply Line & D-B & Visual \\
\hline RPV & $\begin{array}{l}\text { Circumferential Flange to Nozzle Course, Upper } \\
\text { Shell, Outside Beltline Welds }\end{array}$ & B-A & Volumetric \\
\hline LPI-A & $\begin{array}{l}\text { Pipe Segment Between Accumulator Discharge } \\
\text { Header and RCS Isolation Valves }\end{array}$ & B-I & $\begin{array}{l}\text { Volumetric and } \\
\text { Surface }\end{array}$ \\
\hline LPI & $\begin{array}{l}\text { Pipe Segment Between Containment Isolation Valve } \\
\text { (inside) and Cold-Leg Injection }\end{array}$ & B-J, C-F-1 & $\begin{array}{l}\text { Volumetric and } \\
\text { Surface }\end{array}$ \\
\hline LPI & $\begin{array}{l}\text { Pipe Segment Between Containment Isolation Valve } \\
\text { (inside) and Hot-Leg Injection }\end{array}$ & B-J, C-F-1 & $\begin{array}{l}\text { Volumetric and } \\
\text { Surface }\end{array}$ \\
\hline LPI & LPI Sources (RWST, Sump), Supply Line & $\mathrm{D}-\mathrm{C}$ & Visual \\
\hline LPI & $\begin{array}{l}\text { Pipe Segment Between Pump Discharge and Con- } \\
\text { tainment Isolation Valve }\end{array}$ & C-F-1 & $\begin{array}{l}\text { Volumetric and } \\
\text { Visual }\end{array}$ \\
\hline LPI & Pipe Segment Between Containment Isolation Valves & $\mathrm{C}-\mathrm{F}-1$ & $\begin{array}{l}\text { Volumetric and } \\
\text { Visual }\end{array}$ \\
\hline RPV & CRDMs & B-E & Visual \\
\hline RPV & Instrument Lines & B-J & Exempt \\
\hline AFW & $\begin{array}{l}\text { Pipe Segment Between Containment Isolation and } \\
\text { SG Isolation Valves }\end{array}$ & $C-F-1$ & $\begin{array}{l}\text { Volumetric and } \\
\text { Surface }\end{array}$ \\
\hline AFW & Main Steam to AFW Pump Turbine Drive & C-F-1, & Volumetric, \\
\hline RCS & $\begin{array}{l}\text { Pipe Segment Between Loop Stop Valve and RPV } \\
\text { (Cold Leg) }\end{array}$ & B-J & Volumetric \\
\hline LPI & LPI Pump Suction Line & C-F-1 & $\begin{array}{l}\text { Volumetric and } \\
\text { Surface }\end{array}$ \\
\hline RCS & Pressurizer Spray Line & B-J & Volumetric \\
\hline RCS & $\begin{array}{l}\text { Pipe Segment Between RPV and Loop Stop Valve } \\
\text { (Hot Leg) }\end{array}$ & B-J & Volumetric \\
\hline
\end{tabular}


Table 4.1 (cont'd)

\begin{tabular}{|c|c|c|c|}
\hline \multirow{2}{*}{\multicolumn{2}{|c|}{ System-Component }} & \multicolumn{2}{|c|}{ ASME BPVC System } \\
\hline & & \multirow{2}{*}{$\frac{\text { Category }}{\text { D-B }}$} & \multirow{2}{*}{$\begin{array}{l}\text { Examination } \\
\text { Visual } \\
\end{array}$} \\
\hline AFW & AFW TD Pump Discharge Line & & \\
\hline AFW & Pipe Segment from Unit 2 AFW Pumps & C-F-1, & Volumetric \\
\hline AFW & AFW Isolation Valve to SG & $C-F-1$ & $\begin{array}{l}\text { Volumetric and } \\
\text { Surface }\end{array}$ \\
\hline RPV & Nozzle to Vessel Welds & B-D & Volumetric \\
\hline RPV & Vessel Studs & B-G-1 & $\begin{array}{l}\text { Volumetric, } \\
\text { Surface, and Vi- } \\
\text { sual }\end{array}$ \\
\hline AFW & AFW MDP Suction Line & D-B & Visual \\
\hline AFW & AFW MDP Discharge Line & D-B & Visual \\
\hline RPV & Upper, Closure Head, Flange & B-A & $\begin{array}{l}\text { Volumetric and } \\
\text { Surface }\end{array}$ \\
\hline RPV & Nozzle Forging Inlet/Outlet & B-D & Volumetric \\
\hline AFW & AFW TDP Suction Line & D-B & Visual \\
\hline AFW & $\begin{array}{l}\text { Pipe Segment from Emergency Makeup System, Fire } \\
\text { Main }\end{array}$ & D-B & Visual \\
\hline RCS & Pressurizer Relief/Safety Line & B-J & Volumetric \\
\hline RCS & Pressurizer Surge Line & B-J & Volumetric \\
\hline LPI-A & Accumulator Discharge Line & B-J, C-F-1 & $\begin{array}{l}\text { Volumetric and } \\
\text { Surface }\end{array}$ \\
\hline $\mathrm{RCS}$ & Pipe Segment Between SG and RCP & B-J & Volumetric \\
\hline RCS & $\begin{array}{l}\text { Pipe Segment Between Loop Stop Valve and SG } \\
\text { (Hot Leg) }\end{array}$ & B-J & Volumetric \\
\hline RCS & $\begin{array}{l}\text { Pipe Segment Between RCP and Loop Stop Valve } \\
\text { (Cold Leg) }\end{array}$ & B-J & Volumetric \\
\hline LPI-A & Accumulator, Suction Line & C-F-1 & $\begin{array}{l}\text { Volumetric and } \\
\text { Surface }\end{array}$ \\
\hline
\end{tabular}

(a) Based on Surry-1 plant-specific system classifications. 


\subsection{Summary and Conclusions}

A method for planning inspections has been developed and has been applied in a pilot study to identify and prioritize the most risk-important systems and components at Surry-1. In the pilot application, the method used component failure probabilities estimated from the expert judgment elicitation conducted by PNL, results from PNL's Surry-1 system prioritization, and system fault trees reported in the Surry-1 PRA to prioritize to the high-priority components for inspection.

As shown in Table 3.1, contributions of component failures to core damage frequency range widely from about $1.6 \mathrm{E}-06$ to $1.6 \mathrm{E}-14$ per plant year. The cumulative risk contribution (as shown in Figure 3.5) is about 2.1E-06 per plant year. This estimate is about $5 \%$ of the total Surry-1 PRA risk. The total estimated risk is dominated by failures of the reactor pressure components (86\%). This risk is followed by the LPI system components $(10 \%)$, and then other components within the AFW and RCS (4\%). The results provide a guide to establish improved inspection priorities for nuclear power plant components.

Sensitivity analyses addressed uncertainties on parameter values and modeling assumptions. The sensitivity of component rankings to upper- and lower-bounding values of estimated rupture probabilities was established. As shown in Tables 3.1 and 3.2, the results indicated no significant changes in component rankings. Additional sensitivity analyses addressed contributions to core damage frequency due to indirect effects of component failures. The results indicate that the overall contribution to core damage frequency from the indirect effects was negligible. Sensitivity and uncertainty analyses regarding potential floodings within the plant due to pipe ruptures have not yet been addressed. Flooding from some rupture locations could disable safety-related equipment, thereby contributing significantly to core damage. This important issue will be addressed in future work.
Risk-based priorities were compared with the current Surry-1 plant-specific ASME classifications and required IS' examinations. The ASME classifications and ISI $r$ : quirements are in general qualitative agreement with 1 ssk-based rankings based on core damage frequency. The components making the greatest contributions to the core damage frequency currently have the most stringent inspection requirements. However, final conclusions for setting inspection requirements should await further pilot studies.

An approach for determining target risk and target rupture probability values has been proposed and successfully pilot tested for components within the selected systems at Surry-1. It is recognized that in some cases the estimated target values of rupture probabilities may be difficult to achieve, therefore, further studies are noeded to determine whether this approach is generally appropriate.

The analysis for the Surry-1 plant will be completed by developing the risk importance of components in the remaining systems (e.g., high-pressure injection, service water, and balance of the plant). Similar analyses will be performed for other PWRs and boiling-water reactors (BWRs), and generic trends in component importances will be established. Once the high-priority components have been identified, recommended inspection programs (method, frequency and extent) will be developed. Probabilistic structural mechanics and decision analyses will be applied to establish inspection strategies that will ensure that component failure rates are maintained at acceptable levels and in a cost-effective manner. 


\subsection{References}

ASME Research Task Force on Risk-Based Inspection Guidelines. 1991. Risk-Based Inspection-Development of Guidelines, Volume 1 General Document. CRTDVol, 20-1, American Society of Mechanical Engineers Center for Research and Technology Development.

Bertucio, R. C., and J. A. Julius. 1990. Analysis of Core Damage Frequency: Surry, Unit 1 Internal Events. NUREG/CR-4550, Sandia National Laboratories, Albuquerque, New Mexico.

Gore, B. F., T. V. Vo, and K. R. Balkey. 1991. "Status of ASME Rick-Based Inspection Guidelines Development for Nuclear Power Plants." To be presented at the 1991 ASME Winter Annual Meeting, Atlanta, Georgia.

Heinecke, C. C., V. A. Perone, M. Weaver, and C. N. Wright. 1987. Surry Units 1 and 2 Reactor Vessel Fluence and $R T_{P T S}$ Electrons. WCAP-11015, Westinghouse Electric Corporation, Pittsburgh, Pennsylvania.

Meyer, M. A., and J. M. Booker. 1989. Eliciting and Analyzing Expen Judgment. NUREG/CR-5424, Los Alamos National Laboratory, Los Alamos, New Mexico.

Russel, K. D., et al. 1987. Integrated Reliability and Risk Analysis System (IRRAS). NUREG/CR-4844, Idaho National Engineering Laboratory, Idaho Falls, Idaho.

U.S. Nuclear Regulatory Commission (NRC). 1981. Standard Review Plan 3.6.2 Determination of Rupture Locations and Dynamic Effects Associated with the Postulated Rupture of Piping. NUREG-0800, Rev. 1, U.S. Nuclear Regulatory Commission, Washington, D.C.
U.S. Nuclear Regulatory Commission (NRC). 1989. Severe Accident Risks: An Assessment for Five U.S. Nuclear Power Plants. NUREG-1150, Summary Report, Second Draft For Peer Review, U.S. Nuclear Regulatory Commission, Washington, D.C.

Vo, T. V., B. F. Gore, L. J. Eschbach, and F. A. Simonen. 1989. "Probabilistic Risk Assessment-Based Guidance for Piping Inservice Inspection." Nuclear Technology, Volume 88 (1), American Nuclear Society, La Grange Park, Illinois.

Vo, T. V., B. W. Smith, F. A. Simonen, and S. R. Doctor. 1990. "Development of Generic Inservice Inspection Guidance for Pressure Boundary Systems." Nuclear Technology, Volume 92 (3), American Nuclear Society, La Grange Park, Illinois.

Vo, T. V., P. G. Heasler, S. R. Doctor, F. A. Simonen, and B. F. Gore. 1991. "Estimate of Component Rupture Probabilities. Expert Judgment Elicitation." $\mathrm{Nu}$ clear Technology, Volume 94 (1), American Nuclear Socicty, La Grange Park, Illinois.

Whecler, T. A., S. C. Hora, W. R. Cramond, and S. D. Unwin. 1989. Analysis of Core Damage Frequency from Intermal Events: Expert Judgment Elicitation.

NUREG/CR-4550, Volume 2, Sandia National Laboratories, Albuquerque, New Mexico. 
Appendix A

Sample of Component Importance Calculations 


\section{Appendix A}

\section{Sample of Component Importance Calculations}

This appendix shows the component risk importance calculations for the reactor pressure vessel. Similar calculations were performed for the other systems (reactor coolant, low-pressure injection, and auxiliary fecdwater) that are addressed in this report. 
PROGRAM: NDE-IMPROVED ISI

SYSTEM: REACTOR PRESSURE VESSEL

COMPONENT: FLANGE TO NOZZLE/UPPER SHELL WELD

\begin{tabular}{|c|c|c|c|c|c|c|}
\hline $\begin{array}{c}\text { (1) } \\
\text { Componert } \\
\text { (location) }\end{array}$ & $\begin{array}{c}(2) \\
\text { Faliure } \\
\text { Probability }(a) \\
\text { (component size) }\end{array}$ & $\begin{array}{c}\text { (3) } \\
\text { Failure Effect }\end{array}$ & Recovery Action & $\begin{array}{l}\text { (5) } \\
\text { Core Damage } \\
\text { Frequency }\end{array}$ & $\begin{array}{c}(6) \\
\text { Importance } \\
\text { Index }\end{array}$ & $\begin{array}{c}\text { (7) } \\
\text { Renarks }\end{array}$ \\
\hline $\begin{array}{l}\text { Weld } 1 \text { - circumfer- } \\
\text { ential flange to } \\
\text { nozzle course }\end{array}$ & $\begin{array}{l}\left(157^{\prime \prime} 10\right. \\
\left.9^{*} \text { thick }\right) \\
\text { 3. } 16 E-08 \\
\text { 2. } 00 \mathrm{E}-08 \\
\text { 1. } 00 \mathrm{E}-08\end{array}$ & $\begin{array}{l}\text { Core damage was } \\
\text { assumed } \\
P_{c m / s}=1.0 \\
P_{s} / P_{f}=1.0 \\
C D P=1.0\end{array}$ & No recovery & $2.00 E-08$ & 4 & $\begin{array}{l}\text { - Low fluence and low } \\
\text { embrittlement } \\
\text { - The RPV was assumed to } \\
\text { fall given a break at this } \\
\text { location }\end{array}$ \\
\hline $\begin{array}{l}\text { Weld } 2 \text { - circumfer- } \\
\text { ential upper shell } \\
\text { to weld, intermedi- } \\
\text { ate shell }\end{array}$ & $\begin{array}{l}\left(157^{\prime \prime} 10\right. \\
9^{\prime \prime} \text { thick) } \\
\text { 1. } 0 E-07 \\
\text { 3. } 16 E-08 \\
\text { 1. } 0 E-08\end{array}$ & $\begin{array}{l}\text { Core damage was } \\
\text { assumed } \\
P_{\mathrm{cm} / \mathrm{s}}=1.0 \\
P_{s} / P_{f}=1.0 \\
C D P=1.0\end{array}$ & No recovery & $3.16 E-08$ & 3 & $\begin{array}{l}\text { - Lower fluence and lawer } \\
\text { embrittlement } \\
\text { - } \mathrm{Cu} \text { content }=0.11 \% \\
\text { Ni content }=0.7 x \text { ? }\end{array}$ \\
\hline
\end{tabular}

(a) Component fallure probability obtained from vo et al. 1991. The three values represent the median. and $35 \mathrm{X}$ and $75 \mathrm{X}$ quartiles of uncertainty distribution.

(b) Importance measure or rank relative to other components of the RPV, based on "Median Values" of failure probabilities.

(c) $\quad P_{c m}=P_{f} * \sum_{I} P_{c m / s} * P_{s i} / P_{t} * R_{i}$

(d) Based on "Median Values" of failure probabilities.

NOTE: $\quad 0$ - never used on these tables.

CDP - core damage probability given the break.

EOP - emergency operating procedure.

LOCA - loss of coolant accident.

PTS - pressurized thermal shock. 
PROGRAM: $\quad$ NDE-IMPROVED ISI

SYSTEM: REACTOR PRESSURE VESSEL

COMPONENT: LOWER SHELL/BOTTOM HEAD

\begin{tabular}{|c|c|c|c|c|c|c|}
\hline $\begin{array}{l}\text { (1) } \\
\text { Component } \\
\text { (location) }\end{array}$ & $\begin{array}{c}(2) \\
\text { Failure } \\
\text { Probability }(a) \\
\text { (component size) }\end{array}$ & $\begin{array}{l}\text { (3) } \\
\text { Failure Effect }\end{array}$ & $\begin{array}{r}\text { (4) } \\
\text { Recovery Action }\end{array}$ & $\begin{array}{l}\text { (5) } \\
\text { Core Damagg } \\
\text { Frequency }\end{array}$ & $\begin{array}{c}(6) \\
\text { Importance } \\
\text { Index }\end{array}$ & $\begin{array}{l}\text { (7) } \\
\text { Remarks } \\
\end{array}$ \\
\hline $\begin{array}{l}\text { Weld } 3 \text { - lower } \\
\text { shell }\end{array}$ & $\begin{array}{l}\left(157^{\prime \prime} 10\right. \\
9 " \text { thick }) \\
1.0 E-06 \\
3.16 E-07 \\
1.0 E-07\end{array}$ & $\begin{array}{l}\text { Core damage was } \\
\text { assumed } \\
P_{c m / s}=1.0 \\
P_{s} / P_{f}=1.0 \\
C D P=1.0\end{array}$ & No recovery & $3.16 E-07$ & 1 & $\begin{array}{l}\text { - High fluence and high } \\
\text { embrittlenent. High ther- } \\
\text { mal stress for LOCA and } \\
\text { PTSs. } \\
\text { - Critical weld based on } \\
\text { Surry PTS study (WCAP- } \\
11015 \text {. 1987). } \\
\text { - Cu content }=0.11 \% \\
\text { - Ni content }=0.7 \% \text { ? }\end{array}$ \\
\hline $\begin{array}{l}\text { Weld } 4 \text { - bottom } \\
\text { head }\end{array}$ & $\begin{array}{l}\left(157^{\prime \prime} \text { ID }\right. \\
\left.5.4^{\prime \prime} \text { thick }\right) \\
1.0 E-07 \\
3.16 E-08 \\
5.2 E-09\end{array}$ & $\begin{array}{l}\text { Core damage was } \\
\text { assumed } \\
P_{c m / s}=1.0 \\
P_{s} / P_{f}=1.0 \\
C D P=1.0\end{array}$ & No recovery & $3.16 E-08$ & 3 & $\begin{array}{l}\text { - Lower fluence and lower } \\
\text { embrittlemen. } \\
\text { - } \mathrm{Cu} \text { content }=0.11 \% \\
\text { Ni content }=0.7 \% \text { ? }\end{array}$ \\
\hline
\end{tabular}

(a) Component failure probability obtained from Vo et al. 1991. The three values represent the median. and 25\% and $75 \%$ quartiles of uncertainty distribution.

(b) Importance measure or rank relative to other components of the RPV. based on "Median Values" of failure probabilities.

(c) $\quad P_{c \text { at }}=P_{t} * \mid \sum_{i} P_{c a / s_{1}} * P_{s_{1}} / P_{t} * R_{i}$

(d) Based on "Median Values" of failure probabilities.

NOTE: $\quad 0$ - never used on these tables.

CDP - core damage probability given the break.

EOP - emergency operating procedure.

LOCA - loss of coolant accident.

PTS - pressurized thermal shock. 
PROGRAM: NDE-IMPROVED ISI

SYSTEM: REACTOR PRESSURE VESSEL

COMPONENT: BOTTOM HEAD/INTERMEDIATE SHELL

\begin{tabular}{|c|c|c|c|c|c|c|}
\hline $\begin{array}{c}\text { (1) } \\
\text { Component } \\
\text { (location) } \\
\end{array}$ & $\begin{array}{c}\text { (2) } \\
\text { Failurz } \\
\text { Probability }(a) \\
\text { (component size) }\end{array}$ & $\begin{array}{c}\text { (3) } \\
\text { Failure Effect }\end{array}$ & $\begin{array}{c}\text { (4) } \\
\text { Recovery Action }\end{array}$ & $\begin{array}{l}\text { (5) } \\
\text { Core Damage } \\
\text { Frequency }\end{array}$ & $\begin{array}{c}(6) \\
\text { Importapce } \\
\text { Index }\end{array}$ & $\begin{array}{l}\text { (7) } \\
\text { Remarks }\end{array}$ \\
\hline $\begin{array}{l}\text { Weld } 5 \text { - bottom } \\
\text { head }\end{array}$ & $\begin{array}{l}\left(157^{\prime \prime} \text { ID }\right. \\
5.4^{\prime \prime} \text { thick) } \\
\text { 1.E-07 } \\
3.16 E-08 \\
5.2 E-09\end{array}$ & $\begin{array}{l}\text { Core damage was } \\
\text { assumed } \\
P_{c m / s}=1.0 \\
P_{s} / P_{f}=1.0 \\
C D P=1.0\end{array}$ & No recovery & $3.16 E-08$ & 3 & $\begin{array}{l}\text { Low fluence and low } \\
\text { thermal stress. }\end{array}$ \\
\hline $\begin{array}{l}\text { Weld } 6 \text { - longitudi- } \\
\text { nal weld intermedi- } \\
\text { ate shell }\end{array}$ & $\begin{array}{l}(100 " \text { length }) \\
5 E-07 \\
3.16 E-07 \\
1.1 E-07\end{array}$ & $\begin{array}{l}\text { Core damage was } \\
\text { assumed } \\
P_{c m / s}=1.0 \\
P_{s} / P_{f}=1.0 \\
C D P=1.0\end{array}$ & No recovery & $3.16 E-07$ & 1 & $\begin{array}{l}\text { - High fluence and embrit- } \\
\text { tlement at lower end of } \\
\text { this weld. High thermal } \\
\text { stress for LOCA and PTS. } \\
\text { - Cu content }=0.11 \% \\
\text { - } N \text { i content }=0.7 \% \text { ? }\end{array}$ \\
\hline
\end{tabular}

a) Component failure probability obtained from Vo et al. 1991. The three values represent the median, and $25 \%$ and $75 \%$ quartiles of uncertaintu distribution.

作

(b) Importance measure or rank relative
(c) $P_{c m}=P_{t} * \sum_{c m / s_{1}} * P_{s_{1}} / P_{t} * R_{t \mid}$

(d) Based on "Median Values" of failure probabilities.

NOTE: $\quad 0$ - never used on these tables.

CDP - core damage probability given the break.

EOP - emergency operating procedure.

LOCA - loss of coolant accident.

PTS - pressurized thermal shock. 


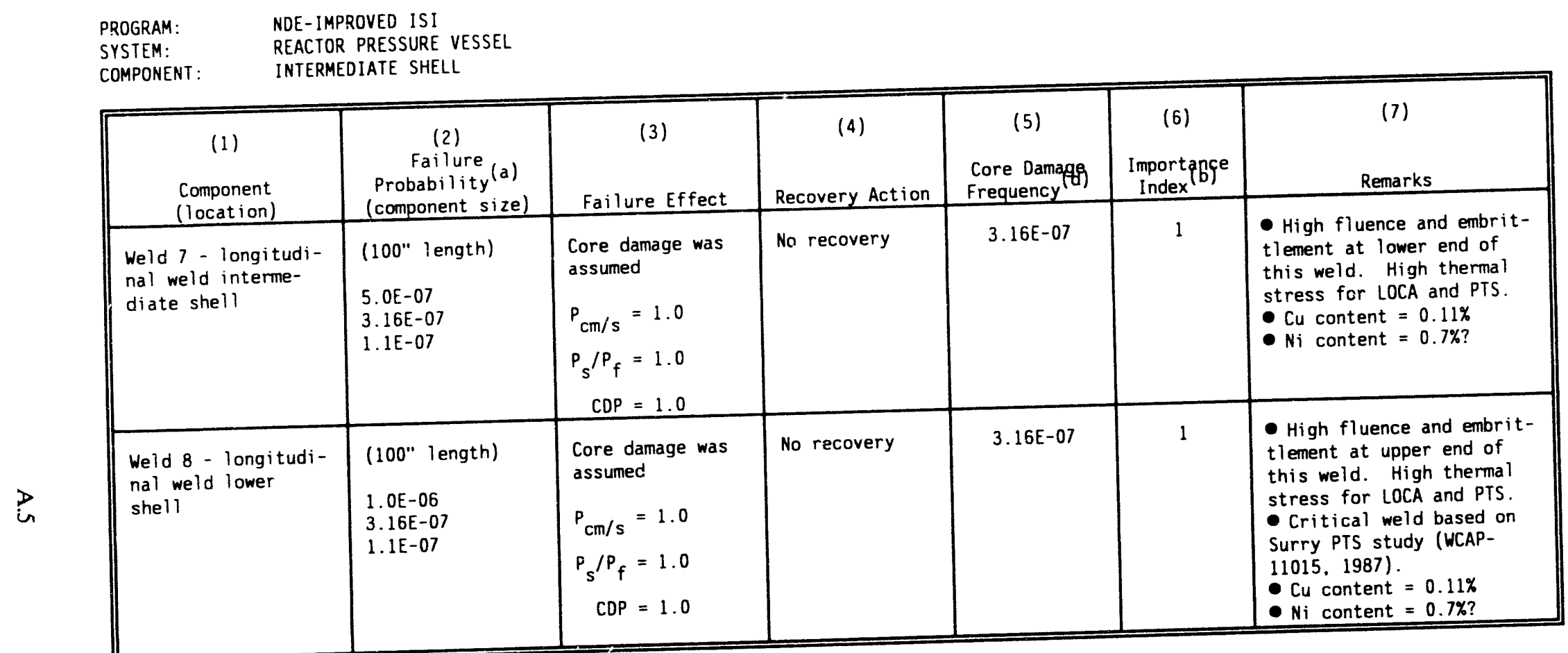

作

(a) Component failure probability of

(b) of uncertainty distribution.

(c) $\quad P_{c m}=P_{t} * \sum_{I} P_{c m / s} * P_{s_{1}} / P_{t} * R_{t}$

(d) Based on "Median Values" of failure probabilities.

NOTE: $\quad Q$ - never used on these tables.

QD - core damage probability given the break.

EOP - emergency operating procedure.

LOCA - loss of coolant accident.

PTS - pressurized thermal shock. 
PROGRAM: $\quad$ NDE-IMPROVED ISI

SYSTEM: REACTOR PRESSURE VESSEL

COMPONENT: INTERMEDIATE SHELL/NOZZLE TO VESSEL WELD

\begin{tabular}{|c|c|c|c|c|c|c|}
\hline $\begin{array}{c}\text { (1) } \\
\text { Component } \\
\text { (location) }\end{array}$ & $\begin{array}{c}(2) \\
\text { Failure } \\
\text { Probability }(a) \\
\text { (component size) }\end{array}$ & Failure Effect & Recovery Action & $\begin{array}{l}\text { (5) } \\
\text { Core Damage } \\
\text { Frequency }\end{array}$ & $\begin{array}{c}(6) \\
\text { Importange } \\
\text { Index }\end{array}$ & $\begin{array}{c}\text { (7) } \\
\text { Remarks }\end{array}$ \\
\hline $\begin{array}{l}\text { Weld } 9 \text { - longitudi- } \\
\text { nal weld lower } \\
\text { shell }\end{array}$ & $\begin{array}{l}(100 " \text { length }) \\
1.0 E-06 \\
3.16 E-07 \\
1.1 E-07\end{array}$ & $\begin{array}{l}\text { Core damage was } \\
\text { assumed } \\
P_{\mathrm{cm} / \mathrm{s}}=1.0 \\
P_{s} / P_{f}=1.0 \\
C D P=1.0\end{array}$ & No recovery & $3.16 E-07$ & 1 & $\begin{array}{l}\text { - High fluence and embrit- } \\
\text { tlement at upper end of } \\
\text { this weld. High thermal } \\
\text { stress for LOCA and PTS. } \\
\text { Critical weld based on } \\
\text { Surry PTS study (WCAP- } \\
11015 \text {, 1987). } \\
\text { Cu content }=0.11 \% \\
\text { Ni content }=0.7 \% \text { ? }\end{array}$ \\
\hline $\begin{array}{l}\text { Weld } 10 \text { - nozzle- } \\
\text { to-vessel weld. } \\
\text { Loop } 1 \text { outlet }\end{array}$ & $\begin{array}{l}\text { (app. } 40 " \text { dia.) } \\
3.16 E-08 \\
2.0 E-08 \\
1.1 E-08\end{array}$ & $\begin{array}{l}\text { L/LOCA (see re- } \\
\text { mark) } \\
P_{\mathrm{cm} / \mathrm{s}}=5.00 \mathrm{E}-04 \\
P_{\mathrm{s}} / P_{\mathrm{f}}=1.0 \\
\quad C D P=5.00 \mathrm{E}-04\end{array}$ & Follow EOPs & $1.00 \mathrm{E}-11$ & 7 & $\begin{array}{l}\text { - Lower fluence and low } \\
\text { embrittlement. } \\
\text { - Break at this location } \\
\text { was assumed to be equiva- } \\
\text { lent to a large LOCA. }\end{array}$ \\
\hline
\end{tabular}

(a) Component failure probability obtained from Vo et al. 1991 . The three values represent the median. and $25 \%$ and $75 \%$ quartiles of uncertainty distribution.

Importance measure or rank relative to other components of the RPV, based on "Median Values" of failure probabilities.

(c) $\quad P_{c m}=P_{f} * \sum_{i} P_{c m / s_{i}} * P_{s_{i}} / P_{t} * R_{i}$

(d) Based on "Median Values" of failure probabilities.

NOTE: $\quad Q$ - never used on these tables.

CDP - core damage probability given the break.

EOP - emergency operating procedure.

LOCA - loss of coolant accident.

PTS - pressurized thermal shock. 


\begin{tabular}{|c|c|c|c|c|c|c|}
\hline $\begin{array}{l}\text { PROGRAM: } \\
\text { SYSTEM: } \\
\text { COMPONENT: }\end{array}$ & $\begin{array}{l}\text { ROVED ISI } \\
\text { PRESSURE VESSEL } \\
\text { TO VESSEL WELDS }\end{array}$ & & & & & \\
\hline $\begin{array}{c}\text { (1) } \\
\text { Component } \\
\text { (location) } \\
\end{array}$ & $\begin{array}{c}\text { (2) } \\
\text { Failure } \\
\text { Probability }(a) \\
\text { (component size) } \\
\end{array}$ & $\begin{array}{c}\text { (3) } \\
\text { Failure Effect }\end{array}$ & $\begin{array}{r}\text { (4) } \\
\text { Recovery Action }\end{array}$ & $\begin{array}{l}\text { (5) } \\
\text { Core Damage } \\
\text { Frequency }\end{array}$ & $\begin{array}{c}(6) \\
\text { Importance } \\
\text { Index }\end{array}$ & $\begin{array}{r}\text { (7) } \\
\text { Remarks } \\
\end{array}$ \\
\hline $\begin{array}{l}\text { Weld } 11 \text { - nozzle- } \\
\text { to-vessel weld. } \\
\text { Loop } 1 \text { inlet }\end{array}$ & $\begin{array}{l}\text { (app. 40" dia.) } \\
3.16 E-08 \\
2.0 E-08 \\
1.0 E-08\end{array}$ & $\begin{array}{l}\text { L/LOCA was } \\
\text { assumed given a } \\
\text { break } \\
P_{\mathrm{cm} / \mathrm{s}}=5.00 \mathrm{E}-04 \\
\mathrm{P}_{\mathrm{s}} / \mathrm{P}_{\mathrm{f}}=1.0 \\
\mathrm{CDP}=5.00 \mathrm{E}-04\end{array}$ & No recovery & $1.00 E-11$ & 10 & $\begin{array}{l}\text { - Lower fluence and low } \\
\text { embrittlement. }\end{array}$ \\
\hline $\begin{array}{l}\text { Weld } 12 \text { - nozzle- } \\
\text { to-vessel welds. } \\
\text { Loop } 2 \text { outlet }\end{array}$ & $\begin{array}{l}\text { (app. } 40 " \text { dia.) } \\
3.16 E-08 \\
2.0 E-08 \\
1.0 E-08\end{array}$ & $\begin{array}{l}\text { L/LOCA was as- } \\
\text { sumed given a } \\
\text { break } \\
P_{c \mathrm{~cm} / \mathrm{s}}=5.00 \mathrm{E}-04 \\
P_{\mathrm{s}} / \mathrm{P}_{\mathrm{f}}=1.0 \\
\mathrm{CDP}=5.00 \mathrm{E}-04\end{array}$ & Follow EOPs & $1.00 E-11$ & 10 & $\begin{array}{l}\text { - Lower fluence and low } \\
\text { embrittlement. }\end{array}$ \\
\hline
\end{tabular}

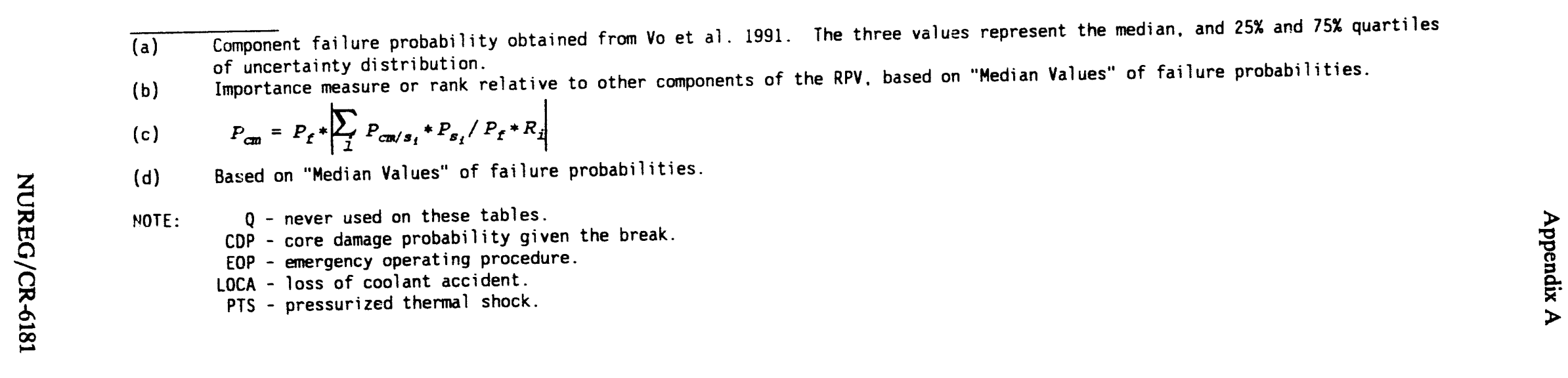


PROGRAM: NDE-IMPROVED ISI

SYSTEM: $\quad$ REACTOR PRESSURE VESSEL

COMPONENT: NOZZLE TO VESSEL WELDS

\begin{tabular}{|c|c|c|c|c|c|c|}
\hline $\begin{array}{c}\text { (1) } \\
\text { Component } \\
\text { (location) } \\
\end{array}$ & $\begin{array}{c}\text { (2) } \\
\text { Failure } \\
\text { Probability } \\
\text { (component size) } \\
\end{array}$ & $\begin{array}{c}\text { (3) } \\
\text { Failure Effect }\end{array}$ & $\begin{array}{c}\text { (4) } \\
\text { Recovery Action }\end{array}$ & $\begin{array}{l}\text { (5) } \\
\text { Core Damaqg } \\
\text { Frequency }\end{array}$ & $\begin{array}{c}(6) \\
\text { Importance } \\
\text { Index }\end{array}$ & $\begin{array}{r}\text { (7) } \\
\text { Remarks } \\
\end{array}$ \\
\hline $\begin{array}{l}\text { Weid } 13 \text { - nozzle- } \\
\text { to-vessel weld. } \\
\text { Loop } 2 \text { inlet }\end{array}$ & $\begin{array}{l}\text { (app. 40" dia.) } \\
3.16 E-08 \\
2.0 E-08 \\
1.0 E-08\end{array}$ & $\begin{array}{l}\text { L/LOCA was } \\
\text { assumed given a } \\
\text { break } \\
\mathrm{P}_{\mathrm{cm} / \mathrm{s}}=5.00 \mathrm{E}-04 \\
\mathrm{P}_{\mathrm{s}} / \mathrm{P}_{\mathrm{f}}=1.0 \\
C D P=5.00 \mathrm{E}-04\end{array}$ & Follow EOPS & $1.00 E-11$ & 10 & $\begin{array}{l}\text { - Lower fluence and low } \\
\text { embrittlement. }\end{array}$ \\
\hline $\begin{array}{l}\text { Weld } 14 \text { - nozzle- } \\
\text { to-vessel welds. } \\
\text { Loop } 3 \text { outlet }\end{array}$ & $\begin{array}{l}\text { (app. 40" dia.) } \\
3.16 E-08 \\
2.0 E-08 \\
1.0 E-08\end{array}$ & $\begin{array}{l}\text { L/LOCA was as- } \\
\text { sumed given a } \\
\text { break } \\
P_{C \mathrm{Cm} / \mathrm{s}}=5.00 \mathrm{E}-04 \\
P_{s} / P_{f}=1.0 \\
C D P=5.00 E-04\end{array}$ & Follow EOPs & $1.00 E-11$ & 10 & $\begin{array}{l}\text { - Lower fluence and low } \\
\text { embrittlement. }\end{array}$ \\
\hline
\end{tabular}

(a) Component failure probability obtained from Vo et aì. 1991 . The three values represent the median. and $25 \%$ and $75 \%$ quartiles (b) uncertainty distribution.

(c) $\quad P_{c m}=P_{f} *\left|\sum_{1} P_{c m / s_{i}} * P_{s_{i}} / P_{t} * R_{i}\right|$

(d) Based on "Median Values" of failure probabilities.

NOTE: $\quad Q$ - never used on these tables.

CDP - core damage probability given the break.

EOP - emergency operating procedure.

LOCA - loss of coolant accident.

PTS - pressurized thermal shock. 
PROGRAM: NDE-IMPROVED ISI

SYSTEM: $\quad$ REACTOR PRESSURE VESSEL

COMPONENT: NOZZLE TO VESSEL WELD/NOZZLE FORGINGS

\begin{tabular}{|c|c|c|c|c|c|c|}
\hline $\begin{array}{c}\text { (1) } \\
\text { Component } \\
\text { (location) } \\
\end{array}$ & $\begin{array}{c}(2) \\
\text { Failure } \\
\text { Probability }(a) \\
\text { (component size) }\end{array}$ & Failure Effect & $\begin{array}{r}\text { (4) } \\
\text { Recovery Action } \\
\end{array}$ & $\begin{array}{l}\text { (5) } \\
\text { Core Damaqf } \\
\text { Frequency }\end{array}$ & $\begin{array}{c}(6) \\
\text { Importange } \\
\text { Index }\end{array}$ & $\begin{array}{c}\text { (7) } \\
\text { Remarks } \\
\end{array}$ \\
\hline $\begin{array}{l}\text { Weid } 15 \text { - nozzle- } \\
\text { to-vessel weld. } \\
\text { Loop } 3 \text { inlet }\end{array}$ & $\begin{array}{l}\text { (app. } 40 " \text { dia.) } \\
3.16 E-08 \\
2.0 E-08 \\
1.0 E-08\end{array}$ & $\begin{array}{l}\text { L/LOCA was } \\
\text { assumed given a } \\
\text { break } \\
P_{\mathrm{cm} / \mathrm{s}}=5.00 \mathrm{E}-04 \\
P_{\mathrm{s}} / P_{f}=1.0 \\
C D P=5.00 \mathrm{E}-04\end{array}$ & Follow EOPs & $1.00 E-11$ & 10 & $\begin{array}{l}\text { - Lower fluence and low } \\
\text { embrittlement. }\end{array}$ \\
\hline $\begin{array}{l}\text { Nozzle Forgings - } \\
\text { inlets for Loops } 1 \text {. } \\
\text { 2. and } 3\end{array}$ & $\begin{array}{l}\text { (app. 40" dia.) } \\
5.0 E-08 \\
3.0 E-08 \\
1.0 E-08\end{array}$ & $\begin{array}{l}\text { L/LOCA was as- } \\
\text { sumed given a } \\
\text { break } \\
P_{\mathrm{cm} / \mathrm{s}}=5.00 \mathrm{E}-04 \\
P_{\mathrm{s}} / P_{\mathrm{f}}=1.0 \\
\mathrm{CDP}=5.00 \mathrm{E}-04\end{array}$ & Follow EOPs & $1.50 E-11$ & 10 & $\begin{array}{l}\text { - High stress at nozzle } \\
\text { corner. Potential for } \\
\text { high thermal stress from } \\
\text { cold fluid injection. }\end{array}$ \\
\hline
\end{tabular}

(a) Component failure probability obtained from Vo et al. 1991. The three values represent the median, and $25 \%$ and $75 \%$ quartiles of uncertainty distribution.

(b) Importance measure or rank relative to other components of the RPV, based on "Median Values" of failure probabilities

(c) $\quad P_{c m}=P_{f} * \mid \sum_{i} P_{c m / s_{i}} * P_{s_{i}} / P_{t} * R_{i}$

(d) Based on "Median Values" of failure probabilities.

NOTE: $\quad Q$ - never used on these tables.

CDP - core damage probability given the break.

EOP - emergency operating procedure.

LOCA - loss of coolant accident.

PTS - pressurized thermal shock. 
PROGRAM: $\quad$ NDE-IMPROVED ISI

SYSTEM: $\quad$ REACTOR PRESSURE VESSEL

COMPONENT: NOZZLE FORGINGS/BELTLINE PLATE

\begin{tabular}{|c|c|c|c|c|c|c|}
\hline $\begin{array}{c}\text { (1) } \\
\text { Component } \\
\text { (location) }\end{array}$ & $\begin{array}{c}\text { (2) } \\
\text { Failure }(a) \\
\text { Probability } \\
\text { (component size) }\end{array}$ & $\begin{array}{c}\text { (3) } \\
\text { Failure Effect }\end{array}$ & $\begin{array}{r}\text { (4) } \\
\text { Recovery Action }\end{array}$ & $\begin{array}{l}\text { (5) } \\
\text { Core Damage } \\
\text { Frequency }\end{array}$ & $\begin{array}{c}(6) \\
\text { Importange } \\
\text { Index }\end{array}$ & $\begin{array}{r}\text { (7) } \\
\text { Remarks } \\
\end{array}$ \\
\hline $\begin{array}{l}\text { Nozzle Forgings - } \\
\text { outlets for Loops } \\
\text { 1.2. and } 3\end{array}$ & $\begin{array}{l}\text { (app. 40" dia.) } \\
5.0 E-08 \\
2.0 E-08 \\
1.0 E-08\end{array}$ & $\begin{array}{l}\text { L/LOCA was } \\
\text { assumed given a } \\
\text { break } \\
P_{\mathrm{Cm} / \mathrm{s}}=5.00 \mathrm{E}-04 \\
\mathrm{P}_{\mathrm{s}} / \mathrm{P}_{\mathrm{f}}=1.0 \\
\mathrm{CDP}=5.00 \mathrm{E}-04\end{array}$ & Follow EOPs & $1.00 E-11$ & 10 & $\begin{array}{l}\text { - High stress at nozzle } \\
\text { corner. }\end{array}$ \\
\hline $\begin{array}{l}\text { Beltline Plate } \\
\text { (base metal) }\end{array}$ & $\begin{array}{l}(157 " 1 D \\
9 " \text { thick) } \\
1.0 E-07 \\
1.0 E-07 \\
8.0 E-J Z\end{array}$ & $\begin{array}{l}\text { Core damage was } \\
\text { assumed } \\
P_{c m / s}=1.0 \\
P_{s} / P_{f}=1.0 \\
C D P=1.0\end{array}$ & No recovery & $1.00 E-07$ & 2 & $\begin{array}{l}\text { - High fluence, but lower } \\
\text { embrittlement rate than } \\
\text { welds. }\end{array}$ \\
\hline
\end{tabular}

(a) Component failure probability obtained from Vo et al. 1991. The three values represent the median, and $25 \%$ and $75 \%$ quartiles of uncertainty distribution.

(b) Importance measure or rank relative to other components of the RPV. based on "Median Values" of failure probabilities.

(c) $\quad P_{\mathrm{cm}}=P_{f} * \sum_{I} P_{\mathrm{cm} / \mathrm{s}_{i}} * P_{\mathrm{s}_{i}} / P_{t} * R_{\mathrm{i}}$

(d) Based on "Median Values" of failure probabilities.

NOTE: $\quad Q$ - never used on these tables.

CDP - core damage probability given the break.

EOP - emergency operating procedure.

LOCA - loss of coolant accident.

PTS - pressurized thermal shock. 


\begin{tabular}{|c|c|c|c|c|c|c|}
\hline $\begin{array}{l}\text { PROGRAM: } \\
\text { SYSTEM: } \\
\text { COMPONENT: }\end{array}$ & $\begin{array}{l}\text { MPROVED ISI } \\
\text { OR PRESSURE VESSEL } \\
\text { LL SHELL/UPPER HEAD }\end{array}$ & & & & & \\
\hline $\begin{array}{c}\text { (1) } \\
\text { Component } \\
\text { (location) } \\
\end{array}$ & $\begin{array}{c}\text { (2) } \\
\text { Failure } \\
\text { Probability (a) } \\
\text { (component size) }\end{array}$ & $\begin{array}{l}\text { (3) } \\
\text { Failure Effect }\end{array}$ & $\begin{array}{r}\text { (4) } \\
\text { Recovery Action }\end{array}$ & $\begin{array}{l}\text { (5) } \\
\text { Core Damagg } \\
\text { Frequency }\end{array}$ & $\begin{array}{c}(6) \\
\text { Importance } \\
\text { Index }\end{array}$ & $\begin{array}{r}\text { (7) } \\
\text { Remarks } \\
\end{array}$ \\
\hline $\begin{array}{l}\text { Vessel Shell } \\
\text { outside beltline } \\
\text { (base metal) }\end{array}$ & $\begin{array}{l}(157 " 00 \\
9 " \text { thick }) \\
3.16 E-08 \\
1.0 E-08 \\
1.0 E-08\end{array}$ & $\begin{array}{l}\text { Core damage was as- } \\
\text { sumed given a break at } \\
\text { this location } \\
\mathrm{P}_{\mathrm{cm} / \mathrm{s}}=1.0 \\
\mathrm{P}_{\mathrm{s}} / \mathrm{P}_{\mathrm{f}}=1.0 \\
\mathrm{COP}=1.0\end{array}$ & No recovery & $1.00 \mathrm{E}-08$ & 5 & $\begin{array}{l}\text { - Lower fluence and less } \\
\text { embrittlement. }\end{array}$ \\
\hline $\begin{array}{l}\text { Upper Head (base } \\
\text { metal) }\end{array}$ & $\begin{array}{l}\text { (157" ID } \\
6 " \text { thick) } \\
5.0 E-08 \\
3.6 E-08 \\
1.0 E-08\end{array}$ & $\begin{array}{l}\text { L/LOCA was assumed } \\
\text { given a break at this } \\
\text { location } \\
P_{\mathrm{Cm} / \mathrm{s}}=5.00 \mathrm{E}-04 \\
P_{\mathrm{S}} / P_{\mathrm{f}}=1.0 \\
\mathrm{CDP}=5.00 \mathrm{E}-04\end{array}$ & No recovery & $1.58 \mathrm{E}-11$ & 9 & $\begin{array}{l}\text { - Low fluence and low } \\
\text { embrittlement. }\end{array}$ \\
\hline
\end{tabular}

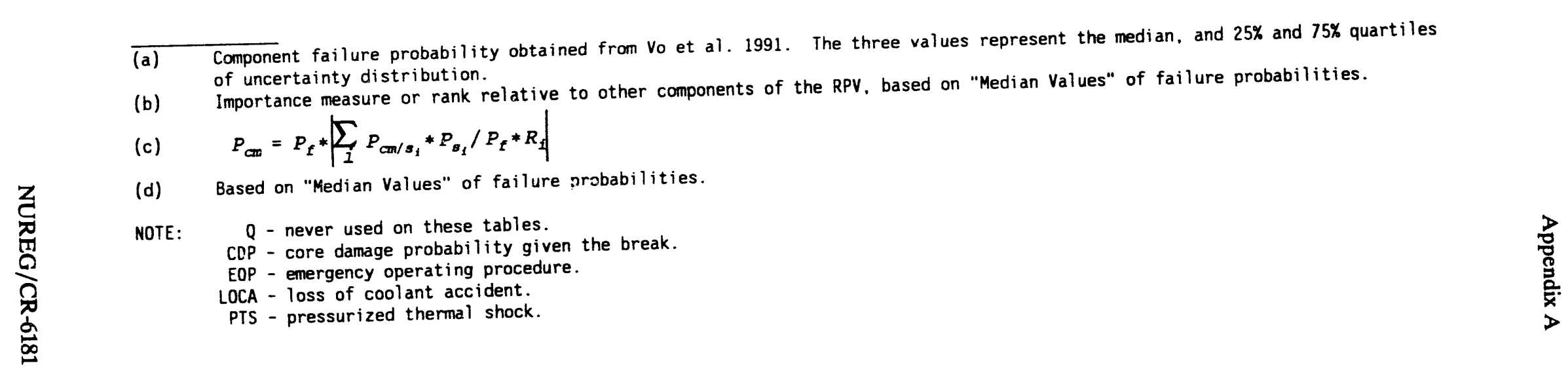


PROGRAM: NDE-IMPROVED ISI

SYSTEM: REACTOR PRESSURE VESSEL

COMPONENT: LOWER HEAD/VESSEL FLANGE

\begin{tabular}{|c|c|c|c|c|c|c|}
\hline $\begin{array}{c}\text { (1) } \\
\text { Component } \\
\text { (location) } \\
\end{array}$ & $\begin{array}{c}\text { (2) } \\
\text { Failure }(a) \\
\text { Probability } \\
\text { (component size) } \\
\end{array}$ & Failure Effect & $\begin{array}{r}\text { (4) } \\
\text { Recovery Action }\end{array}$ & $\begin{array}{l}\text { (5) } \\
\text { Core Damaqg } \\
\text { Frequency }\end{array}$ & $\begin{array}{c}(6) \\
\text { Importance } \\
\text { Index }\end{array}$ & (7) \\
\hline $\begin{array}{l}\text { Lower Head (base } \\
\text { metal) }\end{array}$ & $\begin{array}{l}\left(157^{\prime \prime} 00\right. \\
5.4^{\prime \prime} \text { thick) } \\
5.0 E-08 \\
1.0 E-08 \\
1.0 E-08\end{array}$ & $\begin{array}{l}\text { Core damage was } \\
\text { assumed } \\
P_{\mathrm{cm} / \mathrm{s}}=1.0 \\
P_{s} / P_{f}=1.0 \\
C D P=1.0\end{array}$ & No recovery & $1.00 E-08$ & 5 & $\begin{array}{l}\text { - Lower fluence and low } \\
\text { embrittlement. }\end{array}$ \\
\hline Vessel Flange & $\begin{array}{l}\left(149^{\prime \prime} 10 \times 184^{\prime \prime}\right. \\
O D) \\
5.0 E-08 \\
8.0 E-08 \\
1.0 E-08\end{array}$ & $\begin{array}{l}\text { L/LOCA was as- } \\
\text { sumed given the } \\
\text { break } \\
P_{C \mathrm{Cm} / \mathrm{s}}=5.00 \mathrm{E}-04 \\
P_{\mathrm{s}} / P_{f}=1.0 \\
C D P=5.00 \mathrm{E}-04\end{array}$ & No recovery & $1.00 \mathrm{E}-11$ & 10 & $\begin{array}{l}\text { - Low fluence. Stress } \\
\text { concentration from closure } \\
\text { studs. } \\
\text { - Potential surface imper- } \\
\text { fection. However. it has } \\
\text { been eliminated: there- } \\
\text { fore. creating more reli- } \\
\text { able flange surface. }\end{array}$ \\
\hline
\end{tabular}
Component failure probability obtained from vo et al. 1991. The three values represent the median. and $25 \%$ and $75 \%$ quartiles of uncertainty distribution.

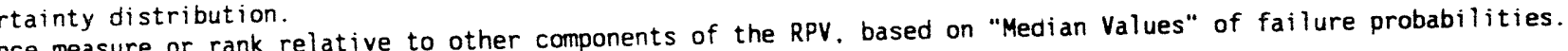

(b) $P_{\mathrm{cm}}=P_{f} * \sum_{i} P_{\mathrm{cm} / \mathrm{s}_{1}} * P_{s} / P_{t} * R_{\mathrm{d}}$

(d) Based on "Median Values" of failure probabilities.

NOTE: $\quad Q$ - never used on these tables.

CDP - core damage probability given the break.

EOP - emergency operating procedure.

LOCA - loss of coolant accident.

PTS - pressurized thermal shock. 
PROGRAM: $\quad$ NDE-IMPROVED ISI

SYSTEM: REACTOR PRESSURE VESSEL

COMPONENT: VESSEL FLANGE/STUDS

\begin{tabular}{|c|c|c|c|c|c|c|}
\hline $\begin{array}{c}\text { (1) } \\
\text { Component } \\
\text { (location) } \\
\end{array}$ & $\begin{array}{c}\text { (2) } \\
\text { Failure } \\
\text { Probability } \\
\text { (component size) }\end{array}$ & Failure Effect & Recovery Action & $\begin{array}{l}\text { (5) } \\
\text { Core Damage } \\
\text { Frequency }\end{array}$ & $\begin{array}{c}(6) \\
\text { Importance } \\
\text { Index }\end{array}$ & $\begin{array}{r}\text { (7) } \\
\text { Remarks } \\
\end{array}$ \\
\hline $\begin{array}{l}\text { Closure Head } \\
\text { Flange }\end{array}$ & $\begin{array}{l}\left(149^{\prime \prime} 10 \times 184^{\prime \prime}\right. \\
\text { OD) } \\
5.0 E-08 \\
2.0 E-08 \\
1.0 E-08\end{array}$ & $\begin{array}{l}\text { L/LOCA was as- } \\
\text { sumed given a } \\
\text { break at this } \\
\text { location } \\
P_{C \mathrm{Cm} / \mathrm{s}}=5.00 \mathrm{E}-04 \\
\mathrm{P}_{\mathrm{S}} / \mathrm{P}_{\mathrm{f}}=1.0 \\
\mathrm{CDP}=5.00 \mathrm{E}-04\end{array}$ & No recovery & $1.00 E-11$ & 10 & $\begin{array}{l}\text { - Low fluence. Stress concen- } \\
\text { tration from closure studs. } \\
\text { - Potent ial leakage at RPV } \\
\text { flanged leak off line (1" } \\
\text { line) due to } 0 \text {-ring or valves } \\
\text { (upstream) leakage. }\end{array}$ \\
\hline $\begin{array}{l}\text { Reactor Vessel } \\
\text { Studs ( } 58 \text { studs) }\end{array}$ & $\begin{array}{l}\text { (app. 6" dia. } \\
\text { each) } \\
1.0 E-06 \\
1.0 E-07 \\
3.16 E-08\end{array}$ & $\begin{array}{l}\text { L/LOCA was as- } \\
\text { sumed given the } \\
\text { break (see re- } \\
\text { marks) } \\
P_{\mathrm{cm} / \mathrm{s}}=5.00 \mathrm{E}-04 \\
\mathrm{P}_{\mathrm{s}} / \mathrm{P}_{\mathrm{f}}=1.0 \\
\mathrm{CDP}=5.00 \mathrm{E}-04\end{array}$ & No recovery & $5.00 E-11$ & 8 & $\begin{array}{l}\text { - Multiple failure of vessel } \\
\text { studs must be postulated for } \\
\text { LOCA. } \\
\text { - Some stud nicks and gauge } \\
\text { problems. } \\
\text { - Multiple stud failures con- } \\
\text { tribute a small fraction of } \\
\text { core damage frequency (e.g.. } \\
\text { Chi-square distribution to } \\
\text { quantify contributions from } \\
\text { multiple stud failures). }\end{array}$ \\
\hline
\end{tabular}

(a) Component failure probability obtained from Vo et al. 1991. The three values represent the median, and $25 \%$ and $75 \%$ quartiles of uncertainty distribution.

(b) Importance measure or rank relative to other components of the RPV, based on "Median Values" of failure probabilities.

(c) $\quad P_{c \mathrm{~m}}=P_{t} * \mid \sum_{i} P_{c \mathrm{~cm} / s_{i}} * P_{s_{i}} / P_{t} * R_{i}$

(d) Based on "Median Values" of failure probabilities.

NOTE: $\quad 0$ - never used on these tables.

COP - core damage probability given the break.

EOP - emergercy operating procedure.

LOCA - loss of coolant accident.

PTS - pressurized thermal shock. 
PROGRAM: NDE-IMPROVED ISI

SYSTEM: $\quad$ REACTOR PRESSURE VESSEL

COMPONENT: CRDNS/INSTRUMENT LINES

\begin{tabular}{|c|c|c|c|c|c|c|}
\hline $\begin{array}{c}\text { (1) } \\
\text { Component } \\
\text { (location) }\end{array}$ & $\begin{array}{c}(2) \\
\text { Failure } \\
\text { Probability }(a) \\
\text { (component size) }\end{array}$ & Failure Effect & Recovery Action & $\begin{array}{l}\text { (5) } \\
\text { Core Damage } \\
\text { Frequency }\end{array}$ & $\begin{array}{c}(6) \\
\text { Importapce } \\
\text { Index }\end{array}$ & $\begin{array}{c}\text { (7) } \\
\text { Remarks } \\
\end{array}$ \\
\hline $\begin{array}{l}\text { Control Rod Drive } \\
\text { Mechanism ( } \approx 55 \\
\text { penetrations of } \\
\text { upper head) }\end{array}$ & $\begin{array}{l}\text { (app. 4" dia.) } \\
5.48 E-05 \\
1.0 E-05 \\
4.47 E-06\end{array}$ & $\begin{array}{l}\text { L/LOCA was as- } \\
\text { sumed given a } \\
\text { break at (see } \\
\text { remarks) } \\
P_{\mathrm{Cm} / \mathrm{s}}=5.00 \mathrm{E}-04 \\
P_{\mathrm{s}} / P_{\mathrm{f}}=1.0 \\
C D P=5.00 \mathrm{E}-04\end{array}$ & No recovery & $5.00 E-09$ & 6 & $\begin{array}{l}\text { - Contribution from multiple } \\
\text { CRDM failures were insignifi- } \\
\text { cant (e.g... using Chi-square } \\
\text { distribution to estimate the } \\
\text { failure effect due to multiple } \\
\text { CRDM failures). }\end{array}$ \\
\hline $\begin{array}{l}\text { Instrument line } \\
\text { Penetrations } \\
\text { (lower head. } 100 \\
\text { instrument lines) }\end{array}$ & $\begin{array}{l}\text { (app. 1" dia.) } \\
\text { 8.37E-05 } \\
1.0 E-05 \\
3.16 E-06\end{array}$ & $\begin{array}{l}\text { L/LOCA was as- } \\
\text { sumed } \\
P_{\mathrm{Cm} / \mathrm{s}}=5.00 \mathrm{E}-04 \\
P_{s} / P_{f}=1.0 \\
C D P=5.00 E-04\end{array}$ & No recovery & $5.00 E-09$ & 6 & $\begin{array}{l}\text { - Cracking and repairs have } \\
\text { been reported at some plants. } \\
\text { - Seal table (thimble tube) } \\
\text { leakage due to seal fitting } \\
\text { failures or out of adjustment. } \\
\text { - Contribution to CDP from } \\
\text { multiple IL failures was esti- } \\
\text { mated to be insignificant. }\end{array}$ \\
\hline Lower Head Skirt & -- & -- & -- & - & -- & - Laying on concrete support. \\
\hline
\end{tabular}

(a) Component failure probability obtained from Vo et al. 1991. The three values represent the median. and $25 \%$ and $75 x$ quartiles of uncertainty distribution.

(b) Importance measure or rank relative to other components of the RPV. based on "Median Values" of failure probabilities.

(c) $\quad P_{c m}=P_{f} * \mid \sum_{I} P_{c a / s i} * P_{s i} / P_{t} * R_{i}$

(d) Based on "Median Values" of failure probabilities.

NOTE: $\quad Q$ - never used on these tables.

COP - core damage probability given the break.

EOP - emergency operating procedure.

LOCA - loss of coolant accident.

PTS - pressurized thermal shock. 


\section{DISTRIBUTION}

No. of

Copies

\section{OFFSITE}

2 A. J. Hiser, Jr. NRC/RES

Mail Stop NS $217 \mathrm{C}$

M. R. Hum

NRC/NRR

Mail Stop 7 D4

G. Johnson

NRC/RES

Mail Stop 7 D4

J. Muscara

NRC/RES

Mail Stop NS $217 \mathrm{C}$

D. W. Craig

NRC/RES

Mail Stop NS 217C

J. Strosnider

NRC/NRR

Mail Stop 7 D4

J. P. Durr

NRC/Region I

M. C. Modes

NRC/Region I

A. R. Herdt

NRC/Region II

J. J. Blake

NRC/Region II

J. Jacobson

NRC/Region III
No. of

Copies

\section{FOREIGN}

J. R. Tomlinson

NDT Application Centre

Nuclear Electric plc

Timpson Road

Wythenshawe

Manchester M23 9LL

United Kingdom

\section{ONSITE}

50 Pacific Northwest Laboratory

E. S. Andersen

R. E. Bowey

D. M. Boyd

S. H. Bush

A. A. Diaz.

S. R. Doctor (18)

J. R. Friley

B. F. Gore (5)

M. S. Grecnwood

R. V. Harris

P. G. Heasler

R. J. Kurtz

F. A. Simonen (5)

J. C. Spanner

T. V. Vo (5)

Publishing Coordination

Technical Report Files (5) 


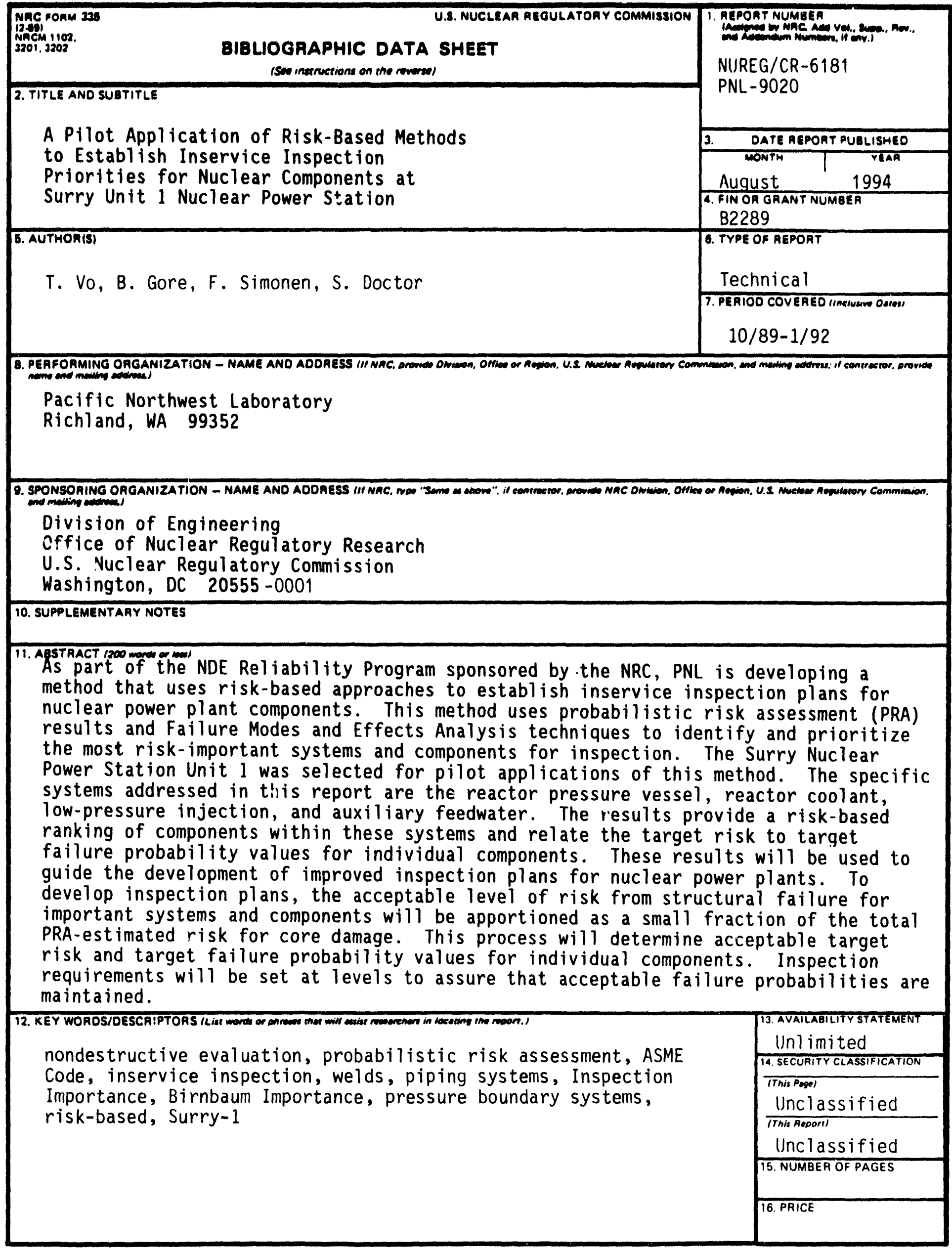



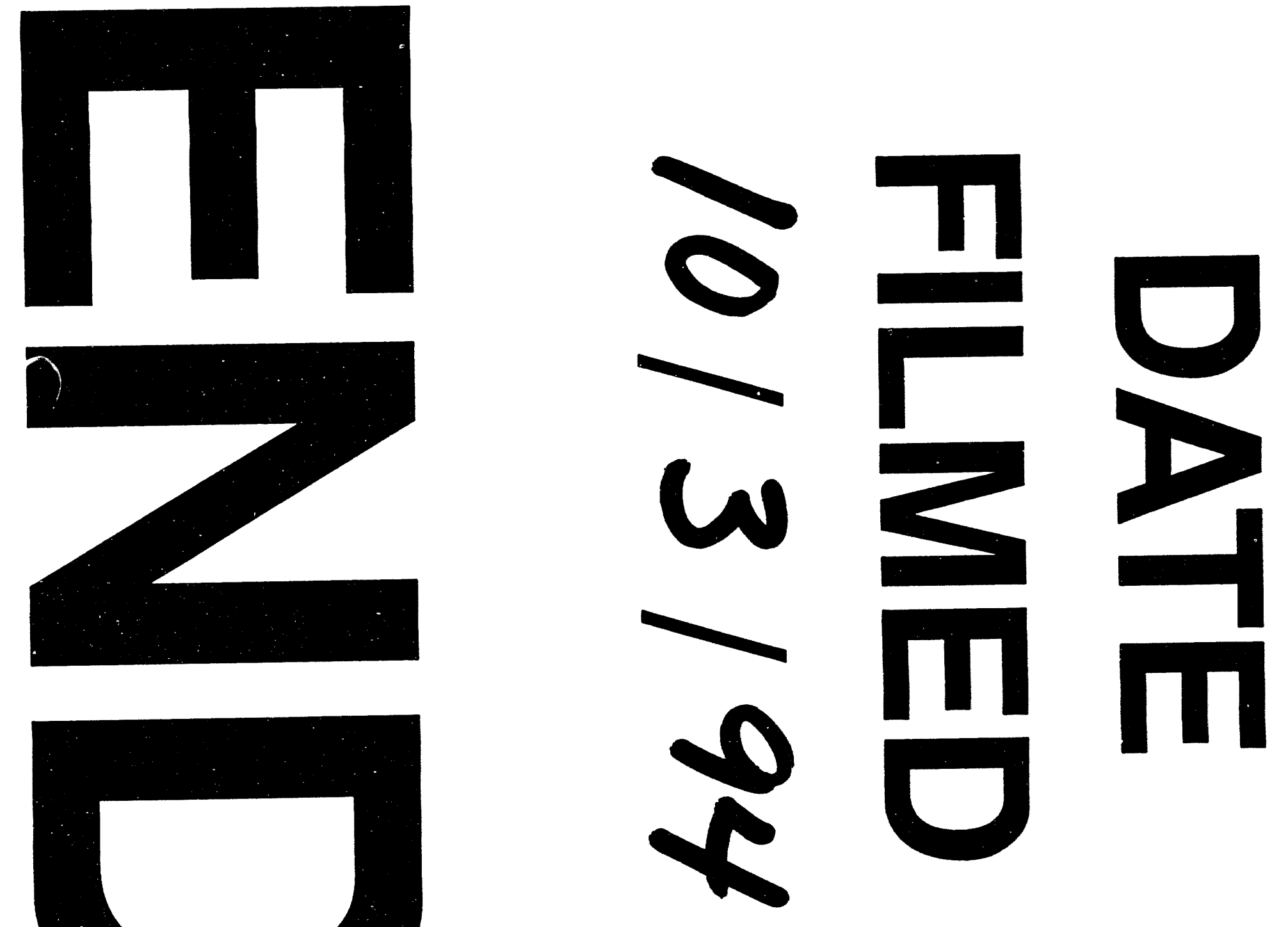